DANIEL GONÇALVES BRUNO

Efeito de um fito composto no desempenho de leitões submetidos ao desafio experimental com Salmonella typhimurium 


\title{
Efeito de um fito composto no desempenho de leitões submetidos ao desafio experimental com Salmonella
}

\author{
typhimurium
}

Dissertação apresentada ao Programa de Pós-Graduação em Nutrição e Produção Animal da Faculdade de Medicina Veterinária e Zootecnia da Universidade de São Paulo para a obtenção do Titulo de Mestre em Medicina Veterinária

Departamento:

Nutrição e Produção Animal

Área de concentração:

Nutrição e Produção Animal

Orientador:

Prof. Dr. Aníbal de Sant'Anna Moretti

Pirassununga 
Autorizo a reprodução parcial ou total desta obra, para fins acadêmicos, desde que citada a fonte.

DADOS INTERNACIONAIS DE CATALOGAÇÃO-NA-PUBLICAÇÃO

(Biblioteca Virginie Buff D’Ápice da Faculdade de Medicina Veterinária e Zootecnia da Universidade de São Paulo)

T.1995

Bruno, Daniel Gonçalves

FMVZ Efeito de um fito composto no desempenho de leitões Daniel Gonçalves Bruno. - Pirassununga: D. G. Bruno, 2008.

$137 \mathrm{f.}:$ il.

Dissertação (mestrado) - Universidade de São Paulo. Faculdade de Medicina Veterinária e Zootecnia. Departamento de Nutrição e Produção Animal, 2008.

Programa de Pós-Graduação: Nutrição e Produção Animal.

Área de concentração: Nutrição e Produção Animal.

Orientador: Prof. Dr. Aníbal de Sant'Anna Moretti.

1. Ganho compensatório. 2. Promotor de crescimento. 3. Oxidação lipídica. 4. Histopatologia. I. Título. 


\section{UNIVERSIDADE DE SÃO PAULO}

Faculdade de Medicina Veterinária e Zootecnia

Comissão Bioética

\section{CERTIFICADO}

Certificamos que o Projeto intitulado "Avaliação de um fito composto em leitões na fase de creche submetidos a desafio com salmonella tiphimurium", protocolado sob o n¹228/2007, utilizando 124 (cento e vinte quatro) suínos, sob a responsabilidade do Prof. Dr. Aníbal de Sant'Anna Moretti, está de acordo com os princípios éticos de experimentação animal da Comissão de Bioética da Faculdade de Medicina Veterinária e Zootecnia da Universidade de São Paulo e foi aprovado em reunião de 21/11/07.

We certify that the Research "Evaluation of a phyto-compound in nursery piglets submitted to salmonella tiphimurium challenge", protocol number 1228/2007, utilizing 124 (one hundred twenty four) swine, under the responsibility Prof. Dr. Anibal de Sant'Anna Moretti, agree with Ethical Principles in Animal Research adopted by Bioethic Commission of the School of Veterinary Medicine and Animal Science of University of São Paulo and was approved in the meeting of day $11 / 21 / 07$.

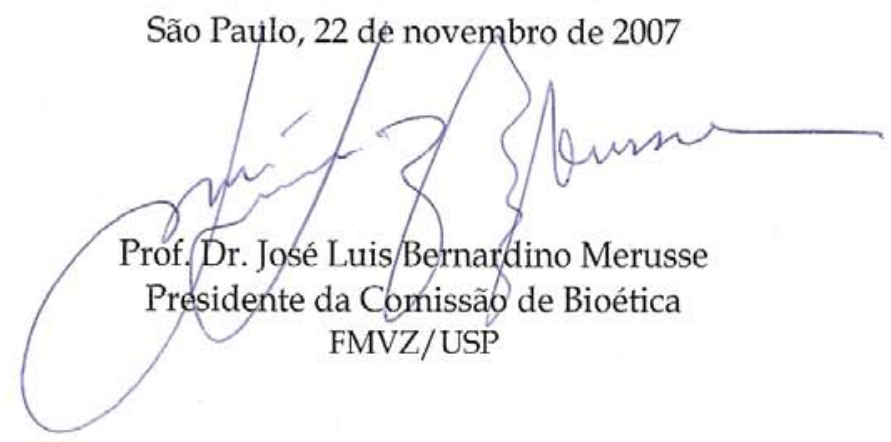

Av. Prof. Dr. Orlando Marques de Paiva, $n^{\circ} 87$ - 05508-270 - Cidade Universitária "Armando de Salles Oliveira". Fax: (11) 3032-2224 - fones: (11) 309107676/7671 - e-mail: fmvz@edu.usp.br 


\section{FOLHA DE AVALIAÇÃO}

Nome: BRUNO, Daniel Gonçalves

Título: Efeito de um fito composto no desempenho de leitões submetidos ao desafio experimental com Salmonella typhimurium

Dissertação apresentada ao Programa de Pós-Graduação em Nutrição e Produção Animal da Faculdade de Medicina Veterinária e Zootecnia da Universidade de São Paulo para a obtenção do Titulo de Mestre em Medicina Veterinária

Data:

1

Banca Examinadora

Prof. Dr.: Instituição:

Assinatura: Julgamento:

Prof. Dr.: Instituição:

Assinatura: Julgamento:

Prof. Dr.: Instituição:

Assinatura: Julgamento: 


\section{DEDICATÓRIA}

Aos meus pais, Gerson e Carolina, e aos meus avós, Isabel e Manoel; devo tudo a vocês.

Ao meu tio, Geraldo Gonçalves Bruno (in memorian), e todos os momentos de risos e alegria que ele nos proporcionou. 


\section{AGRADECIMENTO}

Ao meu amigo, Prof. Aníbal de Sant'Anna Moretti, meu orientador, por todos os ensinamentos, orientação, companheirismo, pela confiança em mim depositada, e principalmente, por me ensinar que nossos sonhos nunca são impossíveis, por mais absurdo que pareçam. A toda equipe LPS, tanto aos "titulares" (Carol, Clélia, Foca, Francine, Larissa, Octávio, Simone, Simprão) quanto aos "aspirantes" (Bianca, Bruna, Estér): nunca conseguiria nada sem vocês. Gostaria também de fazer um agradecimento especial aos veterinários Abrão, Edison, Marcos e Wagner, o "braço no campo" do LPS, exemplos de dedicação e competência profissional, e também ao Fábio Zanquetin e Eduardo Scheffer, por toda a dedicação e tudo que aprendi com vocês.

A toda minha família: a meus pais (Gerson e Carolina), irmãos (Levi, Lígia e Gabriela), meus tios (Cida, Sílvia, Cipriano e Rita), a todos meus incontáveis primos, e em especial, a meus avós (Isabel e Manoel), que me apoiaram durante toda a graduação. À Bunny, Mel e Tica.

A todos os professores desta casa, em especial aos Prof. Ricardo Albuquerque, Maria de Fátima, Simone, Messias, Angélica e Paulo Mazza. Também aos Profs. Andréa (VPS), Rubens (VRA), Marcelo C. Cezar, Lúcio Araújo, Flávio Meirelles (FZEA). Ao Prof. Franco (UNIP), pelo excelente trabalho quanto às análises histológicas. Aos meus colegas da pós, em especial ao William, Rafael, Fábian, Vinícius, Aryana, Brunããão, Riquelme, Rodrigo Tenente, Pasqual, Milton, Agostinho, Carolzinha, Carol Tobias, Gaúcho, Valter, Tenébrio, Culhão, Martini, Valesca, Cris, Ana Flávia, Paulinha, Bruna, Érica, Diegón, Doug, Juliana, Michele,

Felipe Onofre Borges, Barbosa, Raquel, Xeila e aos Papas da Nutrição (Zé Ésler, Léo e Jefferson). À Estela Kobashigawa, por tudo de bom que passamos juntos. 
Aos funcionários do VNP, especialmente Alessandra, Cris, Ari, Simi, Zeca, Zequinha, Gilson, Lú, Lourdes, Ogna, Júnior. Ao pessoal da guarda (Sebastião, Almeida, Alberto, Luciano, Adriano e Miltinho) e do Lótus (Maria, Claudimara, Nice, Cecília). Ao pessoal do setor de apoio da FMVZ-USP (Limarque, Reinaldo, Marcão, Bigode). Aos funcionários da Biblioteca da FMVZ-USP, principalmente a Helena e Elza. Aos motoristas da PCAPS, Wagnão, Ari, Estevez. Aos funcionários do frigorífico da PCAPS-USP. Um agradecimento especial à Giovanna (Morfofisiologia Molecular e Desenvolvimento - LMMD) e Mirele (Laboratório de Neurociência e Proteômica). Ao Paulo Micheloni, sem o qual esse trabalho nunca teria sido realizado. À Granja Santa Rosa, em especial ao Pedro Gaboni e ao Fernando). À A/C Agroindustrial, principalmente ao Danilo Coruzzi. A todos da Granja Rica (Itu, $\mathrm{SP}$ ), onde fiz preciosas amizades, e ao veterinário Joamar (Vitagri), que me propiciou a oportunidade de estagiar lá. À Tânia e Amélia, da zeladoria da PCAPS.

Aos meus amigos Éder, Vaguinho e Gisele, ligados eternamente à minha alma. À Simone, por todos os momentos de felicidade, e ao Dudu, brotinho de luz e esperança para esse mundo.

I wish also to thank Mr. Dritz (Kansas University, USA), Mr. Caspar Wenk (Institute of Animal Sciences, Switzerland) and Mr. Bampidis (Animal Research Institute, Greece), who helped me a lot by patiently reading my e-mails and sending me back precious papers.

Aos meus amigos de graduação, Lombardi, Gaugo, Flan, Ponstan, Artefato, Traveko, Febén, Askáris, Mucina, Pacu, Azaléias, Milena, Arine, Muzzarela, Cris, Tiamat, Furunkulu, Puara, Varicela, Mituca, Kanú, Hebe, Signal e Millhouse. Aos meus amigos de Matão, Vitão, Valfrido, Célinho, Fernandinho, Chibóca, Camila, Carol, Morto, Motor, Marião, Guilherme Forrinho, Toshiu, Barnabé, Maísa. Aos meus 
amigos de Videira, Giancarlo, Everson, Marli, Alcir e Cristina.

À Fundação de Amparo ao Pesquisador do Estado de São Paulo (FAPESP), pelo amparo financeiro para realização do projeto, e pela bolsa.

Aos alunos de graduação do grupo de estudos de suinocultura das turmas 71 e 72, minhas "cobaias" na atividade docente. Creio que vocês ensinaram mais a mim que eu a vocês.

Ao Prof. Palermo (VPT-USP), pois muito de minha vida profissional devo a você. A toda equipe técnica de suinocultura e avicultura (Perdigão S/A, Videira, SC); à equipe da Granja São Roque (Videira, SC), em especial ao Nelson, Salete, Saletinha, Marli, Cléber, Algacir, Biau e ao pessoal do CDG (Coca, Clair Würges, Elisangêla, Tati e Maria).

MUITO OBRIGADO !!!!!!!!!!! 
"Que teu alimento seja teu remédio e que teu remédio seja teu alimento" Hippocrates, 400 A.C., sobre as plantas medicinais 


\section{RESUMO}

BRUNO, D. G. Efeito de um fito composto no desempenho de leitões submetidos ao desafio experimental com Salmonella typhimurium. [Effect of a phyto compound on the performance of piglets challeged with Salmonella typhimurium]. 2008. 137 f. Dissertação (Mestrado em Medicina Veterinária) - Faculdade de Medicina Veterinária e Zootecnia, Universidade de São Paulo, Pirassununga, 2008.

Apesar da eficácia dos antimicrobianos como melhoradores no desempenho animal, questões relativas à seleção de microorganismos resistentes e transferência desses para o consumo humano de carne vêem trazendo uma crescente preocupação que tem provocado diminuição do seu uso. Assim, há necessidade da busca de alternativas, destacando-se as ervas medicinais, as quais apresentam ações, antimicrobiana, antioxidante, imunomodulatória e ainda, estimulante da secreção de enzimas digestivas. O objetivo do estudo foi avaliar a ação de um fito composto, produzido pela adição de partes aéreas secas e trituradas de plantas medicinais (Rosmarinus officinalis, Mentha piperita, Lippia sidoides e Lychnophora pinaster), em leitões, desde a creche até o abate, sobre parâmetros de desempenho, freqüência de diarréia, eliminação fecal de salmonelas, lesões histopatológicas intestinais e oxidação lipídica da carcaça. Os animais foram submetidos a duas situações: uma de desafio experimental $(\mathrm{D}$, com inoculação de Salmonella typhimurium aos 35 dias de idade) e outra sem desafio (SD), permanecendo ambos grupos em salas isoladas. O delineamento experimental foi inteiramente casualizado, com arranjo fatorial $3 \times 2$, sendo um fator o desafio, e outro, a suplementação de aditivos na ração (fito composto - FITO; antibióticos- ATB; e controle negativo, sem adição de promotores - CTRL). Foram alojados 120 leitões recém-desmamados aos 21 dias de idade, na unidade de creche do Laboratório de Pesquisa em Suínos. Os animais foram pesados aos 21, 35, 49, 63 dias (creche) aos 96 e 106 dias (crescimento) e 131 dias de idade (terminação), e verificado o consumo de ração. Foi avaliada a freqüência de dias com diarréia (FDD) na creche, além da eliminação fecal de $S$. typhimurium, observando-se lesões histopatológicas causadas pela bactéria no trato entérico, e oxidação lipídica da carcaça aos 131 dias de idade. Não houve interação entre aditivos e desafio para nenhuma variável estudada. O peso médio (PM) do 
grupo ATB foi mais elevado durante todos os períodos em relação a FITO e CTRL, e estes não diferiram entre si; no entanto, aos 96 e 106 dias, o PM dos animais CTRL foi maior que FITO. De 21 a 35 dias de idade, a conversão alimentar (CA) do grupo ATB foi significativamente menor que CTRL; no entanto, FITO promoveu valor intermediário, não diferindo estatisticamente de ambos. O desafio experimental levou à queda no consumo diário de ração (CDR) de 35 a 48 dias. No entanto, no período final de crescimento, houve um efeito compensatório sobre as variáveis de desempenho, sendo PM, ganho diário de peso (GDP), CDR e CA significativamente melhores na sala $D$. Ainda, nesse período, na sala $D$, todas essas variáveis foram melhores para FITO, apesar da diferença ser meramente numérica, sugerindo efeito compensatório desse aditivo. O ATB promoveu menor FDD dos 21 aos 48 dias; no entanto, dos 35 aos 48 dias, FITO promoveu uma melhora mais rápida no quadro que CTRL. Não houve influência dos aditivos sobre a eliminação fecal de salmonelas, lesões histopatológicas no trato entérico ou sobre a oxidação lipídica na carcaça. Assim, a melhor CA na creche, e o efeito compensatório no final da fase de crescimento justificam futuras pesquisas sobre a ação do produto.

Palavras-chave: Ganho compensatório. Promotor de crescimento. Oxidação lipídica. Histopatologia. 


\section{ASTRACT}

BRUNO, D. G. Effect of a phyto compound on the performance of piglets challeged with Salmonella typhimurium. [Efeito de um fito composto no desempenho de leitões submetidos ao desafio experimental com Salmonella typhimurium]. 2008. 137 f. Dissertação (Mestrado em Medicina Veterinária) Faculdade de Medicina Veterinária e Zootecnia, Universidade de São Paulo, Pirassununga, 2008.

Despite the proven efficiency of antibiotics as growth promoters, issues associated to selection of microbial resistance and its impact over human health are rising concern between consumers and decreasing their use. Therefore, alternatives must be found, and medical herbs, with antimicrobial, antioxidant, immunomodulatory and stimulatory of digestives enzymes properties, seem promising. This study was carried out in order to evaluate the action of a phyogenic compound of medical herbs (Rosmarinus officinalis, Mentha piperita, Lippia sidoides and Lychnophora pinaster) towards piglets from weaning to slaughter, on performance parameters (body weight - BW; average daily gain - ADG; average daily feed intake - ADFI; and feed conversion - FC), frequency of diarrhea, fecal shedding of salmonellas, gut hystopatological lesions and lipid oxidation of meat, either under a challenged condition (C) or a non-challenged condition (NC). Experimental challenge consisted of oral administration of Salmonella typhimurium to piglets, at 35 days of age. Both groups were kept in isolated rooms. Experimental design was at random, and the treatments distributed in a $3 \times 2$ factorial arrangement. Factors were: challenge $(C$ and NC) and additives (phytogenic compound - PHYTO; antibiotic - ATB; and control CTRL). 120 weaned piglets (21 days years old) were housed at nursery unit of Laboratory of Researche in Swine (LPS), and weighted at 21, 35, 49, 63 (nursery), 96, 105 (growing) and 131 (finishing) days of age. There was not interaction between factors. BW of ATB group was higher througout the experimental period. From 21 to 35 days of age, FC of ATB group was significantly lower than CTRL; however, PHYTO showed intermediary value, which did not statistically differ from both ATB and CTRL. Challenge caused lower ADFI from day 35 to 48 . Nevertheless, at the final of growing period (96 to 105 days of age), there was a compensatory effect on performance, and animals out of $C$ room had showed better values of BW, ADG, ADFI, FC than NC. At C room, such parameters were better for animals out of 
PHYTO group (although the differences were merely numerical), suggesting thus a compensatory effect of this compound. ATB has lead to lower FDD from day 21 to 48; however, from day 35 to 48, FDD of PHYTO group was lower than CTRL. There was not effect of additives on fecal shedding of salmonellas and on lipd oxidation of carcass. Further studies on the effect of the phyto compound must be carried out, especially during the growing and finishing periods.

Key words: Compensatory growth. Growth promoter. Lipid oxidation. Hystopatology. 


\section{LISTA DE TABELAS}

Tabela 1 - Composição em quilogramas das rações experimentais administradas durante 0 período de creche.

Tabela 2 - Composição bromatológica calculada das rações préinicial, inicial 1 e inicial 2

Tabela 3 - Composição em quilogramas das rações experimentais administradas durante $\mathrm{o}$ período de crescimento $\mathrm{e}$ terminação

Tabela 4 - Composição bromatológica calculada das rações crescimento e terminação

Tabela 5 - Média das temperaturas mínimas e máximas, e da amplitude de temperatura em diferentes semanas $\left(\mathrm{em}^{\circ} \mathrm{C}\right)$

Tabela 6 - Valores médios e desvios padrão da variável peso médio (PM), em quilogramas, de leitões dos 21 aos 34,35 aos 48, 49 aos 63 e 21 aos 63 dias de idade, recebendo na dieta fito composto (FITO), antibiótico (ATB) ou sem aditivo algum na dieta (CTRL), nas salas desafiadas (D) ou não desafiadas (SD).

Tabela 7 - Valores médios e desvios padrão da variável peso médio (PM), em quilogramas, de leitões aos 63, 96, 106 e 131 dias de idade, recebendo na dieta fito composto (FITO), antibiótico (ATB) ou sem aditivo algum na dieta (CTRL), nas salas desafiadas (D) ou não desafiadas (SD)

Tabela 8 - Valores médios dos pesos médios (PM), expressos em quilogramas, e respectivos coeficientes de variação (CV), expressos em porcentagem, dos leitões aos 49 e 63 dias de idade, nos tratamentos fito composto (FITO), antibiótico (ATB) e controle (CTRL), nas salas desafiada e não desafiada

Tabela 9 - Valores médios e desvios padrão da variável ganho diário de peso (GDP), em quilogramas/animal/dia, de leitões dos 21 aos 34,35 aos 48,49 aos 63 e 21 aos 63 dias de idade, recebendo na dieta fito composto (FITO), antibiótico (ATB) ou sem aditivo algum na dieta (CTRL), nas salas desafiadas (D) ou não desafiadas (SD) 
Tabela 10 - Valores médios e desvios padrão da variável ganho diário de peso (GDP), em quilogramas/animal/dia, de leitões dos 63 aos 95, 96 aos 105, 106 aos 131 e 63 aos 131 dias de idade, recebendo na dieta fito composto (FITO), antibiótico (ATB) ou sem aditivo algum na dieta (CTRL), nas salas desafiadas (D) ou não desafiadas (SD)

Tabela 11 - Valores médios e desvios padrão da variável consumo diário de ração (CDR), em quilogramas/animal/dia, de leitões dos 21 aos 34, 35 aos 48, 49 aos 63 e 21 aos 63 dias de idade, recebendo na dieta fito composto (FITO), antibiótico (ATB) ou sem aditivo algum na dieta (CTRL), nas salas desafiadas (D) ou não desafiadas (SD)

Tabela 12 - Valores médios e desvios padrão da variável consumo diário de ração (CDR), em quilogramas/animal/dia, de leitões dos 63 aos 95, 96 aos 105, 106 aos 131 e 63 aos 131 dias de idade, recebendo na dieta fito composto (FITO), antibiótico (ATB) ou sem aditivo algum na dieta (CTRL), nas salas desafiadas (D) ou não desafiadas (SD).

Tabela 13 - Valores médios e desvios padrão da variável conversão alimentar (CA) de leitões dos 21 aos 34, 35 aos 48, 49 aos 63 e 21 aos 63 dias de idade, recebendo na dieta fito composto (FITO), antibiótico (ATB) ou sem aditivo algum na dieta (CTRL), nas salas desafiadas (D) ou não desafiadas (SD)

Tabela 14 - Valores médios e desvios padrão da variável conversão alimentar (CA) de leitões dos 63 aos 95, 96 aos 105, 106 aos 131 e 63 aos 131 dias de idade, recebendo na dieta fito composto (FITO), antibiótico (ATB) ou sem aditivo algum na dieta (CTRL), nas salas desafiadas (D) ou não desafiadas (SD)

Tabela 15 - Valores médios e desvios padrão das variáveis ganho diário de peso (GDP, em quilogramas/animal/dia), consumo diário de ração (CDR, em quilogramas/animal/dia) e conversão alimentar (CA) de leitões ao final do período de crescimento (96 aos 105), recebendo na dieta fito composto (FITO), antibiótico (ATB) ou sem aditivo algum na dieta (CTRL), nas salas desafiadas (D) ou não desafiadas (SD)

Tabela 16 - Valores médios e coeficiente de variação da freqüência de dias com diarréia (FDD) de leitões dos 21 aos 34, 35 aos 48, 49 aos 63 e 21 aos 63 dias de idade, recebendo na dieta fito composto (FITO), antibiótico (ATB) ou sem aditivo algum na dieta (CTRL), nas salas desafiadas (D) ou não desafiadas (SD). 
Tabela 17 - Valores médios e coeficiente de variação da freqüência de dias com diarréia pastosa (FDDp) de leitões dos 21 aos 34, 35 aos 48, 49 aos 63 e 21 aos 63 dias de idade, recebendo na dieta fito composto (FITO), antibiótico (ATB) ou sem aditivo algum na dieta (CTRL), nas salas desafiadas (D) ou não desafiadas (SD)

Tabela 18 - Valores médios e coeficiente de variação da freqüência de dias com diarréia líquida (FDDI) de leitões dos 21 aos 34, 35 aos 48, 49 aos 63 e 21 aos 63 dias de idade, recebendo na dieta fito composto (FITO), antibiótico (ATB) ou sem aditivo algum na dieta (CTRL), nas salas desafiadas (D) ou não desafiadas (SD)

Tabela 19 - Freqüência observada da presença de Salmonella typhimurium em suabes retais de leitões aos 35, 49 e 63 dias de idade, na sala desafiada (D) e sem desafio (SD)

Tabela 20 - Freqüência observada da presença de Salmonella typhimurium em suabes retais de leitões aos 35, 49 e 63 dias de idade, tratados com fito composto (FITO), antibióticos (ATB) ou que não receberam aditivo na ração (CTRL), na sala desafiada

Tabela 21 - Freqüência observada da presença de Salmonella typhimurium em suabes retais de leitões aos 35, 49 e 63 dias de idade, tratados com fito composto (FITO), antibióticos (ATB) ou que não receberam aditivo na ração (CTRL), na sala não desafiada 108

Tabela 22 - Escore atribuído e respectivo grau de lesão histológica 110

Tabela 23 - Escore médio de cada lesão no íleo, cólon e linfonodo mesentérico nas salas desafiadas (D) e sem desafio (SD), em leitões de 63 dias de idade recebendo o fitocomposto (FITO), antibióticos (ATB) ou não recebendo aditivos (CTRL) na dieta 


\section{LISTA DE FIGURAS}

Figura 1 - Estrutura de uma molécula de fenol ................................................33

Figura 2 - Exemplo de uma molécula de fenilpropanol, o ácido cinâmico

Figura 3 - Exemplo de uma molécula de flavonóide ........................................ 34

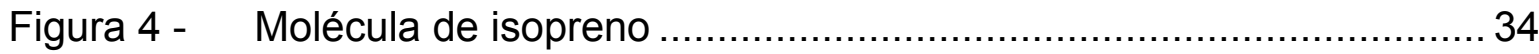

Figura 5 - Intalações de creche do Laboratório de Pesquisa em

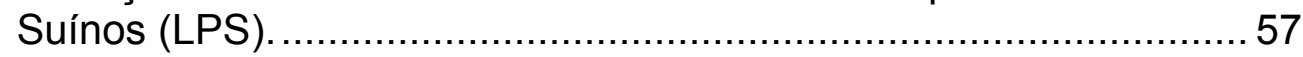

Figura 6 - Leitões alocados na sala sem desafio (SD) ……........................ 57

Figura 7 - Freqüência de dias com diarréia nos leitões nas salas desafiadas (D) e sem desafio (SD), dos 21 aos 34,35 aos 48 e dos 49 aos 63 dias de idade

Figura 8 - Freqüência de dias com diarréia em leitões recebendo na ração fito composto (FITO), antibiótico (ATB) ou sem aditivos (CTRL) dos 21 aos 34, 35 aos 48 e dos 49 aos 63 dias de idade

Figura 9 - Freqüência de dias com diarréia pastosa nos leitões nas salas desafiadas (D) e sem desafio (SD), dos 21 aos 34, 35 aos 48 e dos 49 aos 63 dias de idade

Figura 10 - Freqüência de dias com diarréia pastosa em leitões recebendo na ração fito composto (FITO), antibiótico (ATB) ou sem aditivos (CTRL) dos 21 aos 34,35 aos 48 e dos 49 aos 63 dias de idade

Figura 11 - Freqüência de dias com diarréia líquida nos leitões nas salas desafiadas (D) e sem desafio (SD), dos 21 aos 34, 35 aos 48 e dos 49 aos 63 dias de idade 103

Figura 12 - Freqüência de dias com diarréia líquida em leitões recebendo na ração fito composto (FITO), antibiótico (ATB) ou sem aditivos (CTRL) dos 21 aos 34,35 aos $48 \mathrm{e}$ dos 49 aos 63 dias de idade 104

Figura 13 - Região das criptas no íleo com infiltrado 
predominantemente neutrofílico na lâmina própria

Figura 14 - Cólon com desnudamento do epitélio superficial e manutenção das glândulas. Presença de infiltrado leucocitário moderado em lâmina própria

Figura 15 - Valores médios e desvio-padrão da concentração de malonaldeído ( $\mathrm{mg} / \mathrm{kg}$ de tecido muscular) nos leitões recebendo o fito composto (FITO), antimicrobianos (ATB ) ou não suplementados (CTRL) 


\section{LISTA DE ABREVIATURAS E SIGLAS}

\begin{tabular}{|c|c|}
\hline$\mu g$ & micrograma \\
\hline AGP & glicoproteína $\alpha-1$-ácida \\
\hline ATB & antibiótico \\
\hline ATP & adenosina trifosfato \\
\hline $\mathrm{BHT}$ & butilidróxitolueno \\
\hline CA & conversão alimentar \\
\hline $\mathrm{cal} / \mathrm{g}$ & calorias por grama \\
\hline $\mathrm{CCl}_{4}$ & tetracloreto de carbono \\
\hline CDR & consumo diário de ração \\
\hline CMB & concentração mínima bactericida \\
\hline CMI & concentração mínima inibitória \\
\hline CTRL & controle \\
\hline CV & coeficiente de variação \\
\hline CYP & enzimas do complexo citocromo P450 \\
\hline $\mathrm{D}$ & desafio \\
\hline DPPH & 2,2-difenil-1-picrilidrazila \\
\hline$E$. & Escherichia \\
\hline FDD & freqüência de dias com diarréia \\
\hline FDDI & freqüência de dias com diarréia líquida \\
\hline FDDp & freqüência de dias com diarréia pastosa \\
\hline FITO & fito composto \\
\hline FMVZ & Faculdade de Medicina Veterinária e Zootecnia \\
\hline g & gramas \\
\hline GDP & ganho diário de peso \\
\hline $\mathrm{GH}$ & hormônio de crescimento \\
\hline GST & glutationa S-transferase \\
\hline $\mathrm{h}$ & horas \\
\hline $\mathrm{H}^{+}$ & íon hidrogênio \\
\hline HxE & hematoxilina e eosina \\
\hline IGF-I & fator de crescimento insulina-semelhante 1 \\
\hline IGFBP3 & proteína ligante do fator de crescimento insulina-semelhante 3 \\
\hline IL & interleucina \\
\hline $\mathrm{K}^{+}$ & íon potássio \\
\hline K88 & antígeno capsular 88 \\
\hline $\mathrm{kg}$ & quilograma \\
\hline LP & Lâmina própria \\
\hline
\end{tabular}


LPS Laboratório de Pesquisa em Suínos

LSS Laboratório de Sanidade Suína

M. Mentha

$\mathrm{m}^{2} \quad$ metros quadrados

$\mathrm{mg} / \mathrm{kg} \quad$ miligramas por quilo

$\mathrm{ml} \quad$ mililitros

MSTN miostatina

ns não significativo estatisticamente

O. Oreganum

OMS Organização Mundial de Saúde

PCR reação de cadeia em polimerase

PM peso médio

ppm partes por milhão

PRRSV vírus da síndrome reprodutiva e respiratória suína

PUFA ácidos graxos poli-insaturados

QR $\quad \mathrm{NAD}(\mathrm{P}) \mathrm{H}$ :quinona redutase

R. Rosmarinus

RNAm ácido ribo-nucleíco mensageiro

S. Salmonella

SB Submucosa

SD sem desafio

SLT II Shiga-like II

sp espécie

spp espécies

TBARS substâncias reativas ao ácido tiobarbitúrico

TNF- $\alpha$ fator de necrose tumoral $\alpha$

u.f.c. unidades formadoras de colônia

UGT UDP-glicoronosiltransferase

UI Unidades internacionais

USP Universidade de São Paulo

vs versus

XLT4 xilol-lisina-tergitol 4 


\section{SUMÁRIO}

2 REVISÃO DE LITERATURA

2.1 FISIOLOGIA DIGESTIVA DE LEITÕES RECÉM

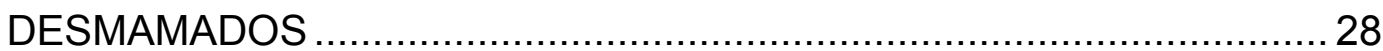

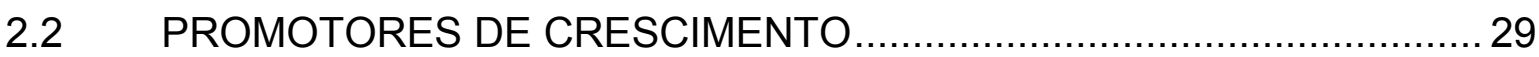

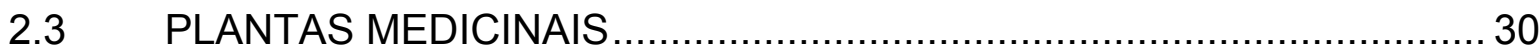

2.3.1 Estrutura química das substâncias presentes nas plantas medicinais 32

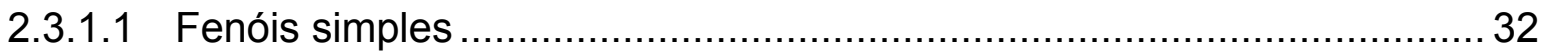

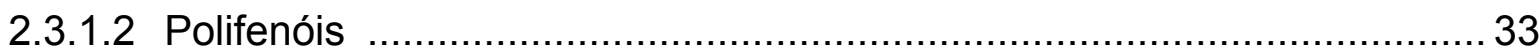

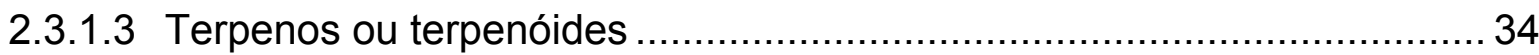

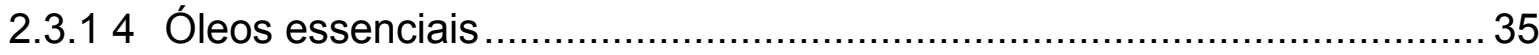

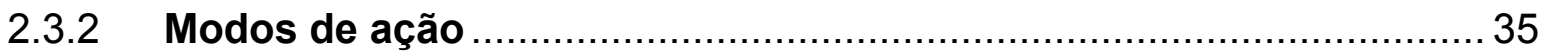

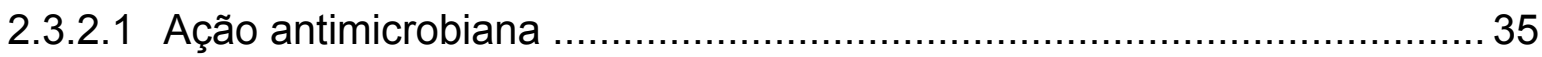

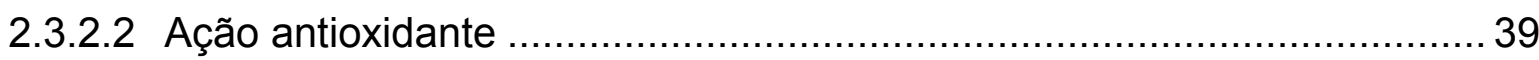

2.3.2.3 Ação colerética, hepatoprotetora e detoxificadora ............................. 40

2.3.2.4 Ação sobre a morfometria do trato gastrointestinal............................. 42

2.3.2.5 Ação sobre a atividade enzimática ................................................ 43

2.3.2.6 Ação sobre o sistema imune .................................................. 44

2.3.3 Ação promotora de crescimento das plantas medicinais ............... 46

2.3.4 Plantas utilizadas no composto: princípios ativos e espectro de ação antimicrobiana 
2.3.4.1 Alecrim (Rosmarinus officinalis) ......................................................... 49

2.3.4.2 Hortelã (Mentha piperita) ……...................................................... 50

2.3.4.3 Alecrim pimenta (Lippia sidoides) …................................................... 51

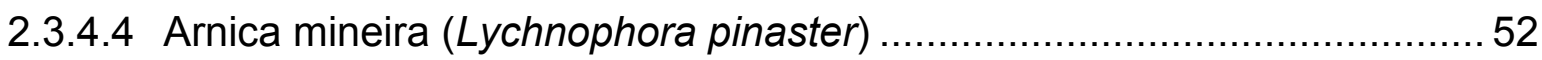

2.4 INOCULAÇÃO EXPERIMENTAL DE PATÓGENOS

ENTÉRICOS: MODELO DE BAIXA HIGIENE NA CRECHE ....................53

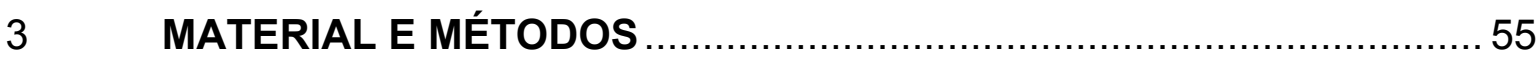

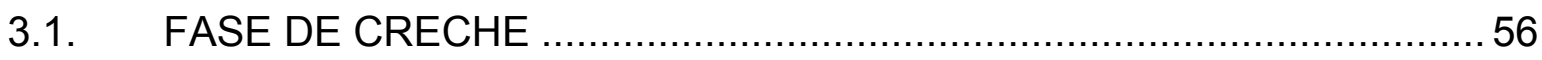

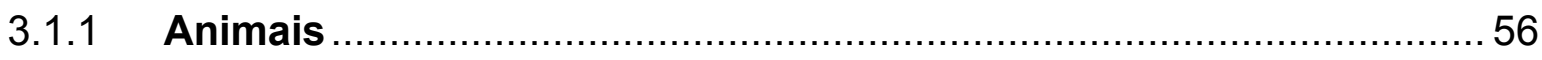

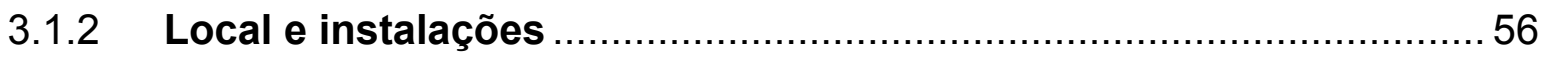

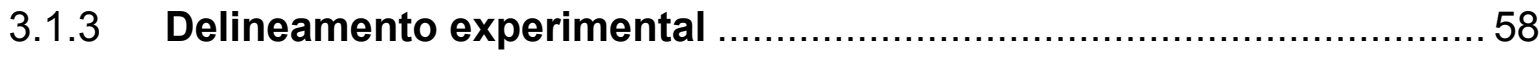

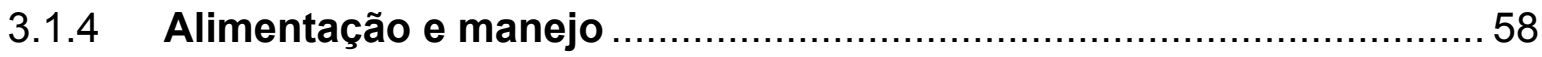

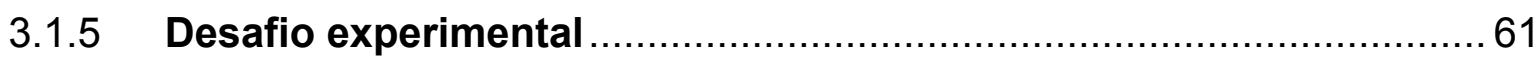

3.1.6 Colheita de materiais e análises laboratoriais ..................................61

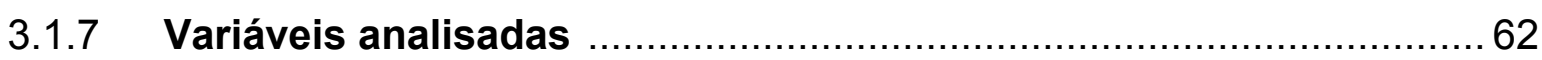

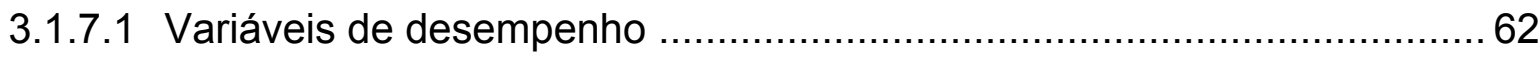

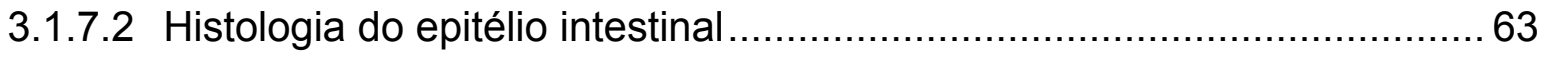

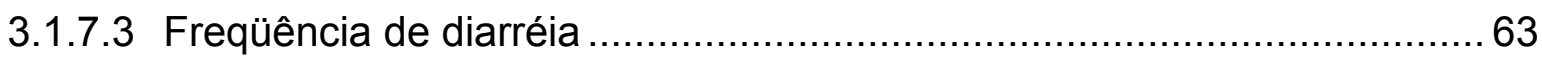

3.1.7.4 Eliminação fecal de Salmonella typhimurium .........................................63

3.2 FASE DE CRESCIMENTO E TERMINAÇÃO .......................................64

3.2.1 Animais, instalações e delineamento experimental ......................... 64

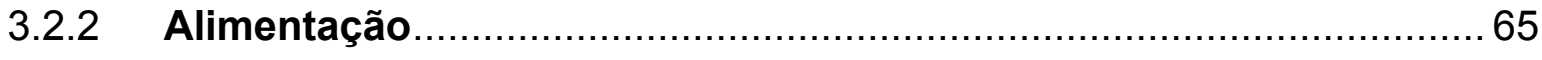

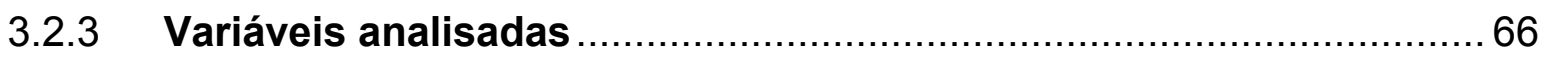

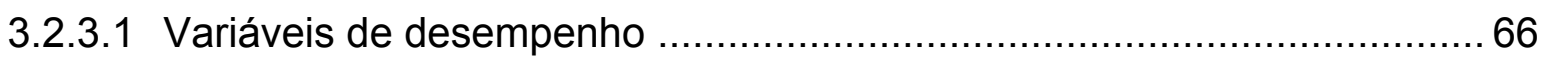

3.2.3.2 Estabilidade oxidativa da gordura intramuscular................................... 67 
3.2.4 Colheita de materiais e análises laboratoriais 67

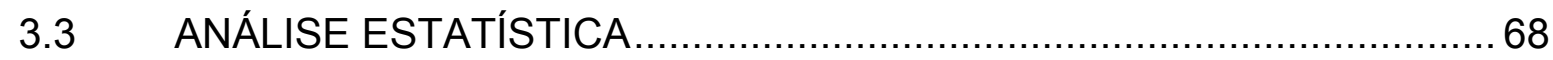

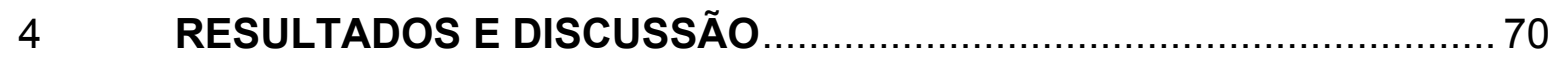

$4.1 \quad$ TEMPERATURA MÉDIA DAS SALAS .............................................. 71

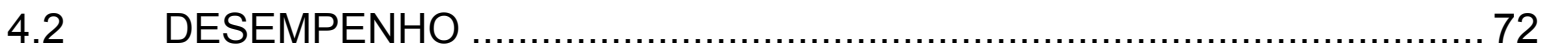

4.2.1 Peso médio

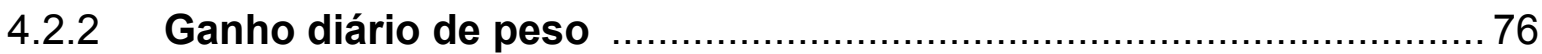

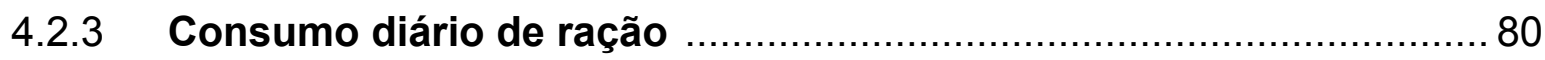

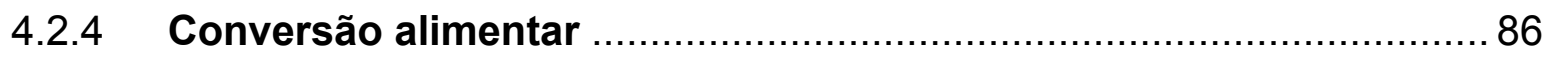

4.2.5 Desempenho durante o período final de crescimento (96

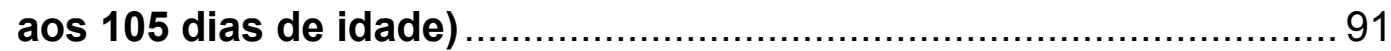

4.3 EVOLUÇÃO DA FREQÜÊNCIA DE DIAS COM DIARRÉIA NA

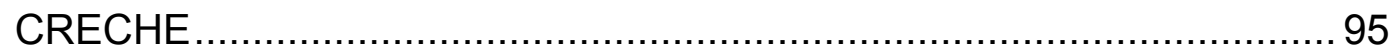

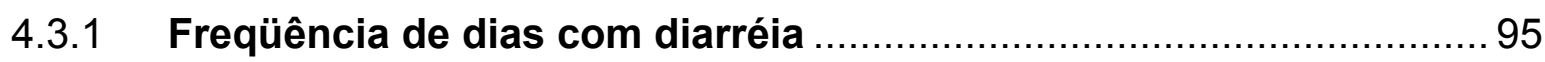

4.3.2 Freqüência de dias com diarréia pastosa ...................................... 98

4.3.3 Freqüência de dias com diarréia líquida .................................... 102

4.4 ELIMINAÇÃO FECAL DE SALMONELLA TYPHIMURIUM .................. 106

4.5 HISTOPATOLOGIA DO TRATO GASTROINTESTINAL ..................... 108

4.6 ESTABILIDADE OXIDATIVA DA GORDURA

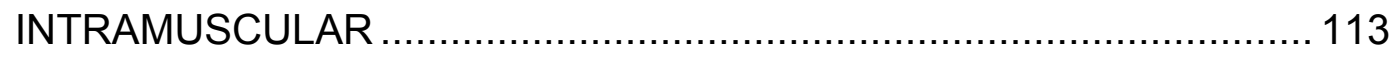

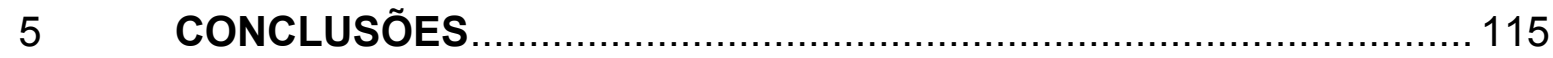

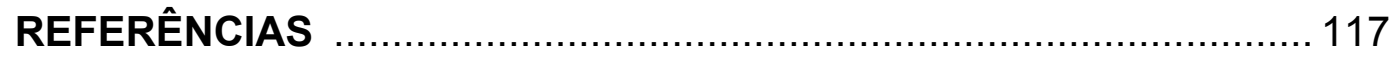


INTRODUÇÃO 


\section{INTRODUÇÃO}

O uso de antibióticos como promotores de crescimento nas rações animais data da década de 50. Algumas questões, no entanto, vêm despertando atenção e ao mesmo tempo preocupação na comunidade científica. Autores acreditam que o uso contínuo de um determinado antibiótico pode induzir a uma pressão de seleção microbiana, levando ao aparecimento de resistência cromossômica (resistência por seleção). Pode haver, ainda, formação de cepas resistentes devido à mutação, do fator $\mathrm{R}$ e do plasmídeo, além da resistência cruzada (resistência contra um grupo inteiro de antibióticos, dado a mecanismo de ação semelhantes). Na maioria dos casos, os microorganismos são multirresistentes (ANDRIGHETTO et al., 1983). Os autores ainda complementam que uma característica das bactérias é sua capacidade de transmitir informações genéticas de um indivíduo para outro, podendo ocorrer a transmissão de resistência a um determinado antibiótico de bactérias da microbiota intestinal que foram selecionadas para bactérias patogênicas. Assim, a veiculação de resíduos de antibióticos através do alimento e a seleção de bactérias patogênicas no trato entérico humano, bem como a própria veiculação de bactérias resistentes (BOERLIN et al., 2001), são fatores que levaram ao banimento dos antibióticos como promotores de crescimento pelos países da Comunidade Européia em janeiro de 2006. Portanto, sendo o Brasil um dos principais exportadores de produtos de origem animal para estes países, há a necessidade de se recorrer a tecnologias alternativas que substituam os antibióticos como agentes promotores de crescimento, e uma delas é a suplementação de aditivos fitogênicos ou produtos à base de ervas medicinais.

Há na literatura, trabalhos que comprovam in vitro, que as ervas medicinais possuem eficiente atividade antibacteriana, antifúngica e até larvicida. Além disso, aumentam a digestibilidade dos alimentos por promoverem aumento na secreção de enzimas no trato digestivo e de bile; alterações histológicas no epitélio intestinal e melhora na resposta imune. São também eficientes agentes antioxidantes, promovendo melhora nas características das carcaças dos animais alimentados com esses compostos (BOTSOGLOU et al., 2002). Somado às vantagens, o custo não mostra-se muito elevado, pois além das plantas serem facilmente cultiváveis, possuem relativa ausência de toxicidade (OLUWATUYI et al., 2004). Assim, as ervas 
medicinais apresentam várias características que justificam sua utilização como possíveis substitutos dos antibióticos na função de promotores de crescimento.

Pelo fato dos princípios ativos das ervas medicinais apresentarem efeito sinérgico entre si, e em virtude da ausência de trabalhos que apontem efeitos antagônicos, seria perfeitamente justificável o uso de mais de uma substância (ou mesmo mais de uma planta) no mesmo composto. Isso também implica na necessidade de menores quantidades de compostos adicionados à ração, diminuindo as alterações sensoriais e consequentemente o risco de rejeição pelos animais.

Por fim, apesar da comprovada ação in vitro dos princípios ativos presentes nas plantas medicinais a serem testadas nesse estudo, faltam pesquisas que comprovem essa eficácia in vivo, através da melhora no desempenho de animais e diminuição da contaminação e da eliminação de bactérias patogênicas, aliado ainda à avaliação de aspectos clínicos, como é proposto nesse trabalho.

O objetivo, portanto, é averiguar os benefícios da inclusão do fito composto constituído por partes aéreas de quatro ervas medicinais sobre o desempenho de leitões recém-desmamados durante a creche, crescimento e terminação, avaliando a ocorrências de diarréia, a ação sobre a eliminação fecal de cepas patogênicas de Salmonella typhimurium e lesões intestinais causada por essa bactéria e a susceptibilidade da carne à oxidação lipídica, em situação de desafio provocado e não provocado. O desafio provocado é caracterizado pela inoculação de uma bactéria, cujo sorotipo é conhecido e preparado para identificação da contagem e lesões. 
REVISÃO DE LITRATURA 


\section{REVISÃO DE LITERATURA}

\subsection{FISIOLOGIA DIGESTIVA DE LEITÕES RECÉM-DESMAMADOS}

O período de desmame (dos 21 aos 28 dias de idade, nos sistemas intensivos de produção de suínos) representa a fase mais crítica na vida dos leitões. É essencial o conhecimento da fisiologia do aparelho digestório dos leitões e os desafios nela inseridos.

Ao contrário do que ocorre naturalmente, onde o desmame é um processo gradual, no desmame artificial as mudanças ocorrem abruptamente. Vários fatores causadores de estresse estão envolvidos, como a separação da mãe, mudança de ambiente, deficiência no controle ambiental, dificuldade de adaptação a comedouros e bebedouros, mistura com leitões de outras leitegadas, brigas para se estabelecer a dominância. Todos esses fatores em conjunto levam a alteração da imunidade e do consumo alimentar, aumentando os riscos para a manifestação de doenças e a consequente diminuição da taxa de crescimento (SOBESTIANSKY et al., 1998).

Outros fatores que tornam a fase de desmama tão crítica aos leitões, segundo Oetting (2005) seriam: mudança de uma dieta líquida para sólida, que leva a alterações do ambiente intestinal $(\mathrm{pH}$, microbiota, suprimento de nutrientes cujas enzimas do trato digestório do leitão ainda não estão sendo produzidas em quantidades suficientemente satisfatórias) e interrupção do suprimento de leite materno, que até então fornecia proteção imune não específica através das imunoglobulinas. Da maior susceptibilidade dos leitões surge as principais doenças, a síndrome da diarréia pós-desmame, causada por determinadas amostras de Escherichia coli (E. coli) produtoras de enterotoxinas e rotavírus e a doença do edema, cujos agentes etiológicos são amostras de E. coli produtoras da toxina SLT II (SOBESTIANSKY et al., 1998). Outros agentes, como a Salmonella thyphimurium e Clostridium spp também podem ocasionar quadros de diarréia nessa fase (UTIYAMA, 2004).

As alterações do ponto de vista social, ambiental, e nutricional decorrentes do desmame resultam em um período crítico de baixa ingestão de alimento, conhecido como anorexia pós-desmame, que ocasionam uma queda transitória na secreção de enzimas digestivas, seguido pela recuperação (MARION et al., 2003), durante o qual 
a digestibilidade e absorção de alimentos encontra-se diminuída. Esse padrão bifásico de secreção enzimática é acompanhado por uma evolução na morfometria das vilosidades do epitélio intestinal, que sofrem uma redução logo após o desmame, se recuperando em seguida. Segundo Nabuurs et al. (1993), a altura das vilosidades atinge um patamar mais baixo entre 3 e 4 dias após o desmame, atingindo os valores pré-desmame novamente entre os dias 11 e 14 após o desmame. Os efeitos da anorexia pós-desmame sobre a secreção de enzimas digestivas e morfometria do epitélio intestinal são multifatoriais, e incluem privação de substratos luminais para o crescimento das células da mucosa epitelial, e redução da expressão de fatores de crescimento para os órgão digestivos, tais como o peptídeo glucagon-semelhante 2, o fator insulina-semelhante I (IGF-I) (STOLL et al., 2000; VENTE-SPREEUWENBERG; BEYNEN, 2003) e a colecistoquinina (MONTAGNE et al., 2007). Assim, a digestbilidade e absorção de nutrientes se encontram diminuídas nessa primeira fase após o desmame. Marion et al. (2003) observaram que, as atividades específicas da tripsina e da lipase no pâncreas diminuíram, respectivamente, em $44 \%$ e $79 \%$ durante a primeira semana após o desmame, bem como as concentrações plasmáticas de gastrina e colecistoquinina, hormônios associados à secreção de enzimas digestivas pelo pâncreas. Hedemann e Jensen (2004) observaram que a tripsina, a carboxipeptidase A, a amilase e a lípase tinham sua atividade específica no pâncreas diminuída até o quinto dia após o desmame.

Por conseguinte, todas essas alterações a que leitões são submetidos no desmame, aliado à falta de maturidade do sistema digestório destes animais frente à nova dieta sólida, causam diminuição na ingestão e absorção dos alimentos, e inevitavelmente, queda no desempenho. Essa queda no desempenho pode repercutir na fase de crescimento e terminação (MAHAN; LEPINE, 1991). Assim, são necessárias tecnologias que amenizem 0 impacto do desmame sobre 0 desempenho do leitão, dentre elas os promotores de crescimento.

\subsection{PROMOTORES DE CRESCIMENTO}

Segundo a Organização Mundial de Saúde (OMS), promotores de crescimento são substâncias que, não sendo nutrientes, são administrados aos 
animais de produção oral ou parenteralmente (SPINOSA et al., 2002), cuja finalidade é a melhora nas taxas de crescimento e/ou conversão alimentar (OETTING, 2005). A utilização destas substâncias na pecuária moderna é essencial, pois as condições intensivas de alojamento nas quais suínos e aves são submetidos atualmente e consequentemente o alto grau de contaminação ambiental faz com que esses animais não expressem todo o potencial genético de produção dessas espécies. Os principais promotores de crescimento usados na produção animal são anabolizantes, agonistas de adrenoceptores $\beta_{2}$, probióticos, prebióticos e principalmente, os antimicrobianos.

Algumas questões relativas ao uso de antimicrobianos como promotores de crescimento vêm despertando preocupação nos consumidores de produtos de origem animal. A influência de resíduos de antimicrobianos biologicamente ativos sobre alterações na microbiota entérica humana adquiridos a partir de carne de animais que receberam essas substâncias via ração, a veiculação de bactérias resistentes a antibióticos, além do aparecimento de resistência bacteriana a antibióticos por bactérias patogênicas no trato gastrointestinal do homem são algumas destas questões (SPINOSA et al., 2002). Threlfall et al. (1996) encontraram fortes indícios de que o uso profilático de antibióticos em bezerros contribuiu para surtos de Salmonella typhimurium DT204/193/20c multirresistente no Reino Unido, no início dos anos 80.

Assim, o uso de antibióticos como promotor de crescimento está sendo gradativamente diminuido, sendo inclusive banido por países da Comunidade Européia. Sendo o Brasil um dos maiores exportadores de produtos de origem animal, alternativas aos antimicrobianos, no caso as ervas medicinais, devem ser consideradas (FUKAYAMA, 2005).

\subsection{PLANTAS MEDICINAIS}

A utilização de extratos vegetais e plantas medicinais com finalidade terapêutica data de milhares de anos, desde a pré-história. Das várias substâncias presentes nas plantas medicinais com propriedades biológicas, as que serão estudadas apresentam: ação antibacteriana (LEAL et al., 2003; GIRÃO et al., 2003; OLUWATUYI et al., 2004), antioxidante (AL-SEREITI et al., 1999), antifúngicas 
(MIMICA-DUKÏC et al., 2003; BOYRAZ; ÖZCAN, 2005; MORENO et al., 2006), antiviral (COWAN, 1999) anticarcinogênica (LEAL, 2003; ESTÉVEZ et al., 2005; SAMARTH et al., 2006), colerética (HOEFLER et al., 1987), hepatoprotetora (HOEFLER et al., 1987), larvicida (CARVALHO et al., 2003), e de estímulo a atividade enzimática (DEBERSAC et al., 2001; OETTING, 2005). Além dessa amplitude de ação, outra razão que justifica o estudo desses compostos como agentes promotores de crescimento como alternativa aos antibióticos, é seu baixo custo e sua relativa ausência de toxicidade (OLUWATUYI et al., 2004); no entanto, mais estudos necessitam ser feitos relacionados a ação tóxica, uma vez que autores identificaram substâncias tóxicas em plantas medicinais, tais como alcalóides pirrolizidínicos, tropânicos, piperínicos e piperidínicos; glico-alcalóides esterólicos; glicosídeos cardiotônicos, cianogênicos e antraquinônicos (ABREU MATTOS, 2000).

Os princípios ativos dos vegetais são moléculas de baixo peso molecular, oriundas do metabolismo secundário das plantas, produzidas como resposta ao estresse fisiológico sofrido por essas plantas, fatores ambientais (variações climáticas, por exemplo) e proteção contra predadores e patógenos (OETTING, 2005). Desse modo, a mesma espécie de planta pode apresentar diferentes substâncias de acordo com a região e condições climáticas, fenômeno esse conhecido por polimorfismo químico (PENGELLY, 2004).

Pesquisas recentes têm demonstrado a existência de efeito sinérgico entre os princípios ativos primários e secundários das plantas, de modo que esses últimos, encontrados em menor concentração, atuariam como potencializadores dos primários (UTIYAMA, 2004). Lambert et al. (2001) verificaram a ação conjunta de dois princípios ativos do orégano (Origanum vulgare), concluindo que houve ação aditiva entre dois de seus princípios ativos, o timol e o carvacrol. Lin et al. (2004); Nascimento et al. (2000) e Iscan et al. (2002) também demonstraram ação aditiva de princípios ativos de fito compostos. Debersac et al. (2001) observaram que há efeito sinérgico entre as várias substâncias presentes em extratos vegetais também na atuação dessas substâncias sobre as enzimas detoxificadoras do fígado, o que ocorre talvez devido ao aumento da estabilidade que compostos secundários presentes nesses extratos conferem aos princípios ativos. Portanto, conclui-se que produtos a base de extratos vegetais devem conter diferentes princípios ativos, e de diferentes plantas, para acentuar o efeito desses. Inclusive, alguns trabalhos citados por Oetting (2005) recomendam que, para melhora dos resultados, devem ser 
administrados combinações de óleos essenciais de diferentes plantas.

Não há na literatura trabalhos que indiquem efeito antagônico entre os princípios ativos dos fito compostos. A importância em se conhecer o dimensão do sinergismo entre os componentes dos fito compostos, está em tentar-se diminuir a quantidade deles para se obter o mesmo efeito, o que implica em menores alterações no sabor das rações, que altas quantidades desses compostos possam acarretar.

\subsubsection{Estrutura química das substâncias presentes nas plantas medicinais}

Segundo Cowan (1999), os principais compostos com ação antimicrobiana das plantas medicinais podem ser agrupados nas seguintes classes: fenólicos (fenóis simples, ácidos fenólicos, quinonas, flavonóides, flavonas, taninos); terpenóides (componentes de uma das frações das plantas medicinais, denominada de óleo essencial); alcalóides, lecitinas, polipeptídeos e poliacetilenos.

\subsubsection{Fenóis simples}

São álcoois aromáticos, cuja molécula é estruturalmente formada por um grupo hidroxila ligado a um anel benzeno, conforme representado na figura 1. Dentro dessa classe, temos os fenilpropanóides, que são constituídos por um anel benzeno aderido a uma cadeia com 3 carbonos, conforme a figura 2 (PENGELLY, 2004). 


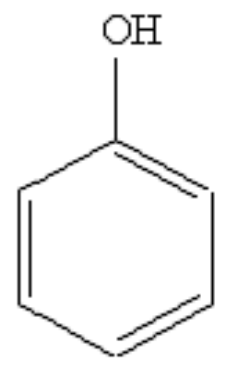

Figura 1 - Estrutura de uma molécula de fenol

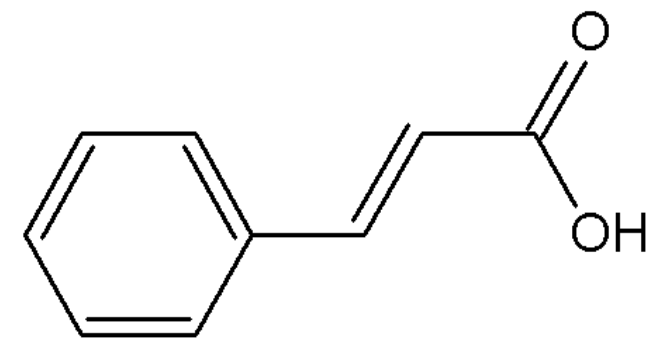

Figura 2 - Exemplo de uma molécula de fenilpropanol, o ácido cinâmico

\subsubsection{Polifenóis}

São constituídos pelos taninos e flavonóides. Os taninos, maior grupo dentro dos polifenóis, têm a capacidade de aderir à proteínas, precipitando-as em complexos insolúveis. São compostos com grande peso molecular, contendo agrupamentos fenóis suficientes para se ligarem a diversas enzimas, inibindo-as. Os flavonóides, por sua vez, possuem um esqueleto com 15 carbonos, formado por dois anéis benzenos conectados a uma cadeia de três carbonos, conforme mostrado na figura 3 (PENGELLY, 2004). 
<smiles>Oc1cc(O)c2c(c1)O[C@H](c1ccc(O)c(O)c1)[C@H](O)C2</smiles>

Figura 3 - Exemplo de uma molécula de flavonóide

\subsubsection{Terpenos ou terpenóides}

Essas substâncias têm como estrutura química geral $\mathrm{C}_{10} \mathrm{H}_{16}$ (monoterpenos), ocorrerendo também como diterpenos, triterpenos, tetraterpenos, hemiterpenos e sesquiterpenos (respectivamente $\mathrm{C}_{20}, \mathrm{C}_{30}, \mathrm{C}_{40}, \mathrm{C}_{5}$ e $\mathrm{C}_{15}$ ). Quando esses compostos possuem em sua molécula oxigênio, recebem a denominação de terpenóides. Especula-se que o mecanismo de toxicidade aos microorganismos envolva 0 rompimento das membranas dos microorganismos (COWAN, 1999).

Os terpenos podem ser subdivididos em uma estrutura com 5 átomos de carbono e 2 ligações insaturadas, denominada isopreno ou hemiterpeno (Figura 4), que por sua vez é sintetizada a partir do acetato em uma via metabólica das plantas denominada via do ácido mevalônico. As moléculas de isopreno se ligam uma após a outra, formando estruturas lineares que de acordo com o número de carbonos recebem a classificação mostrada anteriormente (DEWICK, 1998).

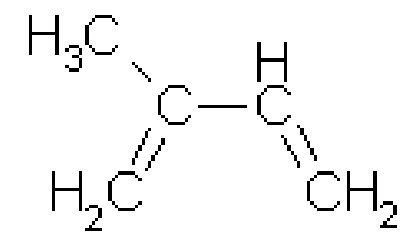

Figura 4 - Molécula de isopreno

Os monoterpenos são a principal substância presente nos óleos essenciais, os quais serão melhor descritos no próximo item. Os diterpenos são compostos com gosto amargo, e tendem a estar mais presentes em plantas da família Lamiaceae. 
Essa propriedade sensorial pode levar a melhora no consumo pelos animais, pois estimulam receptores nervosos gustativos presentes na língua dos animais, levando a aumento na salivação e secreção de suco gástrico (PENGELLY, 2004).

\subsubsection{4 Óleos essenciais}

Óleos essenciais são uma mistura natural complexa de metabólicos secundários voláteis, isolados das plantas por processos de destilação a vapor (OETTING, 2005). O termo essencial vem do fato destas substâncias conferirem à planta propriedades biológicas e serem responsáveis por seu aroma e fragrância, ou seja, a sua "essência" (SCHÖNE et al., 2006). Estas possuem característica lipofílica, sendo solúveis em gorduras e álcoois; são prontamente rancificados e oxidados, quando expostos à luz (PENGELLY, 2004). A ação antimicrobiana dessa fração já está bem estabelecida na literatura (ACAMOVIC; BROOKER, 2005).

A quantidade total de óleos essenciais presentes em uma planta é em geral baixa $(<1 \%)$, no entanto apresentam uma potente atividade terapêutica, que em geral é originada não por um componente apenas, mas sim por uma combinação deles (muitos óleos possuem mais de 50 compostos, os quais geralmente são identificados através de cromatografia ou espectrometria de massa, sendo os principais os terpenos, principalmente os monoterpenos, e os fenilpropanóides). Os terpenos podem ser agrupados nas seguintes subclasses ou famílias, de acordo com o grupo funcional presente em sua molécula: hidrocarbonetos, álcoois, aldeídos, aldeídos cíclicos, cetonas, fenois, éteres, éteres fenólicos, óxidos ou ésteres (PENGELLY, 2004).

\subsubsection{Modos de ação}

\subsubsection{Ação antimicrobiana}

A ação antimicrobiana de vários fito compostos já está bem estabelecida in 
vitro (LIN et al., 2004; TROMBETTA et al., 2005; DUARTE et al., 2005); no entanto, poucas pesquisas descrevem essa ação in vivo, como caracteriza o objetivo do trabalho. Bampidis et al. (2006) oferecem perspectivas interessantes quanto ao uso de fito compostos para o tratamento de infecções bacterianas. Estes autores observaram que a administração de folhas secas de Origanum vulgare (14 g de folhas diluídas em $100 \mathrm{ml}$ de água) ou de sulfato de neomicina (10 mg/kg de peso corporal), ambos via oral, para bezerros acometidos por diarréia neonatal causada por Escherichia coli, levava a efeitos similares: o número de dias com diarréia, severidade de diarréia e taxas de mortalidade foram similares em ambos grupos. Zhang et al. (2005) também observaram diminuição na contagem de Escherichi coli e Clostridium perfringens em amostras de fezes de frangos recebendo uma mistura de óleos essenciais na dieta.

Os métodos mais utilizados para se verificar a ação antimicrobiana dos fito compostos, in vitro, são o de difusão em ágar e o de diluição em caldo de cultura. No método de diluição, é utilizado um disco de papel Whatman e o potencial antimicrobiano do composto é mensurado pelo tamanho da zona de inibição de crescimento do microorganismo. Pelo método de diluição, o resultado geralmente é expresso como concentração mínima inibitória (CMI) do composto capaz de inibir o crescimento de um determinado microorganismo, ou então, como a concentração mínima bactericida (CMB), a menor concentração de uma substância capaz de tornar impossível a sobrevivência de qualquer célula bacteriana (MORENO et al., 2006).

Outros autores avaliaram também o efeito de produtos à base de ervas naturais sobre a modulação da microbiota entérica de suínos e da produção de metabólitos por essas bactérias. Namkung et al. (2004) encontraram evidências de que extratos herbáceos alteram a microbiota de leitões desmamados uma maneira diferenciada que os antibióticos. Enquanto que nos animais recebendo antibiótico (110 ppm de lincomicina) tanto a contagem nas fezes de lactobacilos (microorganismos com ação benéfica no trato entérico) quanto de coliformes fecais (bactérias com potencial patogênico) foi menor, naqueles recebendo extratos herbáceos, somente a contagem de coliformes foi menor, indicando que esses extratos selecionaram microorganismos benéficos, enquanto que os antibióticos agem sobre ambos os tipos de microorganismos. Si et al. (2006) avaliaram a ação de 9 compostos fitoterápicos (m-anisaldeído, geraniol, (DL)-mandelonitrilo, óleo de 
cravo, óleo de canela, carvacrol, eugenol, timol, e 2-tert-butil-4-methilfenol) sobre bactéria patogênicas (Salmonella typhimurium DT104, Escherichia coli O157:H7 e E. coli K88) e benéficas (Lactobacilos e bifidobactérias), concluindo que a ação era maior sobre as patogênicas.

Além de causarem a seleção de bactérias menos nocivas no trato entérico, extratos herbáceos podem modular a produção de substâncias potencialmente tóxicas ao hospedeiro por essas bactérias, o que pode ter impacto tanto na saúde do hospedeiro (USHIDA et al., 2002), quanto na diminuição da poluição ambiental (VARREL; MILLER, 2004). Ushida et al. (2002) verificaram que a adição de extratos de Mentha piperitta, Perilla frutenscens e Ajuga decumbens levou à queda na produção dos seguintes compostos voláteis de enxofre no ceco de suínos: sulfito de hidrogênio, metanetiol e amônia. Não foram observados, no entanto, queda na quantidade de ácidos graxos de cadeia curta. A fração dos extratos a que foi atribuída essa ação foi a n-butanol, que causou alterações no metabolismo bacteriano, já que não foi observado diminuição na quantidade de bactérias produtoras de compostos voláteis de enxofre. Assim, a atividade antimicrobiana dos produtos à base de ervas naturais pode promover uma maior saúde entérica por eliminar bactérias potencialmente patogências e preservar as bactérias benéficas, bem como pela diminuição de metabólitos potencialmente tóxicos produzidos por esses microorganismos.

Em outros estudos, no entanto, não fora observado modulação da microbiota entérica. Fukayama et al. (2005) observaram que a adição de extrato de orégano na ração de frangos de corte ocasionou diminuição tanto de bactérias gram negativas quanto gram positivas. Outros trabalhos também não conseguiram demonstrar qualquer alteração na microbiota de animais suplementados com fito compostos em relação aos do grupo controle (PEDROSO et al., 2005; UTIYAMA, 2005).

Os mecanismos de ação dos diferentes princípios ativos das plantas que compõem o fito composto testado, bem como o espectro de ação dos mesmos será detalhado mais adiante, quando será abordado especificamente sobre essas plantas.

Cowan (1999) verificou que os compostos fenólicos e polifenóis são mais tóxicos quanto maior o número de hidroxilas presentes em suas moléculas. Nesse trabalho são citados autores que descobriram que quanto maior o grau de oxidação dessas moléculas, maior o poder inibitório sobre os microorganismos. Os 
mecanismos responsáveis por sua toxicidade incluem interação desses compostos com proteínas microbianas e inibição enzimática.

Os flavonóides, flavonas e flavonols por sua vez são capazes de se complexar com proteínas microbiana e à parede celular bacteriana, exercendo assim seu efeito antimicrobiano (COWAN, 1999), e, segundo Pengelly (2004), essa capacidade de se aderir e inibir proteínas se dá pela presença de inúmeros grupos aromáticos na estrutura dessa molécula.

Os terpenos, por sua vez, pelo seu caráter lipofílico tendem a se compartimentalizar de uma fase aquosa nas estruturas internas da membrana, e isso pode levar à expansão da membrana, aumento de sua fluidez e permeabilidade, alterações nas proteínas de membrana, inibição da atividade respiratória e alteração nos processos de transporte de íons (COWAN, 1999). Trombetta et al. (2005) descrevem com maior detalhamento mecanismos específicos de toxicidade dos monoterpenos em bactérias. Os efeitos destes podem ser ocasionados pela sua penetração na fração lipídica da membrana plasmática das células dos microorganismos. Essa penetração pode ocasionar em alterações na permeabilidade e vazamento de material intracelular, bem como interações com componentes intracelulares críticos para atividade antibacteriana. Ainda, segundo os autores, a interação dos monoterpenos com as membranas bacterianas depende também da composição lipídica e carga elétrica destas.

Ultee et al. (1999), através de culturas de Bacillus cereus, elucidaram como um terpeno, o carvacrol, exerce ação bactericida. Sendo um composto com propriedades hidrofóbicas, interage com a membrana citoplasmática da célula bacteriana, alterando sua permeabilidade aos cátions $\left(\mathrm{H}^{+}\right.$e $\left.\mathrm{K}^{+}\right)$e alterando o gradiente de íons. Isto leva a alterações no potencial de membrana, dissipação da força motriz gerada anteriormente por esse gradiente de prótons, essencial para a formação de ATP intracelular. Com isso, há diminuição da quantidade intracelular de ATP por inibição da síntese deste composto, de modo que a célula bacteriana não é capaz de obter energia para a realização de suas atividades vitais, o que acarretará na sua morte. Outras são as conseqüências da dissipação da força motriz do gradiente de prótons que contribuem para morte da célula bacteriana: inibição da atividade de certas enzimas em virtude da perda de íons essenciais; perda do turgor celular, influência sobre a síntese de DNA, perda da integridade de membrana em virtude de desbalanços das interações hidrofóbicas entre lipídeos e proteínas. 
Outros autores observaram que óleos essenciais levavam à diminuição da concentração intracelular de ATP por vazamento através da membrana citoplasmática (HELANDER et al., 1998; OUSSALAH et al., 2006).

Di Pasqua et al. (2006) observaram que soluções de metanol de carvacrol, limoneno, cinamaldeído e eugenol ocasionaram alterações na permeabilidade e fluidez da membrana citoplasmática de Escherichia coli O157:H7 e Salmonella typhimurium através de outro mecanismo, a alteração na composição de ácidos graxos insaturados de cadeia longa e aumento na quantidade de ácidos graxos insaturados.

Geralmente, bactérias gram positivas são mais susceptíveis à ação dos óleos essenciais que as gram negativas, pois estas apresentam uma superfície hidrofílica na membrana externa rica em lipopolissacarídeos, formando uma barreira contra macromoléculas hidrofóbicas presentes nos óleos essenciais (OETTING, 2005).

\subsubsection{Ação antioxidante}

Além da ação antimicrobiana, outra importante propriedade dos fito compostos é a antioxidante. Essa ação é importante quando se pesquisa a utilização de fito compostos como promotores de crescimento por duas razões: primeiramente, porque adicionados a ração, podem diminuir a necessidade da inclusão de compostos antioxidantes tradicionalmente usados, como por exemplo o butilhidróxitolueno (BHT), diminuindo assim custos. Leal et al. (2003) encontrou evidências de que o rosmanol, substância presente no alecrim ( $R$. Officinalis), possui propriedades antioxidantes mais efetivas que o BHT e o a-tocoferol. Outro motivo que torna a ação antioxidante de fito compostos interessantes para seu uso na alimentação de animais de produção é a possibilidade de eles melhorarem a qualidade da carne (BOTSOGLOU et al., 2002) e dos ovos (BOTSOGLOU et al., 2005) dos animais alimentados com esses aditivos, protegendo as gorduras da deterioração oxidativa. Essa ação é importante na qualidade da carne de suínos e aves, que são alimentados com óleos de origem vegetal, responsáveis por aumentar a concentração de ácidos graxos poliinsaturados (PUFA) na carcaça, que são muito mais susceptíveis aos processos oxidativos (WENK, 2003). 
Botsoglou et al. (2002) verificaram resposta dose-dependente da inclusão de óleos essenciais na ração de frangos de corte sobre a estabilidade oxidativa na gordura abdominal, do peito e da coxa na carne desses animais. Nesse trabalho, quando houve adição de concentrações mais altas de óleos essenciais de orégano (O. vulgare) na ração, houve maior resistência à oxidação induzida por ferro na carne destas aves, mensurada através do aumento na concentração de malondialdeído. Botsoglou et al. (2004) também constataram melhora na qualidade oxidativa da gordura na carne de coelhos, decorrente da alimentação dos animais com óleos essenciais de orégano.

Há evidências de que a atividade antioxidante dos fito compostos esteja ligada principalmente à quantidade de polifenóis neles presente. Moreno et al. (2006) verificaram a atividade antioxidante de extratos de alecrim (Rosmarinus officinalis) obtidos de diversas formas. Os ensaios foram realizados in vitro, através da técnica espectofotométrica do DPPH (2,2 - difenil -1- picrilidrazila), e os componentes dessa planta responsáveis pela atividade antioxidante foram os polifenóis ácido rosmarínico, rosmanol e o ácido cafeíco. Segundo Pohliti et al. (2004) a atividade antioxidante/redutora dos compostos fenólicos é consistente com o papel de doador de hidrogênio que assumem. Há evidências de que a atividade antioxidante de do alecrim esteja associado principalmente à quantidade de ácido rosmarínico presente no extrato (AL-SEREITI et al., 1999).

Outra planta que apresenta grande atividade antioxidante é a hortelã (Mentha piperita) (SAMARTH et al., 2006). Mímica-Dukïc et al. (2003) demonstraram que os principais componentes da planta responsáveis por essa atividade eram os monoterpenos mentona e isomentona.

\subsubsection{Ação colerética, hepatoprotetora e detoxificadora}

As ervas medicinais vêm há séculos sendo usadas, empiricamente, pela medicina tradicional como agente hepatoprotetor (AL-SEREITI et al., 1999) e colerético (FOURNIER et al., 1948), em especial o alecrim (Rosmarinus officinalis), planta presente no fito composto avaliado. De fato, desde a década de 80 , estudos vêm mostrando a eficácia desta planta como agente hepatoprotetor, detoxificador e 
colerético (HOEFLER et al., 1987).

Substâncias presentes em extratos de Rosmarinus officinalis (ácidos oleanóico, caféico, rosmarínico, carnosóico e clorogênico, além do carnosol, rosmanol e diterpenos), devido à suas propriedades antioxidante, têm a capacidade de bloquear a oxidação da membrana plasmática dos hepatócitos, prevenindo a sua necrose (HOEFLER et al., 1987). Estes autores demonstraram a ação hepatoprotetora de extratos aquosos de brotos e da planta inteira de $R$. officinalis. Neste estudo, os autores administraram tetracloreto de carbono $\left(\mathrm{CCL}_{4}\right)$ a ratos, substância que produz metabólito tóxico que causa peroxidação da membrana dos hepatócitos e necrose hepática. Quando administrados antes do $\mathrm{CCL}_{4}$, esses extratos diminuíam, significativamente, a liberação na corrente sangüínea de uma enzima que indica lesão hepática (glutamino pirúvico transaminase) pelo fígado, em relação ao grupo que não recebeu os extratos. Portanto, esses extratos exerceram ação hepatoprotetora, uma vez que a administração deles após $\mathrm{CCL}_{4}$, não diminuía a liberação de glutamino pirúvico transaminase. Al-Sereiti et al. (1999) também demonstraram que a administração de extratos aquosos de brotos jovens de $R$. officinalis, em hepatócitos de ratos com lesão induzida por hidroperóxido, diminuiu significativamente a liberação na circulação sangüínea de enzimas que indicam lesão hepática (lacticodesidrogenase e aspartato aminotransferase). Essa atividade hepatoprotetora das plantas medicinais pode ter contribuído para os achados de Guo et al. (2004). Estes autores constataram que frangos recebendo um composto de 14 ervas chinesas secas e trituradas apresentaram escore de coloração hepática mais uniforme que aves não suplementadas ou recebendo 20 ppm de virginamicina.

Mais recentemente, vem sendo demonstrado que além de possuir ação hepatoprotetora, $R$. officinallis possui também ação detoxificadora, aumentando a produção das enzimas metabolizadoras de xenobióticos pelo fígado. Debersac et al. (2001) demosntraram que extratos (extrato aquoso, extrato solúvel em diclorometano e óleos essenciais) da planta agiram tanto sobre enzimas de fase I (enzimas do complexo citocromo P450, ou CYP), quanto enzimas de fase II (detoxificadoras) dos hepatócitos, após administração via oral para ratos. Extratos aquosos e óleos essenciais aumentaram as seguintes atividade das enzimas do CYP: etoxiresorrufin O-deetilase, metoxiresorrufin O-demetilase e pentoxiresorrufin O-dealquilase; os óleos essenciais também aumentaram a imunodetecção da isoforma CYP2B1/2 da enzima no microssoma dos animais tratados. A atividade das 
enzimas de fase II (glutationa S-transferase, ou GST; NAD $(\mathrm{P}) \mathrm{H}$ :quinona redutase, ou QR; e UDP-glicoronosiltransferase, ou UGT) também foi aumentada por extratos de R. officinalis. Assim, óleos essenciais induziram as CYP; extratos solúveis em diclorometano agiram com maior intensidade sobre GST, UGT e QR; e extratos aquosos agiram tanto sobre as CYP quanto nas enzimas de fase II. Outra conclusão que os autores extraíram deste trabalho é que as substâncias presentes nos extratos de plantas medicinais têm sua ação potencializada quando administradas juntas do que em separado, possivelmente pelo fato de algumas substâncias presentes nos extratos aumentarem a estabilidade de outras, tornando o ambiente químico do extrato mais favorável à ação dos princípios ativos.

Essa maior produção de enzimas de detoxificação hepáticas pode ter contribuído para aumento do peso hepático encontrado em vários estudos, após a administração de extratos herbáceos. Denli et al. (2004) constataram que codornas recebendo 60 ppm de óleos essenciais de tomilho ou não recebendo aditivo algum à dieta apresentaram maior peso hepático que aves consumindo 10 ppm de avilamicina. Oetting (2005) observaram que, numericamente, o peso hepático de leitões recebendo extratos herbáceos foi maior que de leitões não suplementados.

Hoefler et al. (1987) demonstraram também que extratos solúveis em solventes orgânicos de broto de alecrim também aumentam o fluxo de bile, sendo a resposta dose-dependente. Após 150 minutos decorridos da aplicação, tanto a solução com 500, 1000 e 2000 mg/kg aumentou o fluxo biliar, sendo que a ação de uma substância usada como controle positivo, o deidrocolato de sódio, possuiu ação intermediária entre a solução de 500 e 1000 mg/kg.

\subsubsection{Ação sobre a morfometria do trato gastrointestinal}

Além da ação antimicrobiana que as ervas medicinais podem exercer, selecionando alguns microorganismos benéficos no trato gastrointestinal, podem ser citados também como causa de melhoras nos índices de desempenho destes compostos adicionados à ração: aumento na digestibilidade e absorção de nutrientes e modificações morfo-histológicas no trato gastrointestinal (BUGRALLI, 2003). Esses fatores podem explicar a melhor digestibilidade da matéria seca em relação a animais controle observados por Oetting (2005). 
Outro efeito benéfico dos fito compostos é sobre a histologia do epitélio intestinal. No período pós desmame, há normalmente atrofia dos vilos devido a aumento nas taxas de descamação ocasionadas pela ação de bactérias patogênicas e por mudanças na dieta. Como resposta, há aumento na proliferação celular da cripta de Lieberkühn, que garante a renovação dos enterócitos descamados nos vilos, levando ao aumento na profundidade dessas criptas. A maior descamação das células dos vilos pode ocasionar diminuição na digestibilidade da ração, já que ocorre (1) menor produção de enzimas digestivas nas bordas em escova e (2) diminuição na área de absorção de nutrientes (ITO et al., 2004). Ainda, há maior atividade secretória, pois os enterócitos, quando presentes nas vilosidades, possuem atividade absortiva, e quando presentes nas criptas, atividade secretória de muco (BUDDLE; BOLTON, 1992). Essa maior atividade secretora, aliada à presença de alimentos mal digeridos no intestino, podem ainda agravar o quadro de diarréia desses leitões (VENTE-SPREEUWENBERG et al., 2004). Com relação à histologia do epitélio intestinal, Utiyama (2004) observou que leitões suplementados com extrato vegetal apresentavam maior altura de vilosidades e menor profundidade de cripta. Além disso, houve menor quantidade de células caliciformes no epitélio do intestino dos animais suplementados (embora não significativa estatisticamente), estruturas essas produtoras de muco que aumentam a atividade em resposta a estímulos agressivos sobre o epitélio. Todas essas alterações pressupõem uma diminuição no grau de infecção sobre o epitélio intestinal em leitões que receberam o fito composto.

Outra conseqüência da diminuição da quantidade de bactérias patogênicas no trato entérico ocasionada pelos fito compostos sobre a morfometria do sistema gastrointestinal é a diminuição do peso relativo do intestino delgado. Segundo Bampidis et al., 2005a presença de bactérias patogênicas no intestino leva ao aumento no peso do órgão, ocasionado por espessamento da parede devido a inflamações crônicas. A adição de fito compostos levou a diminuição do peso relativo do órgão (UTIYAMA, 2004; BAMPIDIS et al., 2005).

\subsubsection{Ação sobre a atividade enzimática}

A melhora na digestibilidade ocasionada pelos fito compostos pode também 
ser reflexo de uma melhor atividade secretora de enzimas digestivas ocasionadas por esses compostos. Segundo Oetting (2005), os extratos vegetais podem estimular aumento na secreção de saliva, de enzimas pancreáticas e de suco gástrico, o que leva ao aumento da digestibilidade do alimento, por um lado, e aumento da proteção contra microorganismos patogênicos por outro, já que uma maior secreção do suco gástrico vai diminuir o $\mathrm{pH}$ no estomago e tornar o ambiente estomacal mais inóspito aos microorganismos patogênicos.

Utiyama (2004) relatou aumento no peso do pâncreas de leitões que receberam fito composto na dieta, comparativamente a animais que receberam aditivos e que não receberam nenhuma suplementação, o que pode ter ocasionado em aumento da atividade do pâncreas exócrino. Outra pesquisa demonstrou que extratos de Rosmarinus officinalis podem exercer ação colerética, o que pode melhorar a digestibilidade de lipídios (HOEFLER et al., 1987). Segundo Pengelly (2004), alguns fito compostos ainda promoveriam aumento no apetite, uma vez que os óleos essenciais contêm diterpenos, que são substâncias de sabor amargo e que assim estimulariam receptores gustativos na língua dos animais, promovendo aumento na salivação e secreções de suco gástrico e hormônios relacionados á ingestão de alimentos.

A maior atividade secretora de enzimas digestivas ocasionadas pelos extratos vegetais vai assumir grande importância na fase inicial de creche, sobretudo nas primeiras semanas, pois nessa fase o leitão sofre uma queda transitória na produção de enzimas digestivas (MARION et al., 2003), o que é acompanhado por uma concomitante diminuição da altura de vilosidades do epitélio intestinal (NABUURS et al., 1993).

\subsubsection{Ação sobre o sistema imune}

Citocinas pró inflamatórias, entre elas as interleucinas $1 \beta$ e 6 (IL-1 $1 \beta$, IL-6), e o fator de necrose tumoral (TNF- $\alpha$ ) estão incriminadas na diminuição do crescimento, e conseqüentemente, do desempenho dos animais. Segundo Broussard et al. (2001), as citocinas pró-inflamatórias induzem a uma resistência aos receptores hepáticos do hormônio de crescimento $(\mathrm{GH})$, levando a redução do fator de 
crescimento insulina semelhante (IGF-I), que promove a síntese protéica de mioblastos. Podem ainda levar à depressão do consumo alimentar (FINCK; JOHNSON, 2000; CALICH; VAZ, 2001). Escobar et al. (2004) verificaram o impacto que a infecção pulmonar viral (vírus da síndrome reprodutiva e respiratória suína, PRRSV) ou bacteriana (Mycoplasma hyopneumoniae) exercem sobre a produção de citocinas e a deposição muscular de proteína em suínos com idade de 6 semanas, e concluiram que a magnitude do aumento das citocinas inflamatórias causado por infecções pulmonares crônicas está associada a diminuição do crescimento e deposição de proteína muscular, em parte através do aumento na síntese muscular de miostatina (MSTN), um regulador negativo da síntese muscular. Neste estudo, PRRSV levou a aumento nas concentrações plasmáticas de IL-1, IL-6 e na quantidade de RNAm que codifica a miostatina (MSTN) na musculatura esquelética, e diminuiu o consumo alimentar, ganho diário de peso e a acreção de proteína e gordura. Além disso, o peso dos músculos bíceps femoral e tríceps estava negativamente correlacionado com as concentrações séricas de IL-1, IL-6 e com RNAm de MSTN na musculatura.

Portanto, um dos fatores responsáveis por diminuição no desempenho de animais criados intensivamente e confinados é a estimulação crônica da produção de citocinas inflamatórias, devido principalmente aos diferentes e até muitas das vezes altos níveis de contaminação ambiental. O nível de contaminação ambiental é especialmente alto em granjas comerciais, que apresentam um fluxo contínuo de animais sem que haja o devido vazio sanitário das instalações para diminuir a presença de patógenos, enquanto que em granjas experimentais pode não ser tão alto, já que o fluxo de animais não é tão grande.

Além das citocinas inflamatórias, outro marcador biológico que pode ajudar na estimação do grau de estimulação do sistema imune e do impacto disto sobre a perormance animal são as proteínas de fase aguda, dentre elas a haptoglobina e a glicoproteína a-1-ácida (AGP). Essas substâncias são produzidas pelo fígado em resposta às citocinas e estão associadas à condições inflamatórias e infecciosas nos animais de produção, possivelmente tendo a função de reestabelecer a homeostase biológica (HOLCK et al., 1998).

Tem sido demonstrado que a ação terapêutica de várias ervas medicinais decorre de propriedades imunomoduladoras de componentes destas plantas sobre as citocinas (SPELMAN et al., 2006). Algumas plantas utilizadas no tratamento 
contra o reumatismo em humanos e foi demonstrado que a a atividae destas plantas decorre da diminuição da expressão de genes relacionados à produção de interleucinas. Foi demonstrado, por exemplo, que extratos de Triptrerygium wilfordii são capazes de inibir a produção de citocinas de fagócitos mononucleares, inibindo a regulação de alguns genes pró-inflamatórios, tais quais TNF- $\alpha$, ciclooxigenase-2, interféron- $\gamma$, prostraglandinas e óxido nítrico sintetase (SETTY; SIGAL, 2005). Possivelmente, esta propriedade está relacionada com melhora nos índices de crescimento de animais de produção mantido sob condições intensivas de criação, já que estes tendem a apresentar uma maior estimulação do sistema imune e da produção de citocinas. A adição de extratos de Quillaja saponaria na dieta de leitões desmamados causou depressão da função fagocítica no sangue destes animais (TURNER et al., 2002a). Al-Sereiti et al. (1999), em uma revisão sobre a ação das substâncias presentes na planta Rosmarinus officinalis, cita vários estudos em que o ácido rosmarínico exerce ação imunomoduladora, tais como inibição de mediadores inflamatórios em leucócitos polimorfonucleares (ácido 5-hdroxil-6,8,11,14ecosatetraenóico e leucotrieno $B_{4}$ ), estímulo da produção de prostaglandina $E_{2} e$ inibição de reações do sistema complemento. Maass et al. (2005) observaram aumento na resposta vacinal de erisipela no soro de suínos que receberam aditivos fitogênicos na alimentação, evidenciado através do aumento no título de anticorpos anti-erisipela. Outros autores, no entanto, não observaram influência de fitoterápicos sobre os níveis séricos de citocinas (NAMKUNG et al., 2004), o que pode ter sido ocasionado pelo baixo nível de contaminação no ambiente em que os animais estavam alocados. Turner et al. (2002a,b) também não observaram influência de extratos herbáceos sobre os níveis de proteínas de fase aguda do fígado (AGP e haptoglobulina), em leitões inoculados experimentalmente com Salmonella typhimurium.

\subsubsection{Ação promotora de crescimento das plantas medicinais}

Anteriormente, foi comentado sobre os mecanismos de ação antimicrobianos dos fito compostos, mostrando as interações moleculares de cada um com as células dos microorganismos e espectro de ação antimicrobiana de cada uma delas. 
Muitas delas apresentam ação mais acentuada até mesmo que os próprios antibióticos (MIMICA-DUKÏC et al., 2003). Baseado nessa ação que foi proposto seu uso na ração como alternativa aos antibióticos usados com a função de promotores de crescimento. No entanto, o aumento na secreção enzimática digestiva e bile, a atividade imunomodulatória, os efeitos sobre a morfologia do epitélio do trato gastrointestinal torna o uso destas substâncias em animais de produção atrativa, bem como a possibilidade de melhora na qualidade de carcaça através da ação antioxidante.

Vários experimentos que avaliaram o efeito de ervas medicinais sobre as variáveis de desempenho apresentaram resultados conflitantes, chegando mesmo a conclusão de que em alguns deles que não havia diferença entre a suplementação ou não com fito compostos (GIANNENAS et al., 2003; BOTSOUGLOU et al., 2002; FUKAYAMA et al., 2005). No entanto, deve ser destacado que a maioria dos estudos não foram realizados em condições de campo, de modo que o desafio sanitário era menor. Sendo assim, os promotores de crescimento não exercem sua função (BOTSOUGLOU et al., 2002; SPINOSA et al., 2002). Alguns autores, no entanto, atribuíram algumas possíveis propriedades anti-nutricionais a alguns compostos presentes nas ervas medicinais. Segundo Lule e Xia (2005), alguns compostos podem se complexar com: proteínas presentes nos alimentos, tornando-as indisponíveis para as enzimas digestivas; com as próprias enzimas digestivas (lípases, amilase e tripsina); com alguns carboidratos e vitaminas presentes na dieta e com o ferro. Ainda, segundo esses autores, esses compostos podem levar a diminuição no consumo alimentar.

Oetting (2005) avaliou, em leitões na fase de creche, um fito composto a base de extratos vegetais (cravo, eugenol, orégano, carvacrol e tomilho), em relação a agentes antimicrobiano e a animais que não receberam aditivo na ração. Houve melhor conversão alimentar para os tratamentos com antimicrobianos e com níveis maiores de inclusão do fito composto (2100 ppm), apesar dos resultados não serem estatisticamente significativos. As outras variáveis de desempenho não foram afetadas. Resultado semelhante obteve Utiyama (2004), avaliando também fito compostos na ração de leitões na fase de creche (extratos de alho, cravo, canela, pimenta, tomilho, cimaldeído e eugenol): dos 15 aos 35 dias de creche, a conversão alimentar fora $6,9 \%$ inferior em relação aos animais controle, apesar dessa diferença não ser estatisticamente significativa. O consumo diário daqueles, no entanto, fora 
menor no período.

Trabalhos demonstraram melhora nos índices de desempenho (BAMPIDIS et al., 2005), incluindo folhas secas de orégano na ração de perus, constatando-se melhora da eficiência de conversão alimentar. Pedroso et al. (2005) também observaram efeito positivo na conversão alimentar, ganho diário de peso e escore de diarréia em leitões que receberam fito composto em relação ao grupo controle.

Além de melhora nos índices de desempenho zootécnico, Allan e Bilkei (2003) aponta efeitos aparentes nos índices reprodutivos de porcas e marrãs propiciados pela adição à ração de fito composto a base de folhas e flores de orégano (O. vulgare) ressecadas e enriquecido com $500 \mathrm{~g} / \mathrm{kg}$ de óleos essenciais da planta, dias antes dos animais parirem. Foram observados diminuição na taxa anual de mortalidade de fêmeas e no descarte de fêmeas, e aumento na taxa de parição, no número de nascidos vivos por leitegada, e diminuição na taxa de natimortos. Houve também aumento no consumo alimentar de porcas suplementadas em relação as do grupo controle. Esses resultados foram atribuídos ao efeito antibacteriano do orégano, diminuindo principalmente o número de fêmeas afetadas por doença urogenital e pela síndrome mastite-metrite-agalaxia.

\subsubsection{Plantas utilizadas no composto: princípios ativos e espectro de ação antimicrobiana}

O fito composto testado possui em sua composição folhas secas e moídas de 4 espécies de plantas: hortelã (Mentha piperita), alecrim (Rosmarinus officinallis), alecrim pimenta (Lippia sidoides) e arnica mineira (Lychnophora pinaster). A ação deste mesmo fito composto já fora testada anteriormente por Martins et al. (2005) em suínos de crescimento e terminação. As características avaliadas foram peso aos 77, 104 e 147 dias de idade; ganho médio de peso diário (GDP) e conversão alimentar (CA). Verificou-se que, na fase de crescimento, tanto o GDP quanto a CA alimentar foram melhores nos animais do grupo que recebeu o fito composto na ração e no que recebeu como aditivo antibiótico do grupo das quinoxalinas (não diferindo entre eles), em relação aos animais que não receberam aditivo algum. 


\subsubsection{Alecrim (Rosmarinus officinalis)}

O alecrim (Laminacea) é uma planta originária dos países mediterrâneos e amplamente distribuída pelo mundo todo (ABREU-MATTOS, 2000). Suas propriedades terapêuticas já são conhecidas a muito tempo pela humanidade, sendo usadas como agente colerético e diurético (HOEFLER et al., 1987), antiespasmódico, antisséptico, antidepressivo, antireumático, carminativo, digestivo, diurético, hipertensivo (KABOUCHE et al., 2005). Guarrera (2005) cita o uso dessa planta contra resfriados e como agente espectorante há séculos na Itália central.

Os principais compostos com ação antimicrobiana presentes nessa planta são o ácido rosmarínico (e seu precursor, o ácido cafeíco), o carnosol e os diterpenos fenólicos ácido carnósico (MORENO et al., 2006). Óleos essenciais dessa planta apresentam predominantemente 1,8 cineole e cânfora (DEBERSAC et al., 2001; KABOUCHE et al., 2005). Flavonóides também estão presentes nos extratos dessa planta (OLUWATUYI et al., 2004).

A ação antimicrobiana dos extratos de alecrim está correlacionada a seus componentes pertencentes ao grupo dos polifenóis, já que extratos solúveis em água, apresentando somente ácido rosmarínico e não os outros princípios ativos, apresentaram baixa atividade em relação aos extratos solúveis em acetona e metanol. Este último, com a seguinte composição: 30\% de ácido carnósico, 16\% de carnosol e $5 \%$ de ácido rosmarínico foi o mais efetivo contra bactérias gram negativas, incluindo Escherichia coli (MIC entre 2 e $60 \mu \mathrm{g} / \mathrm{ml}$ ), gram positivas (MIC entre 2 e $15 \mu \mathrm{g} / \mathrm{ml}$ ) e fungos (MIC de $4 \mu \mathrm{g} / \mathrm{ml}$ ) (MORENO et al., 2006).

Kabouche et al. (2005) verificaram a atividade de óleos essenciais da planta contra algumas linhagens de bactérias, apresentando atividade efetiva somente contra Pseudomonas aeruginosa e Klebsiella pneumoniae, não inibindo o crescimento de Escherichia coli, Bacillus subtilis, Enterobacter aerogenes e Staphylococcus aureus. Os autores atribuem esse resultado, em desacordo com várias outras pesquisas (NASCIMENTO et al., 2000), ao fato de haver na amostra de planta utilizada para extração dos óleos essenciais alta porcentagem de 2-etil-4,5dimetilfenol.

Além de exercer atividade antimicrobiana por si só, algumas substâncias presentes no alecrim podem apresentar ação sinérgica com antibióticos. Oluwatuyi 
et al. (2004) adicionou carnosol e ácido carnósico em meios de cultura semeados com Staphylococcus aureus que adquiriram resistência a antibióticos; com isso, houve potencialização da atividade antimicrobiana da eritromicina respectivamente de 16 e 32 vezes para os dois fito químicos. Esse efeito, segundo os autores, se dá pela inibição de um dos mecanismos de defesa do microorganismo aos antibióticos, a bombas de efluxo das moléculas do antibiótico.

Outras ações atribuídas aos extratos de alecrim são os de hepatoproteção e aumento da secreção de bile (HOEFLER et al., 1987) e indução de várias enzimas hepáticas de detoxificação e do citocromo P450 (DEBERSAC et al., 2001), o que leva a crer que sejam potenciais agentes que dificultem a carcinogênese.

\subsubsection{Hortelã (Mentha piperita)}

Assim como o alecrim, a hortelã é uma planta cultivada no mundo todo devido a características como aroma, sabor e propriedades médicas e farmacêuticas. São adicionadas aos alimentos, utilizadas na forma de chás e em confeitarias (ISCAN et al., 2002).

As principais substâncias responsáveis pelos efeitos biológicos da hortelã estão presentes na fração óleo essencial da planta. São eles os seguintes terpenos: mentol, mentona e isomentona (ISCAN et al., 2002). Ainda, há outra substância presente nessa planta, o mentofurano, que também lhe confere efeitos terapêuticos (ABREU-MATTOS, 2000). Mimica-Dukïc et al. (2003), extraindo óleo essencial através de hidrodestilação, obteve $3,73 \%$ dessa fração; nesta, mentil correspondeu a $39,63 \%$, mentil acetato a $10,44 \%$ e mentona a $8,93 \%$. Foi demonstrado que a hortelã possui ação antibacteriana (ISCAN et al., 2002; MIMICA-DUKÏC et al., 2003), anticarcinogênica (SAMARTH et al., 2006), antifúngica (ALAN; BILKEI, 2003; MIMICA-DUKÏC et al., 2003), antinflamatória e espasmolítica (LIS-BALCHIN; HART, 1999). Inoue et al. (2001) reportou também ação de outras frações dessa planta. Nessa pesquisa, foi verificado que extratos da planta possuíam ação antialérgica, através de um modelo de indução experimental de rinite alérgica em ratos: houve diminuição tanto na permeabilidade vascular quanto da liberação de histamina de mastócitos colhidos na cavidade peritonial e inoculados na cavidade nasal. 
A hortelã possui um amplo espectro de ação antibacteriana, conforme demonstrado in vitro: Escherichia coli, Salmonella thyphimurium, Salmonella enteriditis, Shigella sonei, Sarcina lutea, Micrococcus flavus, Staphylococcus aureus, Staphylococcus epirdemitis e Bacillus subtilis (TROMBETTA et al., 2005). De maneira geral, bactérias gram positivas são mais susceptíveis (MIMICA-DUKÏC et al., 2003).

Em contraste a essa amplitude de ação, Iscan et al. (2002) verificou que a planta possuía ação apenas moderada contra bactérias patogênicas, inibindo apenas Listeria monocytogenes efetivamente. Vários fatores podem, no entanto, influenciar negativamente a determinação in vitro da atividade antimicrobiana de óleos essenciais: por apresentarem baixa solubilidade em água e alta viscosidade a distribuição do óleo no meio pode ficar comprometida; longos períodos de incubação também podem resultar em evaporação ou decomposição de alguns componentes presentes nos óleos essenciais durante o período de teste; a condição do meio de cultura; concentração e validade do inócuo utilizado; temperatura e tempo de incubação; tipo de solvente ou agente dispensor utilizado (OETTING, 2005). Alterações na composição dos óleos essenciais devido a fatores relacionados com as plantas utilizadas, tais como localização geográfica, clima e época do ano em que houve a colheita, podem implicar também em alterações em suas atividades (PERRY et al., 1999; LAMBERT et al., 2001; DEL-BAÑO et al., 2004; LETCHAMO et al., 2004).

\subsubsection{Alecrim pimenta (Lippia sidoides)}

É um arbusto que ocorre naturalmente na região nordeste do Brasil. $\mathrm{Na}$ medicina tradicional, partes aéreas dessa planta são usadas como anti-sépticos; esse uso faz sentido, uma vez que óleos essenciais dessa planta contêm predominantemente timol e carvacrol, agentes com ação reconhecida contra fungos e bactérias (COSTA et al., 2001; CARVALHO et al., 2003). Estas duas substâncias estão presentes também em outra planta medicinal, Oreganum vulgare, que vem sendo foco de inúmeras pesquisas atualmente e possui comprovada ação antibacteriana.

Trabalhos realizados por Girão et al. (2003) não identificaram o carvacrol nos 
óleos essenciais dessa planta, somente o timol (este correspondente a 66,67\% da fração óleo essencial). Nessa pesquisa, o efeito de um creme bucal preparado com óleos essenciais da planta foi testado em cães com gengivite. Como resultado, houve diminuição na intensidade das alterações inflamatórias da gengivite, nos graus de placa bacteriana, no cálculo e também no infiltrado inflamatório nos animais que receberam o creme, o que não ocorreu com os animais do grupo controle. Esses resultados foram conseqüência a ação antimicrobiana da planta. Lemos et al. (1990) também verificou excelente ação antimicrobiana dessa planta contra as bactérias Staphylococcus aureus, Bacillus subtilis, Mycobacterium smegmatis e contra os fungos Cryptococcus neoformans, Saccharomyces cerevisiae Aspergillus flavus e Trichophyton mentagrophytes. Neste estudo fora verificada ação moderada contra Escherichia coli e Pseudomonas aeruginosa.

Carvalho et al. (2003) testou a atividade larvicida de óleos essenciais do alecrim pimenta contra Aedes aegypti. Houve morte de $100 \%$ das larvas pelos óleos essenciais; concluiu-se que o timol provocou esse efeito.

Lambert et al. (2001) estudou a MIC de óleos essenciais de orégano ( $O$. vulgare), que assim como o alecrim pimenta, possui como princípios ativos o timol e o carvacrol. Houve maior susceptibilidade do Staphylococcus aureus em relação a esses dois princípios ativos do que Pseudomonas aeruginosa. Contrariamente aos achados de Carvalho et al. (2003), foi observada nessa pesquisa efeito aditivo entre os princípios ativos.

Os mecanismos de ação responsáveis pelo efeito antimicrobiano são: penetração no periplasma das bactérias através das porinas da membrana, aumento da permeabilidade dessa membrana, dissipação do gradiente de $\mathrm{pH}$ e do potencial elétrico. Essas alterações acabam por acusar danos estruturais e funcionais à membrana plasmática (LAMBERT et al., 2001).

Costa et al. (2001) descreve também ação citotóxica em células tumorais humanas de extratos da planta solúveis em etanol, sendo o tectol e a lippidoquinona responsáveis por esse efeito.

\subsubsection{Arnica mineira (Lychnophora pinaster)}

É uma planta típica do cerrado brasileiro. Há poucos dados na literatura sobre 
a ação dos componentes dessa planta, bem como de sua atividade antimicrobiana. Ferreira et al. (2005) identificou alguns de seus princípios ativos, sendo eles o ácido cinâmico, ácido cafeíco, pinobaksin e ácido clorogênico.

\subsection{INOCULAÇÃO EXPERIMENTAL DE PATÓGENOS ENTÉRICOS: MODELO DE BAIXA HIGIENE NA CRECHE}

Já foi discutido anteriormente que os promotores de crescimento só exercem efeito sob condições de desafio (SPINOSA et al., 2002). Uma vez que o presente estudo foi conduzido em uma granja experimental, cujo desafio microbiológico é muito baixo em relação às condições de campo devido ao menor fluxo de animais, optou-se em utilizar o "modelo de baixa higiene na creche", preconizado por Johnson et al. (2005), para uma melhor detecção do efeito do fito composto utilizado como promotor de crescimento. Os autores avaliaram as respostas de leitões após administração via oral de Salomonella entérica sorovar Typhimurium sobre a imunidade local do trato entérico e do sistema IGF local, observando que $S$. typhimurium rapidamente interage com o epitélio intestinal, regulando a atração para o local de IL-8 (mRNa de IL-8 aumentou gradativamente nas placas de Peyer de suínos recebendo inoculação via oral de S. Typhimurium) e quimiocina ligand-20, e seletivamente afetando os receptores toll-like, levando também a alguns sinais sistêmicos de ativação imunológica (febre, inapetência, aumento da secreção plasmática de cortisol). Não foram observados, no entanto, alterações nas concentrações plasmáticas de outras citocinas, tais como TNF- $\alpha$ ou IL-6, cujas concentrações normalmente aumentam em modelos experimentais nos quais é injetado lipopolissacarídeos. Resultados semelhantes foram obtidos por Balaji et al. (2000) e por Fraser et al. (2007), que inocularam por via oral leitões em fase de creche com S. typhimurium (os primeiros realizaram administração única com $3 \times 10^{9}$ u.f.c., enquanto Fraser et al. (2007) realizou administração de $10^{8}$ u.f.c. duas vezes por semana durante 14 dias). Em ambos os estudos não foram detectadas alterações nos níveis plasmáticos de TNF- $\alpha$, Prostaglandina $E_{2}$ e IL-1 $1 \beta$, mas foi observado aumento significativo nos níveis plasmáticos de cortisol de 18 até 60 horas após a inoculação, apesar de ser constatado aumento na temperatura retal 
somente por Balaji et al. (2000). Em sua totalidade, esses resultados trazem forte evidência de que a inoculação via oral com $S$. typhimurium provoca uma resposta imunológica confinada localmente, na mucosa do trato gastrointestinal e nos linfonodos mesentéricos, apesar de sinais sistêmicos de ativação imunológica consistente com a sinalização do perigo estarem também presentes.

Johnson et al. (2005) ainda observaram uma queda aguda no consumo alimentar uma semana após a inoculação, a qual é acompanhada por alteração nos reguladores endócrinos do crescimento. Houve diminuição de IGF-1 no soro, um fator que, dentre outras ações, é um mediador da hipertrofia da musculatura esquelética (BARTON-DAVIS et al., 1998) e está associado à diminuição da proteólise (CHRYSIS; UNDERWOOD, 1999). Apesar disso, parece não haver uma queda correspondente de mRNA que codifica IGF-1 e IGFBP-3 na musculatura esquelética, apesar de haver queda no m-RNA que codifica IGFBP-5 no tecido. Levando em conta todas essas informações, pode se inferir que a inoculação experimental de Salmonella typhmurium pode levar à alteração no desenvolvimento de massa muscular e crescimento dos leitões, repercutindo sobre o desempenho e crescimento dos leitões. Confirmando essa hipótese, Balaji et al. (2000) observaram diminuição tanto do ganho diário de peso até 2 semanas após a inoculação experimental quanto a diminuição no consumo alimentar até $120 \mathrm{~h}$ após a inoculação, resultados conflitantes com Fraser et al. (2007), que não observaram influência da inoculação de Salmonella typhmurium sobre o desempenho dos leitões nem sobre a concentração sérica de IGF-I. 
MATERIAL E MÉTODO 


\section{MATERIAL E MÉTODO}

\subsection{FASE DE CRECHE}

\subsubsection{Animais}

Foram utilizados 124 leitões recém-desmamados, linhagem Topigs $₫$, com 21 dias de idade, provenientes de granja comercial (Fazenda Água Branca, Indaiatuba, SP).

\subsubsection{Local e instalações}

Esta fase foi desenvolvida na unidade de creche do Laboratório de Pesquisa em Suínos (LPS), da Faculdade de Medicina Veterinária e Zootecnia da Universidade de São Paulo (FMVZ-USP), Campus de Pirassununga. Essa unidade conta com gaiolas suspensas com piso aquecido e parcialmente ripado, constituídas de comedouro individual e bebedouro tipo chupeta. $O$ estudo conduziu-se em duas salas isoladas entre si, previamente lavadas, desinfetadas com amônia e glutaraldeído, caiadas e passando por período de vazio sanitário, obedecendo a metodologia experimental imposta para a averiguação proposta. A foto da instalação de creche do LPS, bem como a vista no interior da sala não desafiada são mostrados respectivamente nas figuras 5 e 6. 


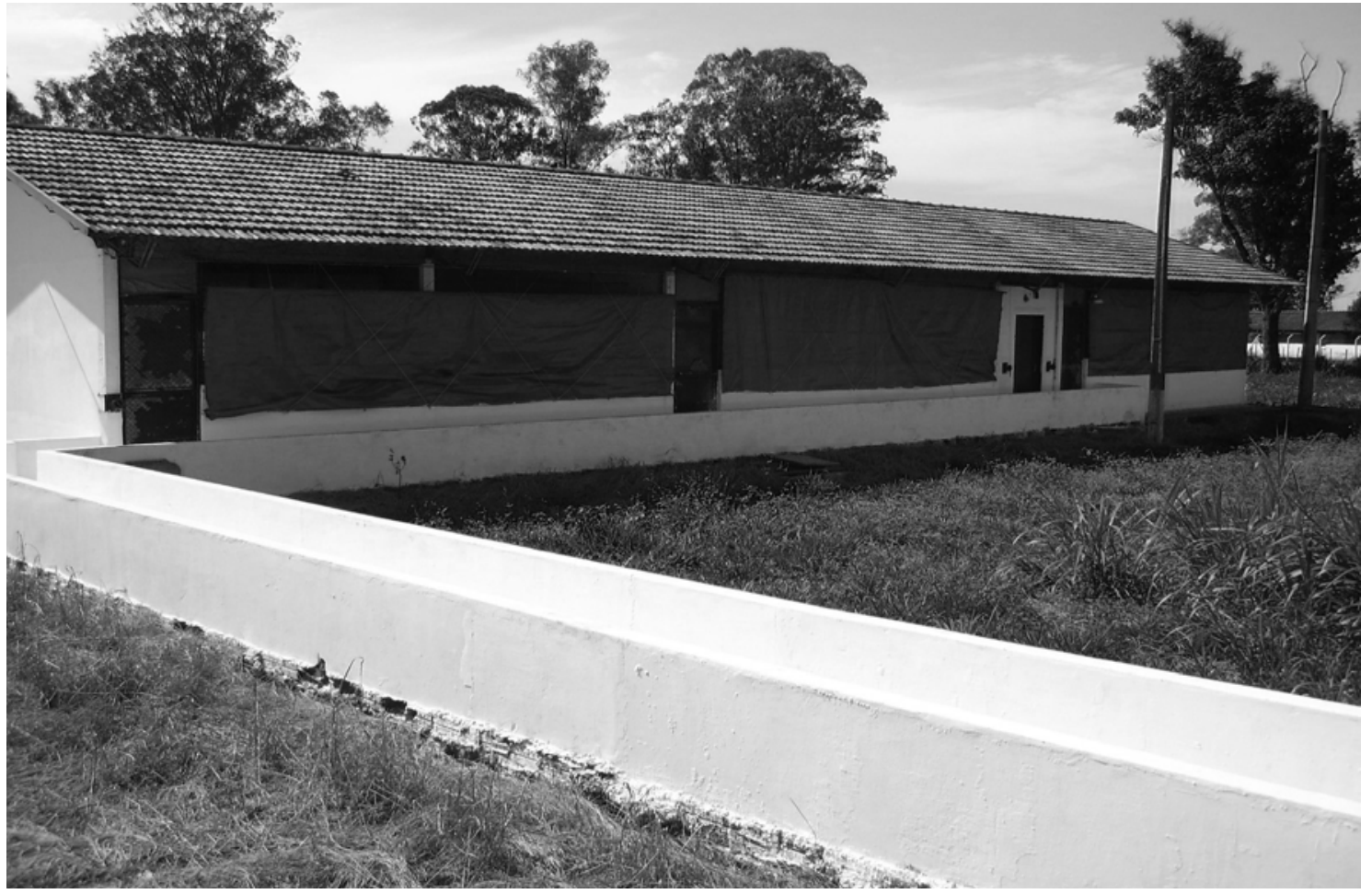

Figura 5 - Instalações de creche do Laboratório de Pesquisa em Suínos (LPS). Foram utilizadas as salas das extremidades esquerda e direita (respectivamente, sala sem desafio e com desafia)

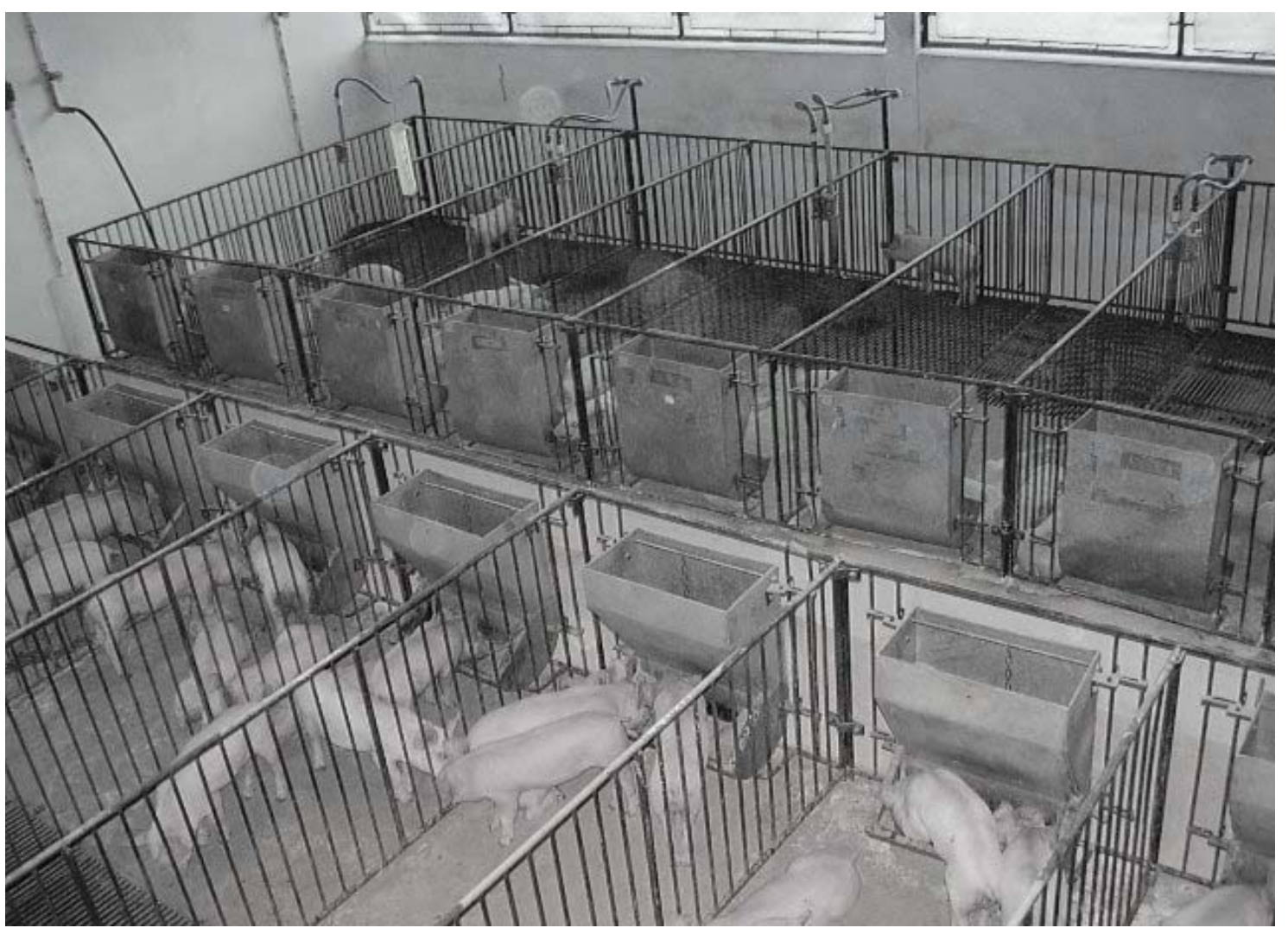

Figura 6 - Leitões alocados na sala sem desafio (SD) 


\subsubsection{Delineamento experimental}

O delineamento foi inteiramente casualisado, com arranjo fatorial de tratamentos $3 \times 2$, sendo um fator a presença do aditivo à ração (antibiótico-ATB, fitocomposto-FITO e ausência dos dois-CTRL) e o outro fator o desafio experimental (com-d ou sem-sd desafio) constituindo nos seis tratamentos: FITOd e FITOsd - emprego do fito composto, respectivamente na sala desafiada e sem desafio; ATBd e ATBsd - emprego do antibiótico, respectivamente na sala desafiada e sem desafio (controle positivo); CTRLd e CTRLsd - ração não suplementada com promotores de crescimento na sala desafiada e na não desafiada (controle negativo). ATB, CTRL e FITO foram distribuídos em cada sala da creche, preenchendo assim, duas salas com 15 unidades experimentais cada (gaiolas suspensas). Nessas salas foram alojados quatro leitões/gaiola, sendo uma delas sem o desafio e outra, completamente isolada da primeira, com o desafio.

\subsubsection{Alimentação e Manejo}

A água e a ração foram fornecidas ad libitum aos leitões. As formulações obedeceram às empregadas comercialmente nas criações, sendo fornecidas pela empresa AC Agroindustrial Ltda (Bauru, SP) havendo somente a suplementação ou não do FITO e ATB (tabela 1). A composição bromatológica das rações é dada na tabela 2. O fito composto era constituído por partes aéreas (folhas, flores e caules) de quatro plantas: Mentha piperita (hortelã), Rosmarinus officinalis (alecrim), Lippia sidoides (alecrim - pimenta) e Lychnophora pinaster (arnica mineira), colhidas no mês de junho de 2007, secas ao sol e trituradas. A taxa de inclusão na ração foi de 2000 ppm (partes por milhão).

As rações foram trocadas com a coincidência das pesagens dos animais, sendo assim denominadas: pré-inicial (dos 21 aos 35 dias de idade, 
suplementadas, no grupo com antibiótico, com 70 ppm de tilosina, 30 ppm de sulfato de colistina, e 2 ppm de ração com óxido de zinco); inicial 1 (dos 36 aos 49 dias de idade, suplementadas, no grupo com antibiótico, com 70 ppm de tilosina, 10 ppm de sulfato de colistina, e 2 ppm de ração de óxido de zinco) e inicial 2 (dos 21 aos 35 dias de idade, suplementadas, no grupo com antibiótico, com 70 ppm de tilosina, 10 ppm de sulfato de colistina, e 2 ppm com óxido de zinco).

Os leitões não receberam vacinação ou qualquer medicamento durante o período experimental. Diariamente, no período da manhã, era realizada a aferição da temperatura das salas, lavagem da parte ripada das baias e era anotada a consistência das fezes. Por toda a instalação foram espalhadas iscas mosquicidas. Na primeira semana do experimento, em razão das baixas temperaturas que acometeram a região, uma lona plástica era posta na parte superior das baias à 18h, para diminuir a perda de calor durante o período noturno, sendo retiradas entre 8 e 9 h, na dependência da temperatura ambiental. As cortinas eram mantidas fechadas durante todo o dia, até a terceira semana, sendo abertas somente no período diurno a partir de então. Em ambas as salas o manejo foi semelhante, respeitando-se os mesmos horários, para evitar alterações entre as salas por motivos outros que não a inoculação experimental. As rações eram adicionadas nos cochos ao longo de todo o dia, quando era notado algum vazio. 
Tabela 1 - Composição em quilogramas das rações experimentais administradas durante o período de creche

\begin{tabular}{|c|c|c|c|c|c|c|c|c|}
\hline \multirow{2}{*}{\multicolumn{2}{|c|}{ Ingredientes (kg }} & & & \multicolumn{5}{|c|}{ Ração Controle } \\
\hline & & & & \multicolumn{2}{|c|}{ Pré inicial } & Inicial I & \multicolumn{2}{|c|}{ Inicial II } \\
\hline \multicolumn{3}{|c|}{ Farelo de soia } & & \multicolumn{2}{|l|}{333,32} & 333,8 & \multicolumn{2}{|r|}{328,0} \\
\hline \multicolumn{3}{|c|}{ Farelo de bolacha } & & \multicolumn{2}{|l|}{120,0} & 60,0 & \multirow{2}{*}{\multicolumn{2}{|c|}{598,0}} \\
\hline \multicolumn{3}{|c|}{ Milho moído } & & \multirow{2}{*}{\multicolumn{2}{|c|}{42864}} & \multirow[b]{2}{*}{533,52} & & \\
\hline \multicolumn{3}{|c|}{ Milho fubá } & & & & & \\
\hline \multicolumn{3}{|c|}{ Soro de leite } & & \multicolumn{2}{|l|}{40,0} & 10,0 & \multirow{2}{*}{\multicolumn{2}{|c|}{185}} \\
\hline \multicolumn{3}{|c|}{ Fosfato bicálcico } & & \multicolumn{2}{|l|}{16,0} & 15,0 & \multirow{2}{*}{\multicolumn{2}{|c|}{$\begin{array}{l}10,0 \\
7,0\end{array}$}} \\
\hline \multicolumn{3}{|c|}{ Calcáreo calcítico } & & & & 5,4 & & \\
\hline \multicolumn{3}{|c|}{ Lactose } & & \multicolumn{2}{|l|}{12,0} & 4,0 & \multirow{2}{*}{\multicolumn{2}{|c|}{40,0}} \\
\hline \multicolumn{3}{|c|}{ Açúcar } & & 30,0 & & 30,0 & & \\
\hline Cloreto & de sódio & & & 3,2 & & 2,6 & & 6,0 \\
\hline Lisina & & & & 2,8 & & 1,4 & & \\
\hline Metioni & & & & 3,6 & & 1,0 & & \\
\hline Fitase & & & & 0,12 & & 0,06 & & \\
\hline Colina & & & & 0,32 & & 0,22 & & \\
\hline Palatab & lizante & & & 8,0 & & 1,0 & & \\
\hline Premix & Vitamínic & & & 2,0 & & 1,0 & & 1,0 \\
\hline Premix & Mineral & & & & & 1,0 & & 1,5 \\
\hline Batida & otal $(\mathrm{kg})$ & & & 1000 & & 1000 & & 1000 \\
\hline $\begin{array}{l}{ }^{*} \text { inclusã } \\
\text { rações in } \\
* * * \text { inclusã } \\
* * * \text { suple } \\
\text { vit } A 10.0 \\
\text { Vit } B_{2} 6 . C \\
\text { pantotên } \\
\text { **** suple } \\
\text { cobre } 20\end{array}$ & $\begin{array}{l}\text { ATB: tilo } \\
\text { icial } 1 \text { e } 2) \text {; } \\
\text { o FITO: } 20 \\
\text { nentação v } \\
00 \text { Ul/g; vit } \\
00 \mathrm{mg} / \mathrm{kg} ; \\
\text { co } 15.000 \\
\text { mentação } \\
000 \text { mg/kg }\end{array}$ & $\begin{array}{l}\text { ina }(100 \mathrm{p} \\
\text { óxido de zi } \\
0 \text { ppm. } \\
\text { tamínica p } \\
\mathrm{D}_{3} 2.000 \mathrm{U} \\
\text { it } \mathrm{B}_{6} 3.000 \\
\mathrm{gg} / \mathrm{kg} \text {; ácid } \\
\text { nineral par } \\
\text { zinco } 100 \text {. }\end{array}$ & $\begin{array}{l}\text { m); sulfato } \\
\text { co (2 ppm). } \\
\text { ra cada } 1,5 \\
\text { g; Vit E } 50 . \\
\mathrm{mg} / \mathrm{kg} ; \text { Vit B } \\
\text { fólico } 3.000 \\
\text { cada } 1 \mathrm{~kg} \\
00 \mathrm{mg} / \mathrm{kg} ; \mathrm{n}\end{array}$ & $\begin{array}{l}\text { de colistir } \\
\mathrm{kg} \text { do } \mathrm{proc} \\
000 \mathrm{mg} / \mathrm{kg} \\
\mathrm{B}_{12} 30.000 \\
0 \mathrm{mg} / \mathrm{kg} ; \mathrm{bi} \\
\text { do produto } \\
\text { manganês }\end{array}$ & $\begin{array}{l}\text { ina (30 ppr } \\
\text { duto (Rovin } \\
\text {; Vit } \mathrm{K}_{3} 2.0 \\
\mathrm{mg} / \mathrm{kg} ; \mathrm{nia} \\
\text { iotina } 200 . \\
\text { (Roligomi> } \\
40.000 \mathrm{mg}\end{array}$ & $\begin{array}{l}\text { m na pré } \\
\text { mix®, DSN } \\
000 \mathrm{mg} / \mathrm{kg} ; \\
\text { cina } 30.00 \\
000 \mathrm{mcg} / \mathrm{k} \\
\mathrm{ix}(\mathrm{DSM}) \\
\mathrm{g} / \mathrm{kg} \text {; iodo }\end{array}$ & $\begin{array}{l}\text { inicial e } 10 \\
\text { ): selênio } \\
\text { Vit } B_{1} 2.00 \\
0 \mathrm{mg} / \mathrm{kg} \text {; á } \\
\mathrm{g} \\
\text { ferro } 100 . \\
.500 \mathrm{mg} / \mathrm{k}\end{array}$ & $\begin{array}{l}10 \text { ppm nas } \\
300 \text { mg/kg; } \\
00 \text { mg/kg; } \\
\text { ácido } \\
.000 \text { mg/kg; } \\
\mathrm{kg} \text {. }\end{array}$ \\
\hline Tabela & $\begin{array}{r}2-\text { Comp } \\
\text { e inic }\end{array}$ & $\begin{array}{l}\text { osição b } \\
\text { al } 2\end{array}$ & natológic & ica calcul & lada das & rações $p$ & ré-inicial & al, inicial 1 \\
\hline Ração & $\begin{array}{c}\text { Matéria } \\
\text { seca } \\
(\%)\end{array}$ & $\begin{array}{c}\text { Energia } \\
\text { bruta } \\
\text { (cal/g) }\end{array}$ & $\begin{array}{c}\text { Proteína } \\
\text { bruta } \\
(\%)\end{array}$ & $\begin{array}{c}\text { Fibra } \\
\text { bruta } \\
(\%)\end{array}$ & $\begin{array}{c}\text { Matéria } \\
\text { mineral } \\
(\%)\end{array}$ & $\begin{array}{c}\text { Cálcio } \\
(\%)\end{array}$ & $\begin{array}{c}\text { Fósforo } \\
(\%)\end{array}$ & $\begin{array}{c}\text { Extrato } \\
\text { Etéreo } \\
(\%)\end{array}$ \\
\hline $\begin{array}{l}\text { Pré } \\
\text { inicial }\end{array}$ & 89,66 & 4341 & 21,62 & 3,55 & 5,26 & 0,58 & 0,52 & 2,68 \\
\hline $\begin{array}{l}\text { Inicial } \\
1\end{array}$ & 89,62 & 4303 & 22,46 & 3,38 & 6,19 & 0,93 & 0,67 & 2,68 \\
\hline $\begin{array}{l}\text { Inicial } \\
2\end{array}$ & 90,21 & 4282 & 21,94 & 5,07 & 7,41 & 0,94 & 0,62 & 3,13 \\
\hline
\end{tabular}




\subsubsection{Desafio experimental}

O desafio foi realizado aos 35 dias de idade dos leitões, com uma amostra de Salmonella typhimurium (LSS90/05). Os animais foram inoculados por via oral com uma concentração de $1 \times 10^{5}$ UFC (unidades formadoras de colônia) da cepa de Salmonella typhimurium supracitada. A sala de creche na qual os leitões foram inoculados (sala desafiada) permaneceu isolada da sala na que os leitões não foram inoculados (sala sem desafio). Para evitar o risco de contaminação cruzada, a partir da inoculação experimental (35 dias de idade) em cada sala, as atividades rotineiras eram realizadas pelos mesmos indivíduos, os quais não entravam em contato com a outra sala. Em cada sala elaborou-se esquema de trabalho de tal forma que houvesse 1 investigador responsável pela alimentação dos animais sendo realizada diariamente análise da consistência das fezes. Ambos passaram por 1 semana de treinamento para a analisar da consistência das fezes, diminuindo o risco de avaliação subjetiva. As rações de cada sala foram separadas evitando o contato entre si, bem como, todos os objetos que por ventura fossem usados no dia-a-dia do experimento.

\subsubsection{Colheita de materiais e análises laboratoriais}

A coleta de material fecal, realizada através de suabes retais em três períodos (aos 35 dias, dia em que fora realizado o desafio experimental; aos 49 dias e aos 63 dias de idade dos leitões), objetivou o isolamento da Salmonella typhimurium, sendo esta análise realizada pelo Laboratório de Sanidade Suína da FMVZ-USP (LSS), em São Paulo, SP. Foram colhidos suabes de fezes de 2 leitões escolhidos ao acaso e identificados de cada gaiola. As amostras coletadas foram submetidas ao protocolo de isolamento previamente descrito (HOLT et al., 1994). Os suabes de fezes foram semeados, em $9 \mathrm{ml}$ de caldo tetrationato com iodo e mantidos a $37^{\circ} \mathrm{C}$ por 24 horas. A partir do tubo de 
enriquecimento seletivo as amostras foram semeadas em agar Xilose Lisina Tergitol-4 (XLT4) e ágar MacConkey. Os meios foram incubados por 24 horas a $37^{\circ} \mathrm{C}$. As colônias lactose negativas em ágar MacConkey e as que apresentaram precipitação de $\mathrm{H}_{2} \mathrm{~S}$ em meio XLT4 foram submetidas às provas bioquímicas para identificação inicial segundo descrito por Quinn et al. (1994). Colônias com resultado bioquímico sugestivo de Salmonella spp. foram submetidas a Reação em Cadeia pela Polimerase (PCR) segundo descrito por Stone et al. (1994). Devido à necessidade de uma etapa de enriquecimento seletivo para melhor isolamento do agente a partir de fezes não foi realizada a contagem de unidades formadoras de colônia, sendo as amostras caracterizadas apenas como positivas ou negativas para o agente.

Foram abatidos 4 animais no início do experimento (dia 0), e 12 animais ao fim do experimento (2 leitões de cada tratamento), sendo enviados fragamentos de linfonodo mesentérico, íleo e cólon para confecção de lâminas e exame histopatológico. Os suabes foram enviados para análise no LSS.

A análise da composição bromatológicas das rações experimentais foi realizada pelo Laboratório de Bromatologia da FMVZ-USP, câmpus de Pirassununga, e está apresentada nas tabelas 2 e 4.

\subsubsection{Variáveis analisadas}

\subsubsection{Variáveis de desempenho}

Os animais foram pesados aos 21, 35, 49 e 63 dias de idade, sendo anotado o consumo de ração. As variáveis de desempenho analisadas foram: peso médio (PM), em quilogramas $(\mathrm{kg})$, aos 21, 35, 49 e 63 dias de idade; ganho diário de peso (GDP), em kg/animal/dia; consumo diário de ração (CDR), em kg/animal/dia, e conversão alimentar (CA). As faixas de idade nas quais GDP, CDR e CA foram calculados foram: dos 21 aos 34 dias de idade; dos 35 aos 48 dias de idade; dos 49 aos 63 dias de idade e no período total da creche (dos 21 aos 63 dias de idade). 


\subsubsection{Histologia do epitélio intestinal}

Foram abatidos 4 animais no início do experimento (dia 0), e 12 animais ao fim do experimento (2 leitões de cada tratamento). Durante a necrópsia foram retirados segmentos do duodeno, jejuno, íleo, ceco e cólon, além de linfonodos mesentéricos que foram fixados em formalina 10\% para posterior análise histopatológica. Após a fixação dos fragmentos, os mesmos foram emblocados em parafina, submetidos a cortes seriados, os quais foram fixados em lâmina e submetidos à coloração por hematoxilina e eosina. As análises das lesões causadas por Salmonella typhimurium nesses fragmentos, foram realizadas pelo Laboratório de Sanidade Suína da FMVZ-USP, em São Paulo, SP. Lá foram identificadas, através de microscopia óptica, lesões correspondentes à infecção por Salmonella typhimurium. Foram ainda identificadas características histológicas distintas nessas lesões, e atribuídos escores de gravidade para essas lesões, sendo: 0 = ausência; 1 = discreto; 2 = moderado e 3 = acentuado.

\subsubsection{Freqüência de diarréia}

Diariamente, dos 21 aos 63 dias de idade, anotou-se a consistência das fezes, atribuíndo-se os seguintes escores: 1 (fezes normais); 2 (fezes pastosas) e 3 (fezes íquidas). Posteriormente, foi analisada a freqüência de dias com diarréia - FDD, (que consiste no quociente entre o número de dias que os animais apresentaram fezes pastosas e fezes líquidas e o número de dias considerados), a freqüência de dias com diarréia líquida (FDD/) e a freqüência de dias com diarréia pastosa (FDDp), nas seguintes faixas de tempo consideradas: 21 a 34 dias de idade; 35 a 48 dias de idade; 49 a 63 dias de idade; e 21 a 63 dias de idade (período total).

\subsubsection{Eliminação fecal de Salmonella typhimurium}


A coleta de material fecal foi realizada através de suabes retais, em três períodos: aos 35 dias (dia em que fora realizado o desafio experimental), aos 49 dias e aos 63 dias de idade para isolamento de Salmonella spp., sendo identificado a presença ou ausência da bactéria. A coleta de material fecal foi realizada em 60 leitões (10 animais/tratamento), sendo realizadas nos três períodos nos mesmos animais.

\subsection{FASE DE CRESCIMENTO E TERMINAÇÃO}

Essa nova etapa do experimento surgiu após questionamentos quanto à evolução do crescimento dos animais, em fases posteriores à da creche. Esse questionamento foi relacionado aos possíveis ganhos compensatórios motivados pela ação não direta dos fitoterápicos em relação aos antibióticos.

\subsubsection{Animais e instalações e delineamento experimental}

Os animais utilizados nessa etapa do experimento foram os mesmos oriundos da creche, totalizando 99 leitões. Dos 124 leitões iniciais, 4 foram abatidos aos 21 dias de idade, 12 foram abatidos no dia 63, e 5 vieram à óbito. Durante a transferência para terminação, 4 animais foram descartados do experimento, para manter o mesmo número de leitões por tratamento. $O$ delineamento da creche, inteiramente casualizado, com arranjo fatorial 3X2 dos tratamentos foi conservado havendo a distribuíção em três tratamentos: antibiótico (ATB), controle (CTRL) e fitocomposto (FITO). O diferencial com a creche foi a não inclusão de um novo desafio com bactérias patogênicas, mantendo-se, no entanto, a divisão entre animais desafiados e não desafiados em salas distintas. As instalações utilizadas pertencem à unidade de crescimento e terminação do Laboratório de Pesquisa em Suínos (LPS), da Faculdade de Medicina Veterinária e Zootecnia da Universidade de São Paulo (FMVZ-USP), Câmpus de Pirassununga. Essas instalações contam com 
comedouro individual, bebedouro tipo chupeta e são providas com lâmina d'água para propiciar melhor conforto térmico aos animais. Os animais permaneceram na instalação dos 63 dias até os 131 dias de idade quando foram abatidos.

\subsubsection{Alimentação}

A água e a alimentação foram fornecidas ad libitum aos leitões. As formulações foram semelhantes às empregadas comercialmente nas criações, sendo fornecidas pela Granja Santa Rosa (Leme, SP), havendo somente a suplementação ou não do fito composto, ou de antibiótico em dosagens como promotor de crescimento (sulfato de colistina, tilosina e óxido de zinco, respectivamente na dosagem de 5, 100 e 2 ppm). As rações utilizadas foram: crescimento (dos 63 a 105 dias de idade) e terminação (dos 105 aos 131 dias de idade). As rações experimentais obedeceram à composição de ingredientes e aos níveis bromatológicos explicitados respectivamente nas tabelas 3 e 4 . 0 fito composto utilizado foi o mesmo da fase de creche, na mesma dosagem. Optou-se por excluir das rações a substância ractopamina, utilizada comumente nas rações comerciais na fase de terminação, para evitar possível efeito de confundimento com os aditivos a serem testados. 
Tabela 3 - Composição em quilogramas das rações experimentais administradas durante o período de crescimento e terminação

\begin{tabular}{|c|c|c|}
\hline \multirow[b]{2}{*}{ Ingredientes (kg) } & \multicolumn{2}{|c|}{ Ração Controle } \\
\hline & Crescimento & Terminação 1 \\
\hline Milho & 620,13 & 636,41 \\
\hline Farelo de arroz & 87,09 & 117,84 \\
\hline Gordura animal & 3,48 & 5,66 \\
\hline Farelo de soja $45 \%$ & 236,44 & 189,01 \\
\hline Farelo de carne $42 \%$ & 18,72 & 12,25 \\
\hline Cloreto de sódio & 4,09 & 4,43 \\
\hline Levedura de cana (rolo) & 8,71 & 9,43 \\
\hline Calcáreo calcítico & 5,23 & 7,54 \\
\hline Premix mineral & 2,18 & 2,36 \\
\hline Premix vitamínico & 4,35 & 4,01 \\
\hline Dl-metionina & 0,87 & \\
\hline L-lisina & 5,66 & 6,36 \\
\hline Treonina & & 1,18 \\
\hline Colina & 0,87 & 1,18 \\
\hline Complexo multienzimático & 2,18 & 2,36 \\
\hline Batida Total (kg) & 1000 & 1000 \\
\hline $\begin{array}{l}\text { * inclusão ATB: tilosina (100 ppm) } \\
{ }^{* *} \text { inclusão FITO: } 2.000 \text { ppm; } \\
{ }^{* * *} \text { suplementação vitamínica para } \\
\mathrm{mg} / \mathrm{kg} \text {; vit A } 2.880 \mathrm{Ul} / \mathrm{g} ; \text { vit } D_{3} 585 \\
\text { Vit } B_{2} 2.520 \mathrm{mg} / \mathrm{kg} ; \mathrm{Vit} \mathrm{B}_{6} 540 \mathrm{mg} / \\
\text { pantotênico } 8.400 \mathrm{mg} / \mathrm{kg} \text {; ácido fól } \\
\text { *** suplementação mineral para c } \\
\mathrm{mg} / \mathrm{kg} \text {; cobre } 14.400 \mathrm{mg} / \mathrm{kg} \text {; zinco }\end{array}$ & $\begin{array}{l}\text { tina (5 ppm); óxido } \\
\text { produto (Engorda } \\
0 \mathrm{mg} / \mathrm{kg} ; \text { Vit } \mathrm{K}_{3} 90 \\
\mathrm{mg} / \mathrm{kg} ; \text { niacina } 14 \\
\text { antioxidante } 170 \mathrm{~m} \\
\text { duto (Micromineral } \\
\text { manganês } 27.000\end{array}$ & $\begin{array}{l}\text { co (2 ppm) } \\
\text { Nutron): selênio } 270 \\
\text { g; Vit } B_{1} 450 \mathrm{mg} / \mathrm{kg} ; \\
\text { g/kg; ácido } \\
\text { ron): ferro } 99.000 \\
\text {; iodo } 540 \mathrm{mg} / \mathrm{kg} \text {. }\end{array}$ \\
\hline
\end{tabular}

Tabela 4 - Composição bromatológica calculada das rações crescimento e terminação

\begin{tabular}{lcccccccc}
\hline \multirow{2}{*}{ Ração } & $\begin{array}{c}\text { Matéria } \\
\text { seca } \\
(\%)\end{array}$ & $\begin{array}{c}\text { Energia } \\
\text { bruta } \\
(\mathrm{cal} / \mathrm{g})\end{array}$ & $\begin{array}{c}\text { Proteína } \\
\text { bruta } \\
(\%)\end{array}$ & $\begin{array}{c}\text { Fibra } \\
\text { bruta } \\
(\%)\end{array}$ & $\begin{array}{c}\text { Matéria } \\
\text { mineral } \\
(\%)\end{array}$ & $\begin{array}{c}\text { Cálcio } \\
(\%)\end{array}$ & $\begin{array}{c}\text { Fósforo } \\
(\%)\end{array}$ & $\begin{array}{c}\text { Extrato } \\
\text { Etéreo } \\
(\%)\end{array}$ \\
\hline Crescimento & 86,91 & 4491 & 21,86 & 3,63 & 6,89 & 1,01 & 0,67 & 6,49 \\
\hline Terminação & 86,50 & 4512 & 18,08 & 3,53 & 5,66 & 0,79 & 0,57 & 6,29 \\
\hline
\end{tabular}

\subsubsection{Variáveis analisadas}

\subsubsection{Variáveis de desempenho}

Todos os 99 animais foram pesados aos 96, 105 e 131 dias de idade, sendo anotado o consumo de ração. As variáveis de desempenho analisadas 
foram: peso médio (PM), em quilogramas $(\mathrm{kg})$, aos 96, 105 e 131 dias de idade; ganho diário de peso (GDP), em kg/animal/dia; consumo diário de ração (CDR), em kg/animal/dia, e conversão alimentar (CA). As faixas de idade nas quais GDP, CDR e CA foram calculados foram: 63 a 96 dias (início da fase de crescimento); 96 a 105 dias (final da fase de crescimento); e 105 a 131 dias (fase de terminação).

\subsubsection{Estabilidade oxidativa da gordura intramuscular}

$\mathrm{Na}$ ocasião do abate, aos 131 dias de idade, 9 animais (totalizando 3 animais por tratamento) foram submetidos à análise de carcaça para verificação da atividade antioxidativa do fitocomposto. Para se evitar qualquer efeito de confundimento com o fator desafio, todos os animais foram oriundos da sala não desafiada durante o período de creche. Para tanto, foi utilizada a metodologia denominada TBARS (substâncias reativas ao ácido tiobarbitúrico). A reação dessas substâncias com a gordura intramuscular libera malondialdeído, produzido em reação ao estresse oxidativo sofrido pelo tecido, que é identificado por espectrofotometria. Assim, quanto maior a quantidade de malondialdeído (dado em $\mathrm{mg} / \mathrm{kg}$ de músculo), menor é a resistência da gordura intramuscular à oxidação.

\subsubsection{Colheita de materiais e análises laboratoriais}

Foi coletado tecido muscular de 9 animais da sala não desafiada (totalizando três animais do grupo FITO, CTRL e ATB), para a análise da resistência da gordura intramuscular à oxidação, através da metodologia TBARS (substâncias reativas ao ácido tiobarbitúrico). Essa substância, identificada por espectrofotometria, é produzida em reação ao estresse oxidativo sofrido pelo tecido. Assim, quanto maior a quantidade de malondialdeído (dado em $\mathrm{mg} / \mathrm{kg}$ de músculo), menor é a resistência da gordura 
intramuscular à oxidação. Foram coletados fragmentos do músculo longissimus dorsi, entre a quinta e sexta vértebras lombares (4 amostras por animal), todas retiradas do lado esquerdo da carcaça. A coleta foi realizada 1 hora após o abate. Imediatamente após a coleta, estes fragmentos de músculo foram embrulhados em papel alumínio devidamente identificados e congelados em nitrogênio líquido, mantidos à temperatura de $-80^{\circ} \mathrm{C}$ até a análise. A resistência da gordura presente no músculo em resistir à oxidação é avaliada através da quantidade de malondialdeído produzido pelo tecido. As amostras trituradas e homogeneizadas foram analisadas para substâncias reativas ao ácido 2tiobarbitúrico (TBARS), conforme metodologia proposta por Vyncke et al. (1970). Para esta análise inicialmente preparou-se uma solução de ácido tricloroácetico (TCA) 7,5\% contendo 1\% de EDTA e 1\% de propilgalato, e uma solução de ácido 2-tiobarbitúrico (TBA) 0,02M. Todos os reagentes utilizados foram da marca Sigma. Foram pesados $5 \mathrm{~g}$ de músculo, que foram homogeneizados em $25 \mathrm{~mL}$ de solução de TCA 7,5\% por 30 segundos a 18000 rpm, utilizando-se homogeneizador Turratec (modelo TE-102; marca Tecnal). A solução foi filtrada em papel de filtro Whatman no 1. Coletou-se $5 \mathrm{~mL}$ do filtrado, ao qual foi adicionado $5 \mathrm{~mL}$ da solução de TBA 0,02M. Os tubos foram levados a banho-maria fervente por $40 \mathrm{~min}$, depois de frias as amostras foram lidas em espectrofotômetro (mod. DU 640, marca Beckman) a $538 \mathrm{~nm}$. Preparou-se também uma curva com 5 pontos utilizando-se uma solução de tetrametoxipropano (TMP) de concentração conhecida. Para obter-se a concentração de malonaldeído nas amostras utilizou-se a equação fornecida pela curva. A análise foi realizada pelo Laboratório de Neurociência e Proteômica, da Faculdade de Zootecnia e Engenharia de Alimentos (USP, Campus de Pirassununga).

\subsection{ANÁLISE ESTATÍSTICA}

O delineamento experimental adotado foi inteiramente casualizado, tanto na fase de creche quanto de crescimento e terminação, com arranjo fatorial $3 \times 2$, sendo um fator o uso de substâncias promotoras de crescimento na ração 
(ADITIVO) e outro fator o desafio (SALA), obedecendo ao seguinte modelo matemático: Yijk $=\mu+a_{i}+s_{j}+a_{i}{ }^{*} s_{j}+e_{i j k}$, o qual incluiu os fatores aditivo (a), sala (s), interação entre aditivo e sala ( $\left.a^{*} s\right)$ e o erro experimental (e). A unidade experimental foi a baia, havendo 5 repetições por tratamento.

A consistência das fezes foi anotada diariamente, durante a fase de creche. Os dados referentes à freqüência em dias com diarréia, à freqüência em dias com diarréia pastosa e freqüência em dias com diarréia líquida foram submetidos à transformação pela função $y=\operatorname{arcsen} \sqrt{ }(p / 100)$, sendo "p" a porcentagem de dias com diarréia, de acordo com Banzatto e Kronka (1989) e Barbin et al. (2003), de modo a tornar a variância destes dados mais homogênea.

As variáveis de desempenho e freqüência de diarréia foram submetidas à analise de variância pelo procedimento General Linear Models (PROC GLM), e os tratamentos foram comparados entre si através do teste de Tukey, sendo anteriormente verificada a normalidade dos resíduos pelo teste de Shapiro-Wilk (PROC UNIVARIATE) e a homogeneidade das variâncias. Variáveis que não respeitaram essas premissas estatísticas foram transformadas pelas funções logarítmica $(y=\log x)$, raiz quadrada $(y=\sqrt{x}+1 / 2)$ ou inversa $(y=1 / x)$, onde $x$ é a variável a ser transformada. A concentração de malonaldeído no tecido muscular foi submetida à análise estatística semelhante às variáveis de desempenho, com a diferença de que não foi levado em conta o fator sala (todos os leitões foram oriundos da sala não desafiada).

A eliminação fecal de Salmonella typhimurium foi analisada através do teste exato de Fisher. Para análise do grau das lesões histopatológicas foi utilizado o teste de Kruskal-Walis. Para as análises foi utilizado o programa computacional SAS O nível de significância usado foi de $5 \%$. 
RESULTADOS E DISCUSSÃO 


\section{RESULTADOS E DISCUSSÃO}

\subsection{TEMPERATURA MÉDIA DAS SALAS}

Diariamente, durante o período da manhã, a temperatura mínima e máxima de cada sala foi aferida através de um termômetro de mínima e máxima de bulbo seco. Os resultados são mostrados na tabela 5 . Não houve diferenças entre a temperatura da sala desafiada e não desafiada.

Tabela 5 - Média das temperaturas mínimas e máximas, e da amplitude de temperatura em diferentes semanas $\left(\mathrm{em}^{\circ} \mathrm{C}\right)$

\begin{tabular}{lrrr}
\hline Idade (dias) & $\mathbf{T}^{\circ}$ mínima média & $\mathbf{T}^{\circ}$ máxima média & Amplitude média \\
\hline $\mathbf{2 1}-\mathbf{2 7}$ & 16,4 & 27,3 & 10,9 \\
$\mathbf{2 8}-\mathbf{3 4}$ & 20,7 & 29,9 & 9,1 \\
$\mathbf{3 5}-\mathbf{4 1}$ & 21,9 & 32,7 & 10,8 \\
$\mathbf{4 2}-\mathbf{4 8}$ & 21,4 & 31,3 & 9,4 \\
$\mathbf{4 9}-\mathbf{5 5}$ & 23,2 & 33,2 & 9,9 \\
$\mathbf{5 6}-\mathbf{6 3}$ & 21,1 & 30,0 & 8,8 \\
\hline
\end{tabular}

\subsection{DESEMPENHO}

\subsubsection{Peso médio (PM)}

A tabela 6 apresenta os valores médios e desvios-padrão das características relacionadas ao peso médio (PM) aos 21, 35, 49 e 63 dias de idade (período de creche), e a tabela 7 revela os valores de PM aos 63 (início da fase de crescimento), 96 (final da fase de crescimento), 106 (transição entre a fase de crescimento e terminação) e 131 dias de idade (fase de terminação). A tabela 8 apresenta os valores de peso médio dos leitões alocados nos 6 tratamentos e os respectivos coeficientes de variação, aos 49 e 63 dias de idade. O peso médio dos animais aos 
21 dias de idade, não diferiu em nenhum dos grupos, o que refletiu a pequena variabilidade dos animais nas unidades experimentais e conseqüentemente nos tratamentos. Assim, não houve necessidade da distribuição em blocos, comum em vários experimentos envolvendo leitões na fase de creche.

Os valores contidos nas tabelas 6 e 7 evideciaram que leitões recebendo ATB apresentaram maior peso médio durante a fase de creche, início e final da fase de crescimento e transição entre crescimento e terminação, em relação aos que não receberam aditivos à ração (CTRL) e o grupo FITO. No entanto, conforme mostra a tabela 7, aos 96 dias, o PM dos leitões no grupo controle não diferiu estatisticamente de ATB e FITO, enquanto PM de ATB foi significativamente maior que FITO. Aos 131 dias de idade, o peso médio nos três grupos não diferiu estatisticamente entre si, apesar de, numericamente, o peso médio do grupo ATB ter sido maior que o CTRL e FITO $(92,5 \pm 4,1,90,5 \pm 4,1$ e $88,4 \pm 5,9 \mathrm{~kg}$, respectivamente). Portanto, comparativamente às outras idades em que o ATB mostrou-se com valor significativamente maior em relação ao FITO, pode-se identificar uma modificação de significância observada, havendo a possibilidade de um ganho compensatório do grupo FITO. Alguns autores observaram menor peso de suínos recebendo extratos herbáceos em relação a animais que não receberam aditivos na ração (NAMKUNG et al., 2004), sendo esse efeito atribuído a uma diminuição no consumo alimentar ocasionada por essas substâncias. No presente estudo, não houve diferenças significativas entre FITO e CTRL em relação ao consumo alimentar em nenhuma das faixas (Tabelas 6 e 7). Dos 96 aos 105 dias de idade houve diferença numérica entre o CDR de FITO e CTRL, sendo FITO numericamente menor que CTRL $(2,67 \pm 0,16$ vs $2,82 \pm 0,15$, respectivamente, $p=0,11)$. No entanto, como a diferença entre o PM de FITO e CTRL já estava presente aos 96 dias de idade, esse menor consumo de FITO nesse período não pode ser relacionado a seu menor PM.

Com relação ao efeito de desafio, o PM dos animais, que não apresentava diferenças entre as salas até o início do período de crescimento, passou a apresentar significância, revelando valor maior na sala que não recebeu inoculação de Salmonella typhimurium durante a creche, aos 106 dias de idade (Tabelas 6 e 7). A melhora no desempenho no período de crescimento e terminação dos animais desafiados durante a fase de creche que ocorreu com relação ao consumo diário de ração será comentada no item 5.2.3 dos resultados e discussão.

Interessante notar também que, em uma situação de desafio, o PM do grupo 
FITO apresentou menor variabilidade ao final da creche (49 e 63 dias), explicitada pelo desvio padrão e coeficiente de variação $(\mathrm{CV})$, conforme a tabela 8 . Comparando os 6 tratamentos entre si, O CV dos animais recebendo FITO, na sala desafiada, foi pelo menos a metade do $\mathrm{CV}$ dos leitões nos outros tratamentos aos 49 dias de idade (CV do grupo FITO na sala desafiada foi de $4,2 \%$, enquanto que dos outros 5 tratamentos variou de 8,87 a 13,43\%), e um quarto do CV dos leitões nos outros tratamentos aos 63 dias de idade (CV dos leitões recebendo FITO, na sala desafiada foi de 2,8\%, enquanto que nos outros 5 tratamentos variou de 7,19 a 11,89\%) (Tabela 8). Essa menor variabilidade é interessante ser justificada do ponto de vista produtivo. Uma melhor homogeneidade em termos de peso dos lotes diminui a chance de ocorrer refugagem, além de propiciar carcaças mais homogêneas, promovendo um melhor processamento e tipificação das carcaças no frigorífico. Não foram encontrados na literatura trabalhos que avaliassem a ação dos compostos à base de ervas sobre a homogeneidade de tamanho de suínos.

Outro aspecto importante a se considerar é o peso médio final (aos 131 dias de idade), que não mostrou diferenças significativas entre os tratamentos, podendo de certa forma explicar o desempenho diferencial do fito composto, com ação mais sutil, revelada pelos efeitos indiretos com o agente antimicrobiano, diferentemente do efeito do antibiótico, com ação mais efetiva direta. Esse diferencial começou a se mostrar no período de 49 a 63 dias, em que as diferenças entre FITO e ATB foram menores quanto ao ganho de peso como reflexo do consumo diferenciado. $\mathrm{Na}$ realidade averigua-se no estudo os diferencias de resposta observados nesses dois períodos citados. 
Tabela 6 - Valores médios e desvios padrão da variável peso médio (PM), em quilogramas, de leitões dos 21 aos 34 , 35 aos 48 , 49 aos 63 e 21 aos 63 dias de idade, recebendo na dieta fito composto (FITO), antibiótico (ATB) ou sem aditivo algum na dieta (CTRL), nas salas desafiadas (D) ou não desafiadas (SD)

\begin{tabular}{|c|c|c|c|c|c|c|c|c|}
\hline \multirow[b]{2}{*}{ Período } & \multirow[b]{2}{*}{ Sala } & \multicolumn{3}{|c|}{ Aditivos } & \multirow[b]{2}{*}{ Médias $^{2}$} & \multicolumn{3}{|c|}{$\mathbf{P}$} \\
\hline & & FITO & CTRL & ATB & & aditivo & sala & aditivo*sala \\
\hline 21 dias & SD & $5,7 \pm 0,50$ & $5,8 \pm 0,43$ & $5,7 \pm 0,48$ & $5,81 \pm 0,44$ & ns & ns & ns \\
\hline \multirow[t]{2}{*}{35 dias } & $\mathrm{D}$ & $8,3 \pm 0,63$ & $8,3 \pm 0,77$ & $9,7 \pm 1,06$ & $8,8 \pm 1,05$ & \multirow[t]{3}{*}{0,0006} & \multirow[t]{3}{*}{ ns } & \multirow[t]{3}{*}{ ns } \\
\hline & SD & $8,2 \pm 0,93$ & $8,3 \pm 0,52$ & $9,7 \pm 0,98$ & $8,7 \pm 1,06$ & & & \\
\hline Médias $^{1}$ & & $8,2 \pm 0,75^{b}$ & $8,3 \pm 0,62^{b}$ & $9,7 \pm 0,96^{a}$ & & & & \\
\hline Médias $^{1}$ & & $14,8 \pm 0,41^{b}$ & $15,1 \pm 1,39^{b}$ & $18,4 \pm 1,56^{a}$ & & $<0,0001$ & ns & ns \\
\hline \multirow[t]{3}{*}{63 dias } & $\mathrm{D}$ & $23,4 \pm 0,65$ & $23,6 \pm 2,05$ & $27,2 \pm 1,96$ & $24,7 \pm 2,40$ & \multirow[t]{3}{*}{0,0005} & \multirow[t]{3}{*}{ ns } & \multirow[t]{3}{*}{$\mathrm{ns}$} \\
\hline & SD & $22,5 \pm 2,67$ & $23,7 \pm 1,70$ & $27,1 \pm 2,62$ & $24,4 \pm 3,01$ & & & \\
\hline & & $22,9 \pm 1,90^{b}$ & $23,6 \pm 1,78^{b}$ & $27,2 \pm 2,18^{a}$ & & & & \\
\hline
\end{tabular}

Médias seguidas de letras minúsculas diferentes na mesma linha ou de letras maiúsculas na mesma coluna diferem entre si pelo teste de Tukey $(P<0,05)$.

Média ${ }^{1}$ : médias obtidas pelos diferentes aditivos

Média ${ }^{2}$ : médias obtidas em cada sala

P: probabilidades.

Ns: não significativo 
Tabela 7 - Valores médios e desvios padrão da variável peso médio (PM), em quilogramas, de leitões aos 63, 96,106 e 131 dias de idade, recebendo na dieta fito composto (FITO), antibiótico (ATB) ou sem aditivo algum na dieta (CTRL), nas salas desafiadas (D) ou não desafiadas (SD)

\begin{tabular}{|c|c|c|c|c|c|c|c|c|}
\hline \multirow[b]{2}{*}{ Período } & \multirow[b]{2}{*}{ Sala } & \multicolumn{3}{|c|}{ Aditivos } & \multirow[b]{2}{*}{ Médias $^{2}$} & \multicolumn{3}{|c|}{$\mathbf{P}$} \\
\hline & & FITO & CTRL & ATB & & aditivo & sala & aditivo*sala \\
\hline \multirow[t]{2}{*}{63 dias } & $\mathrm{D}$ & $23,4 \pm 0,65$ & $23,6 \pm 2,05$ & $27,2 \pm 1,96$ & $24,7 \pm 2,40$ & 0,0005 & ns & ns \\
\hline & SD & $22,5 \pm 2,67$ & $23,7 \pm 1,70$ & $27,1 \pm 2,62$ & $24,4 \pm 3,01$ & & & \\
\hline Médias $^{1}$ & & $22,9 \pm 1,90^{b}$ & $23,6 \pm 1,78^{b}$ & $27,2 \pm 2,18^{a}$ & & & & \\
\hline \multirow[t]{2}{*}{96 dias } & $\mathrm{D}$ & $54,0 \pm 1,94$ & $54,9 \pm 2,31$ & $56,6 \pm 3,81$ & $55,2 \pm 2,84$ & 0,009 & ns & ns \\
\hline & SD & $50,9 \pm 3,13$ & $54,2 \pm 2,86$ & $56,9 \pm 2,74$ & $54,0 \pm 3,70$ & & & \\
\hline Médias $^{1}$ & & $52,5 \pm 2,94^{b}$ & $54,5 \pm 2,48{ }^{a b}$ & $56,8 \pm 3,13^{a}$ & & & & \\
\hline \multirow[t]{2}{*}{106 dias } & $\mathrm{D}$ & $67,2 \pm 2,94$ & $67,1 \pm 2,71$ & $69,0 \pm 3,41$ & $67,8 \pm 2,95^{A}$ & 0,008 & 0,005 & ns \\
\hline & SD & $60,4 \pm 2,92$ & $63,5 \pm 3,94$ & $68,4 \pm 3,41$ & $64,1 \pm 4,66^{B}$ & & & \\
\hline Médias $^{1}$ & & $63,8 \pm 4,54^{b}$ & $65,3 \pm 3,69^{a b}$ & $68,7 \pm 3,24^{a}$ & & & & \\
\hline \multirow[t]{2}{*}{131 dias } & $\mathrm{D}$ & $90,7 \pm 4,42$ & $92,1 \pm 2,74$ & $91,5 \pm 6,08$ & $91,4 \pm 4,15$ & $\mathrm{~ns}$ & ns & ns \\
\hline & SD & $86,1 \pm 6,89$ & $88,9 \pm 4,83$ & $93,4 \pm 2,07$ & $89,4 \pm 5,58$ & & & \\
\hline Médias $^{1}$ & & $88,4 \pm 5,98$ & $90,5 \pm 4,08$ & $92,5 \pm 4,12$ & & & & \\
\hline
\end{tabular}

Médias seguidas de letras minúsculas diferentes na mesma linha ou de letras maiúsculas na mesma coluna diferem entre si pelo teste de Tukey (P<0,05).

Média ${ }^{1}$ : médias obtidas pelos diferentes aditivos

Média ${ }^{2}$ : médias obtidas em cada sala

P: probabilidades.

Ns: não significativo 
Tabela 8 - Valores médios dos pesos médios (PM), expressos em quilogramas, e respectivos coeficientes de variação $(\mathrm{CV})$, expressos em porcentagem, dos leitões aos 49 e 63 dias de idade, nos tratamentos fito composto (FITO), antibiótico (ATB) e controle (CTRL), nas salas desafiada e não desafiada

\begin{tabular}{|c|c|c|c|c|c|c|c|}
\hline \multirow{2}{*}{ Idade } & \multirow[b]{3}{*}{ PM (kg) } & \multicolumn{3}{|c|}{ Sala desafio } & \multicolumn{3}{|c|}{ Sala sem desafio } \\
\hline & & FITO & CTRL & ATB & FITO & CTRL & ATB \\
\hline 19 diac & & 15,17 & 14,96 & 18,13 & 14,53 & 15,35 & 18,68 \\
\hline 49 alas & CV (\%) & 4,19 & 9,86 & 8,90 & 13,43 & 9,46 & 8,87 \\
\hline 63 & PM (kg) & 23,47 & 23,60 & 27,29 & 22,50 & 23,70 & 27,18 \\
\hline os allas & CV (\%) & 2,80 & 8,70 & 7,19 & 11,89 & 7,21 & 9,66 \\
\hline
\end{tabular}

\subsubsection{Ganho diário de peso (GDP)}

As tabelas 9 e 10 apresentam os valores médios e desvios-padrão das características relacionadas ao ganho diário de peso (GDP) dos 21 aos 34,35 aos 48 e 49 aos 63 dias de idade (Tabela 9), e dos 63 aos 95, dos 96 aos 105 e dos 106 aos 131 dias de idade (tabela 10).

Dos 21 a 34 dias e dos 35 aos 48 dias de idade (primeira e segunda quinzenas na creche), GDP do grupo ATB foi maior que de FITO e CTRL. A partir dos 49 aos 63 dias (terceira quinzena de creche), o GDP passa a não mais ser influenciado pelos aditivos, de modo que o GDP de FITO, ATB e CTRL não diferenciaram estatisticamente entre $\mathrm{si}$, mantendo essa situação até o final do experimento (131 dias de idade). Essa mesma tendência foi observada com relação ao CDR (maior para o grupo ATB em relação ao FITO e CTRL durante as duas primeiras quinzenas de creche, deixando de haver significância entre os três aditivos durante a última quinzena de creche, situação que se manteve até os 131 dias), podendo se inferir que o maior CDR do grupo ATB contribuiu para o melhor GDP.

Esses resultados são semelhantes aos obtidos por Namkung et al. (2004). Os autores compararam o desempenho de leitões desmamados com idade média de 17,5 dias (4,9 kg de peso vivo) recebendo mistura de extratos herbáceos de canela, orégano e tomilho com leitões recebendo lincomicina (110 ppm) ou não recebendo aditivos na dieta (controle). Na segunda semana após o desmame, o GDP dos leitões recebendo extratos herbáceos foi significativamente menor que nos leitões 
recebendo lincomicina, não diferindo dos animais do grupo controle. Na terceira semana do experimento, no entanto, o GDP do grupo controle se igualou ao do grupo recebendo lincomicina, e ambos foram significativamente superiores ao grupo que recebeu os extratos herbáceos. Na quarta semana, o GDP dos três grupos não diferiu significativamente. Esses resultados são interessantes quando se compara a ação específica do antibiótico com a da maioria das ervas medicinais, uma vez que se observam ações diferenciais que se mostram mais diretas, no caso dos antibióticos, e mais indiretas e sutis no que envolve ervas medicinais.

Dos 96 a 105 dias de idade dos leitões, período correspondente ao final da fase de crescimento, houve significância do efeito de sala (o GDP dos animais que receberam desafio durante a fase de creche foi 250 gramas superior), conforme mostrado na tabela 10. Apesar de não haver efeito de aditivo ou interação entre desafio e aditivo nessa fase, é interessante notar que, numericamente, na sala que fora desafiada, o GDP do grupo FITO foi superior que o CTRL e o ATB (diferença 100 gramas entre FITO e CTRL), o que indicou um aumento considerável no GDP entre os animais que foram desafiados e alocados no grupo FITO em relação aos no ATB e CTRL. Apesar dessa diferença ser apenas numérica, é essencial análises mais aprofundadas sobre o efeito do fito composto; no item 5.2.5, esses resultados serão melhor abordados. 
Tabela 9 - Valores médios e desvios padrão da variável ganho diário de peso (GDP), em quilogramas/animal/dia, de leitões dos 21 aos 34, 35 aos 48, 49 aos 63 e 21 aos 63 dias de idade, recebendo na dieta fito composto (FITO), antibiótico (ATB) ou sem aditivo algum na dieta (CTRL), nas salas desafiadas (D) ou não desafiadas (SD)

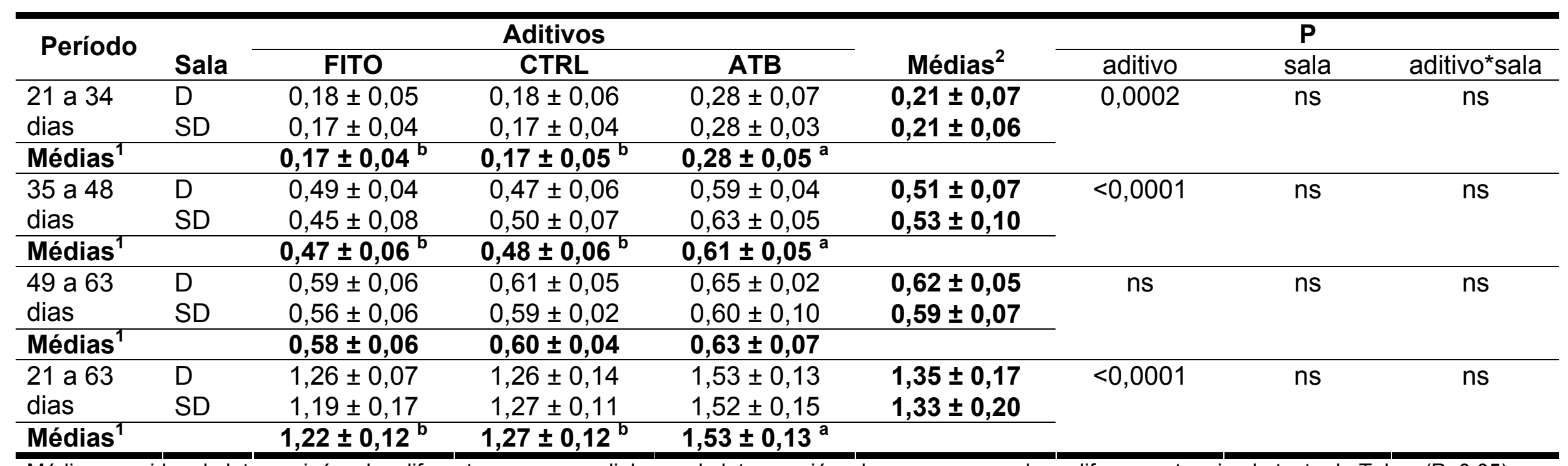

Médias seguidas de letras minúsculas diferentes na mesma linha ou de letras maiúsculas na mesma coluna diferem entre si pelo teste de Tukey $(P<0,05)$.

Média ${ }^{1}$ : médias obtidas pelos diferentes aditivos

Média': médias obtidas em cada sala

$\mathrm{P}$ : probabilidades.

Ns: não significativo 
Tabela 10 - Valores médios e desvios padrão da variável ganho diário de peso (GDP), em quilogramas/animal/dia, de leitões dos 63 aos 95, 96 aos 105, 106 aos 131 e 63 aos 131 dias de idade, recebendo na dieta fito composto (FITO), antibiótico (ATB) ou sem aditivo algum na dieta (CTRL), nas salas desafiadas (D) ou não desafiadas (SD)

\begin{tabular}{|c|c|c|c|c|c|c|c|c|}
\hline \multirow[b]{2}{*}{ Período } & \multirow[b]{2}{*}{ Sala } & \multicolumn{3}{|c|}{ Aditivos } & \multirow[b]{2}{*}{ Médias $^{2}$} & \multicolumn{3}{|c|}{$\mathbf{P}$} \\
\hline & & FITO & CTRL & ATB & & aditivo & sala & aditivo*sala \\
\hline 63 a 95 & $\mathrm{D}$ & $0,92 \pm 0,05$ & $0,95 \pm 0,04$ & $0,89 \pm 0,07$ & $0,92 \pm 0,05$ & ns & ns & $\mathrm{ns}$ \\
\hline dias & SD & $0,86 \pm 0,09$ & $0,92 \pm 0,07$ & $0,90 \pm 0,02$ & $0,89 \pm 0,07$ & & & \\
\hline Médias $^{1}$ & & $0,89 \pm 0,08$ & $0,93 \pm 0,05$ & $0,89 \pm 0,05$ & & & & \\
\hline 96 a 105 & $\mathrm{D}$ & $1,32 \pm 0,16$ & $1,22 \pm 0,15$ & $1,24 \pm 0,14$ & $1,26 \pm 0,15^{A}$ & ns & 0,0002 & ns \\
\hline dias & SD & $0,94 \pm 0,20$ & $0,93 \pm 0,14$ & $1,14 \pm 0,10$ & $1,01 \pm 0,17^{B}$ & & & \\
\hline Médias $^{1}$ & & $1,13 \pm 0,26$ & $1,07 \pm 0,20$ & $1,19 \pm 0,13$ & & & & \\
\hline 106 a 131 & $\mathrm{D}$ & $0,97 \pm 0,14$ & $1,04 \pm 0,03$ & $0,94 \pm 0,14$ & $0,99 \pm 0,11$ & ns & ns & ns \\
\hline dias & SD & $1,07 \pm 0,23$ & $1,05 \pm 0,13$ & $1,04 \pm 0,11$ & $1,05 \pm 0,15$ & & & \\
\hline Médias $^{1}$ & & $1,02 \pm 0,18$ & $1,04 \pm 0,09$ & $0,99 \pm 0,12$ & & & & \\
\hline 63 a 131 & $\mathrm{D}$ & $0,97 \pm 0,14$ & $1,04 \pm 0,03$ & $0,94 \pm 0,14$ & $0,99 \pm 0,11$ & ns & ns & ns \\
\hline dias & SD & $1,07 \pm 0,23$ & $1,05 \pm 0,13$ & $1,04 \pm 0,11$ & $1,05 \pm 0,15$ & & & \\
\hline Médias $^{1}$ & & $1,02 \pm 0,18$ & $1,04 \pm 0,09$ & $0,99 \pm 0,12$ & & & & \\
\hline
\end{tabular}

Médias seguidas de letras minúsculas diferentes na mesma linha ou de letras maiúsculas na mesma coluna diferem entre si pelo teste de Tukey (P<0,05). Média ${ }^{1}$ : médias obtidas pelos diferentes aditivos

Média ${ }^{2}$ : médias obtidas em cada sala

P: probabilidades.

Ns: não significativo 


\subsubsection{Consumo diário de ração (CDR)}

As tabelas 11 e 12 apresentam os valores médios e desvios-padrão das características relacionadas ao consumo diário de ração (CDR) dos 21 aos 34, dos 35 aos 48 e dos 49 aos 63 dias de idade (tabela 11), e dos 63 aos 95, dos 96 aos 105 e dos 106 aos 131 dias de idade (Tabela 12).

Com relação ao efeito de aditivos, observou-se maior CDR no grupo ATB em relação a FITO e CTRL nas duas primeiras quinzenas de creche (dos 21 aos 34 e dos 35 aos 48 dias de idade), seguido por um diferencial tanto do grupo FITO quanto CTRL em relação ao ATB na terceira quinzena de creche (49 aos 63 dias de idade), verificando-se o valor de CDR não significativo entre FITO, CTRL e ATB até os 131 dias de idade. Os resultados relativos ao CDR na creche foram semelhantes aos obtidos por Namkung et al. (2004) e Lovatto et al. (2005). Estes autores observaram que a diferença no desempenho de leitões recebendo extratos herbáceos em relação aos recebendo antimicrobianos ocorreram somente após decorridas as primeiras semanas de administração dos aditivos.

Namkung et al. (2004) observaram que, nas duas primeiras semanas após o desmame, o CDR de leitões recebendo um composto à base de extratos de canela, tomilho e orégano fora semelhante ao de animais recebendo 110 ppm de lincomicina e ou de animais não recebendo aditivo (controle). Na terceira semana, no entanto, o CDR foi significativamente menor no grupo consumindo extratos herbáceos, voltando, no entanto, a não diferir dos outros grupos, na quarta semana.

Lovatto et al. (2005) compararam a adição de 0,05\% e 0,15\% na dieta de extrato de alho em pó (Allium sativum), em relação à adição de 250 ppm de sulfato de colistina ou à não adição de aditivos em leitões de 35 a 62 dias de idade. O GDP tanto do grupo controle quanto de ambos recebendo extrato de alho na dieta foram inferiores ao GDP do grupo recebendo colistina dos 53 aos 62 dias de idade; o CDR dos animais recebendo alho inferior ao do grupo recebendo colistina, de 44 a 52 dias. Em relação à CA, diferenças significativas apareceram somente de 53 a 62 dias de idade, sendo a CA dos animais recebendo $0,15 \%$ de alho na dieta significativamente pior que os outros 4 tratamentos. No entanto, as principais substâncias presentes no alho, a alicina e a garlicina (HAUPTLI et al., 2007) são diferentes daqueles presentes no fito composto avaliado no presente estudo. Deve 
ser ressaltado também que os animais começaram a receber os tratamentos duas semana após o desmame, o que pode ter concorrido para esse efeito mais tardio e de difícil comparação entre os estudos, mas o que se observa é uma ação por vezes não imediata e tardia e também na dependência da idade dos animais.

Dos 35 aos 48 dias houve também efeito da inoculação experimental, realizada aos 35 dias de idade, sobre o CDR nos leitões, de modo que o consumo na sala inoculada foi inferior à da sala que não recebeu o desafio. A queda no consumo alimentar logo após inoculação experimental por Salmonella typhimurium em leitões na fase de creche e posterior recuperação foi também observada por outros autores (BALAJI et al., 2000; TURNER et al., 2002b; JOHNSON et al., 2005). Balaji et al. (2000) notaram que a inoculação experimental em leitões de 35 dias de idade levou à queda do CDR até o quinto dia após a inoculação, retornando aos níveis similares a de animais não inoculados no sexto dia após a inoculação, possivelmente em decorrência de alterações ligadas ao estresse (houve aumento na concentração de cortisol plasmático destes animais) e inflamatórias (a temperatura retal dos leitões inoculados permaneceu maior durante todo o período experimental). Essa queda no CDR foi acompanhada, no entanto, de queda no GDP, o que não foi observado no presente estudo.

Curiosamente, o efeito de sala sobre o CDR deixou de ser significativo após os 49 dias de idade (Tabelas 11 e 12) mas voltou a ser significativo dos 96 aos 105 dias e dos 106 aos 131 dias (Tabela 12); no entanto, ao contrário do que ocorrera na creche, o CDR passou a ser maior na sala desafiada, sugerindo efeito compensatório quanto ao CDR após a inoculação, de modo que leitões desafiados passaram a consumir maior quantidade de ração ao final da fase de crescimento e na fase de terminação.

Quanto ao efeito compensatório sobre consumo, o único estudo utilizando inoculação experimental de Salmonella typhimurium encontrado na literatura que tem semelhança foi o de Turner et al. (2002b). Segundo estes autores, uma semana após a inoculação experimental, realizada aos 38 dias de idade, o GDP, CDR e eficiência alimentar dos animais inoculados foram significativamente menores aos não inoculados; no entanto, na semana seguinte, esse quadro se reverteu, de modo que CDR do grupo inoculado aumentou, sem correspondente aumento no CDR do grupo controle, que se manteve estável. Isto ocasionou uma melhora significativa no GDP e um aumento numérico na eficiência alimentar do grupo inoculado. Assim 
como no presente estudo, Turner et al. (2002b) não encontraram justificativa para essa melhora nos índices de desempenho nos animais inoculados, atribuindo a efeito de confundimento entre as salas. Não foram encontrados, no entanto, trabalhos na literatura que avaliassem o desempenho nas fases de crescimento e terminação de leitões recebendo inoculação experimental de S. typhimurium durante a fase de creche, havendo, portanto, necessidade de futuras averiguações. Uma possível causa deste crescimento compensatório em animais desafiados é uma recuperação do sistema imunológico logo após a situação de desafio ser superada, apesar dos mecanismos que levam a esse fenômenos não serem compreendidos ainda (KLASING, 1994).

Houve indicação de efeito de aditivo $(p=0,11)$ dos 96 aos 105 dias (final da fase de crescimento), sendo, numericamente, a CDR do grupo FITO $(2,67)$ inferior a do grupo CTRL $(2,82)$ e ATB $(2,86)$, conforme a tabela 12. A diminuição no CDR em decorrência da suplementação com compostos à base de ervas naturais também foi relatada por vários autores, em suínos (NAMKUNG et al., 2004; JUGL-CHIZZOLA et al., 2006), frangos de corte (ALÇIÇEK et al., 2003; ZHANG et al., 2005) e perus (BAMPIDIS et al., 2005), sendo atribuído esse efeito à alteração no sabor e odor da ração em função de alguns compostos fenólicos e glicopiranosídeos, que possuem sabor amargo, azedo, adstringentes, ou sabor específico de fenóis (LULE; XIA, 2005) e que possivelmente causam um feedback negativo pós ingestão (BAMPIDIS et al., 2005b). Na alimentação humana, as alterações nas características organolépticas causadas por extratos herbáceos restringe a utilização de alguns deles como aditivos e na preservação de alimentos (BURT, 2004). Jugl-Chizzola et al. (2006), realizando teste de consumo em leitões desmamados, observaram que a adição de quantidades diferentes de tomilho ou orégano, ou ambos, levaram à depressão do consumo alimentar em relação à não adição de aditivos, exceto a adição de $0,1 \%$ de tomilho.

Oetting et al. (2005) utilizou a tecnologia de microencapsulamento de extratos vegetais para amenizar essa adversidade, e não observou queda de consumo de leitões recebendo extratos vegetais em relação a animais que não receberam aditivos de 1 até 14 dias após o desmame, o mesmo sendo observado de 1 a 35 dias pós desmame. Costa et al. (2006), no entanto, encontraram valores ligeiramente inferiores de CDR de 1 a 14 dias após o desmame em leitões recebendo extratos de orégano $(210$ ppm de óleo essencial de orégano +210 ppm 
de carvacrol), em relação a leitões que não receberam aditivos na ração, mesmo sendo esses extratos microencapsulados.

Outros autores, ao contrário, observaram maior consumo alimentar de animais recebendo produtos à base de ervas naturais. Guo et al. (2004), administrando um composto de 14 ervas chinesas secas e trituradas para frangos de corte, observaram maior consumo alimentar dos 21 aos 28 dias de idade das aves em relação à animais que não foram suplementados ou que receberam 20 ppm de virgiamicna. Este aumento no consumo fora acompanhado de uma menor conversão alimentar. Allan e Bilkei (2005) acompanharam 3610 porcas de um rebanho húngaro entre 1998 e 2003, e observaram que a suplementação da dieta de lactação com 1000 ppm de orégano ocasionou maior consumo alimentar em porcas multíparas em relação a animais não suplementados, embora tal efeito não fosse observado nas fêmeas primíparas. 
Tabela 11 - Valores médios e desvios padrão da variável consumo diário de ração (CDR), em quilogramas/animal/dia, de leitões dos 21 aos 34, 35 aos 48, 49 aos 63 e 21 aos 63 dias de idade, recebendo na dieta fito composto (FITO), antibiótico (ATB) ou sem aditivo algum na dieta (CTRL), nas salas desafiadas (D) ou não desafiadas (SD)

\begin{tabular}{|c|c|c|c|c|c|c|c|c|}
\hline \multirow[b]{2}{*}{ Período } & \multirow[b]{2}{*}{ Sala } & \multicolumn{3}{|c|}{ Aditivos } & \multirow[b]{2}{*}{ Médias $^{2}$} & \multicolumn{3}{|c|}{$\mathbf{P}$} \\
\hline & & FITO & CTRL & ATB & & aditivo & sala & aditivo*sala \\
\hline 21 a 34 & $\mathrm{D}$ & $0,30 \pm 0,04$ & $0,29 \pm 0,03$ & $0,36 \pm 0,05$ & $0,32 \pm 0,05$ & 0,0004 & ns & ns \\
\hline dias & SD & $0,28 \pm 0,06$ & $0,29 \pm 0,02$ & $0,39 \pm 0,04$ & $0,32 \pm 0,06$ & & & \\
\hline 35 a 48 & $\mathrm{D}$ & $0,51 \pm 0,08$ & $0,52 \pm 0,10$ & $0,64 \pm 0,09$ & $0,56 \pm 0,10^{B}$ & 0,002 & 0,02 & ns \\
\hline dias & SD & $0,56 \pm 0,09$ & $0,60 \pm 0,10$ & $0,77 \pm 0,10$ & $0,64 \pm 0,13^{A}$ & & & \\
\hline Médias $^{1}$ & & $0,54 \pm 0,08^{b}$ & $0,56 \pm 0,10^{b}$ & $0,70 \pm 0,11^{a}$ & & & & \\
\hline Médias $^{1}$ & & $1,17 \pm 0,14$ & $1,23 \pm 0,12$ & $1,33 \pm 0,16$ & & & & \\
\hline 21 a 63 & $D$ & $0,67 \pm 0,03$ & $0,68 \pm 0,08$ & $0,78 \pm 0,09$ & $0,71 \pm 0,08$ & 0,007 & ns & ns \\
\hline dias & SD & $0,66 \pm 0,11$ & $0,70 \pm 0,08$ & $0,83 \pm 0,11$ & $0,73 \pm 0,12$ & & & \\
\hline Médias $^{1}$ & & $0,66 \pm 0,07^{b}$ & $0,69 \pm 0,08^{b}$ & $0,80 \pm 0,10^{a}$ & & & & \\
\hline
\end{tabular}

Médias seguidas de letras minúsculas diferentes na mesma linha ou de letras maiúsculas na mesma coluna diferem entre si pelo teste de Tukey $(P<0,05)$.

Média ${ }^{1}$ : médias obtidas pelos diferentes aditivos

Média ${ }^{2}$ : médias obtidas em cada sala

P: probabilidades.

Ns: não significativo 
Tabela 12 - Valores médios e desvios padrão da variável consumo diário de ração (CDR), em quilogramas/animal/dia, de leitões dos 63 aos 95, 96 aos 105, 106 aos 131 e 63 aos 131 dias de idade, recebendo na dieta fito composto (FITO), antibiótico (ATB) ou sem aditivo algum na dieta (CTRL), nas salas desafiadas (D) ou não desafiadas (SD)

\begin{tabular}{|c|c|c|c|c|c|c|c|c|}
\hline \multirow[b]{2}{*}{ Período } & \multirow[b]{2}{*}{ Sala } & \multicolumn{3}{|c|}{ Aditivos } & \multirow[b]{2}{*}{ Médias $^{2}$} & \multicolumn{3}{|c|}{$\mathbf{P}$} \\
\hline & & FITO & CTRL & ATB & & aditivo & sala & aditivo*sala \\
\hline 63 a 95 & $\mathrm{D}$ & $2,08 \pm 0,26$ & $2,01 \pm 0,12$ & $2,02 \pm 0,28$ & $2,04 \pm 0,21$ & ns & ns & ns \\
\hline dias & SD & $1,86 \pm 0,12$ & $1,94 \pm 0,18$ & $1,98 \pm 0,18$ & $1,92 \pm 0,16$ & & & \\
\hline Médias $^{1}$ & & $1,97 \pm 0,22$ & $1,97 \pm 0,15$ & $2,00 \pm 0,22$ & & & & \\
\hline 96 a 105 & $\mathrm{D}$ & $2,78 \pm 0,06$ & $2,87 \pm 0,15$ & $2,94 \pm 0,25$ & $2,87 \pm 0,17^{A}$ & 0,11 & 0,04 & ns \\
\hline dias & SD & $2,58 \pm 0,18$ & $2,76 \pm 0,14$ & $2,79 \pm 0,24$ & $2,71 \pm 0,20^{B}$ & & & \\
\hline Médias $^{1}$ & & $2,67 \pm 0,16$ & $2,82 \pm 0,15$ & $2,86 \pm 0,24$ & & & & \\
\hline 106 a 131 & $\mathrm{D}$ & $3,23 \pm 0,28$ & $3,13 \pm 0,14$ & $3,19 \pm 0,16$ & $3,19 \pm 0,19^{A}$ & ns & 0,05 & ns \\
\hline dias & SD & $2,89 \pm 0,31$ & $3,09 \pm 0,23$ & $3,04 \pm 0,24$ & $3,01 \pm 0,26^{B}$ & & & \\
\hline Médias $^{1}$ & & $3,06 \pm 0,33$ & $3,11 \pm 0,18$ & $3,12 \pm 0,21$ & & & & \\
\hline 63 a 131 & $\mathrm{D}$ & $2,52 \pm 0,17$ & $2,51 \pm 0,07$ & $2,59 \pm 0,14$ & $2,54 \pm 0,12^{A}$ & ns & 0,02 & ns \\
\hline dias & SD & $2,34 \pm 0,08$ & $2,47 \pm 0,11$ & $2,49 \pm 0,14$ & $2,43 \pm 0,12^{B}$ & & & \\
\hline Médias $^{1}$ & & $2,42 \pm 0,15$ & $2,49 \pm 0,09$ & $2,54 \pm 0,14$ & & & & \\
\hline
\end{tabular}

Médias seguidas de letras minúsculas diferentes na mesma linha ou de letras maiúsculas na mesma coluna diferem entre si pelo teste de Tukey $(P<0,05)$. Média ${ }^{1}$ : médias obtidas pelos diferentes aditivos

Média ${ }^{2}$ : médias obtidas em cada sala

P: probabilidades.

Ns: não significativo 


\subsubsection{Conversão alimentar (CA)}

As tabelas 13 e 14 apresentam, respectivamente, os valores médios e desvios-padrão das características relacionadas à conversão alimentar (CA) dos 21 aos 34, 35 aos 48 e 49 aos 63 dias de idade (Tabela 13) e dos 63 aos 95, 96 aos 105 e 106 aos 131 dias de idade (Tabela 14).

De 21 a 34 dias de idade, a CA do grupo FITO manteve-se intermediária à CA dos grupos ATB e CTRL, não diferindo estatisticamente de ambas, enquanto a CA do grupo ATB foi estatisticamente inferior à do grupo CTRL (Tabela 13). Após a primeira quinzena, deixou de haver efeito dos aditivos sobre a CA. Portanto, durante a primeira quinzena de creche, FITO promoveu uma melhor CA quando comparado com a não adição de promotores na ração (CTRL). Maass et al. (2005) também observaram melhora na conversão alimentar de leitões suplementados com partes aéreas secas e trituradas de uma planta medicinal (Echinacea purpurea) durante as duas primeiras semanas da creche, sem correspondente melhora no GDP ou CDR. Neste período, animais recebendo $1,8 \%$ da planta na dieta apresentaram menor CA $(1,54)$ do que aqueles recebendo 20 ppm de flavomicina $(1,56)$ ou dos que não foram suplementados com promotor algum na dieta $(1,60)$. Ao suplementar leitões em fase de crescimento e terminação com essa mesma planta, esses autores observaram conversão alimentar significativamente menor no grupo recebendo $0,15 \%$ da planta $(2,45)$ do que em animais que não foram suplementados $(2,51)$. Os autores concluíram que essa melhora foi devido às propriedades imunoestimulantes da planta, avaliada através do maior título de anticorpos em resposta à vacina contra erisipela do grupo recebendo E. purpurea. Oetting (2005) também observou melhor conversão alimentar em leitões na fase de creche recebendo extratos vegetais que naqueles recebendo antibiótico ou não recebendo aditivos na dieta, após 35 dias de suplementação, apesar dessa diferença não ser estatisticamente significativa.

A melhora da CA em relação à não adição de aditivos (grupo CTRL) observada no presente estudo pode ser atribuída às propriedades imunomoduladoras e antibacterianas de substâncias presentes nas plantas utilizadas. Outra possível causa para essa melhora da CA no grupo FITO em 
comparação com CTRL é a propriedade que alguns dos compostos presentes nos aditivos fitogênicos de estimular a secreção enzimática do trato gastrointestinal, e essa hipótese se faz bem provável no presente estudo, pelo fato desta melhora ocorrer nas duas primeiras semanas após o desmame. O desmame nos leitões é marcado por alterações significativas do ponto de vista social, ambiental, e nutricional, que resultam em um período crítico de baixa ingestão de alimento, que ocasionam uma queda transitória na secreção de enzimas digestivas, seguido por recuperação (MARION et al., 2003). Por conseguinte, é consenso que a digestibilidade e absorção de nutrientes nos leitões tende a diminuir nessa primeira fase após o desmame. Marion et al. (2003) observaram que, as atividades específicas da tripsina e da lipase no pâncreas diminuíram durante a primeira semana após o desmame, bem como as concentrações plasmáticas de gastrina e colecistoquinina, hormônios associados à secreção de enzimas digestivas pelo pâncreas.

Por outro lado, vários autores relatam melhora na secreção de enzimas digestivas resultante da adição de compostos fitogênicos na dieta. Lee et al. observaram que a adição de óleos essenciais na dieta de frangos levou ao aumento da atividade da amilase na digesta, aumento no peso do fígado e pâncreas aos 21 dias de idade, apesar de não haver melhora sobre os parâmetros de desempenho. Segundo Hernández et al. (2004), essa melhora na atividade secretora das enzimas digestivas pode ter levado à melhora na digestibilidade fecal da matéria seca, digestibilidade aparente ileal da matéria seca e do amido (ração inicial) e na digestibilidade aparente fecal da matéria seca e proteína bruta (ração terminação), em frangos recebendo óleos essenciais. Da mesma maneira, Oetting (2005) verificou que a digestibilidade fecal da matéria seca foi maior em leitões suplementados com aditivos fitogênicos do que com antibióticos e não suplementados. O aumento na digestibilidade através do aumento na secreção de enzimas pancreáticas pode também ser potencializado pela ação colerética de algumas plantas presentes no fito composto avaliado (HOEFLER et al., 1987).

Após a primeira quinzena de creche, não houve efeito de aditivos sobre a CA. De modo geral, a não observação de efeito sobre a CA pode ser resultante da comparação entre grupos de animais que receberam ou não promotores de crescimento. Conseqüentemente, um requerimento de mantença mais elevado nos animais do grupo recebendo ATB foi compensado por um melhor desempenho. Uma 
melhor estimação da eficiência de crescimento entre grupos de animais com diferentes intensidades de crescimento é citada por Schöne et al. (2006), que recomendam estabelecer um peso final com variação na duração do crescimento.

O fato dos aditivos, já na primeira quinzena do experimento, exercerem efeito sobre as variáveis de desempenho dos animais (PM, GDP, CDR e CA) pode parecer controverso, uma vez que os animais não haviam sido desafiados experimentalmente neste período (a Salmonella typhimurium foi inoculada somente no dia 35). É conhecido que os promotores de crescimento só levam à melhora de desempenho em situações de desafio (SPINOSA et al., 2002); no entanto, algumas considerações devem ser feitas. Os leitões foram trazidos, logo após o desmame, à granja experimental na qual fora realizado o experimento, sofrendo grande estresse na viagem. Outro fator que deve ser levado em conta é a época do ano na qual fora realizado o experimento, sendo a região acometida por baixas temperaturas a alta amplitude térmica (Tabela 5), de modo que os animais, apesar das instalações de creche contar com fonte suplementar de aquecimento, sofreram nos primeiros dias o efeito do estresse térmico. No entanto, não houve diferença entre as salas desafiada e não desafiadas sobre o CDR, GDP e CA dos animais (respectivamente $p=0,92$, $0,76$ e 0,70$)$, bem como sobre o PM aos 35 dias $(p=0,82)$, nem sobre a eliminação fecal de Salmonella typhimurium $(p=0,50)$.

De 35 a 48 dias, a CA foi influenciada somente pelo desafio experimental, de modo que a CA na sala desafiada foi menor que na sala sem desafio (respectivamente, 1,07 vs 1,22). Esse efeito se deu principalmente devido à depressão sofrida no CDR na sala desafiada neste período, e repercutiu na CA do período total de creche (nota-se que, apesar de não haver efeito significativo de sala sobre a CA de 21 a 63 dias, há uma tendência à significância para menor CA na sala desafiada, com $p=0,08)$. Houve ainda efeito de sala sobre a CA de 96 a 105 dias (CA na sala desafiada foi menor que na sala não desafiada), e uma indicação de efeito dos 106 a 131 dias (CA numericamente maior na sala desafiada). 
Tabela 13 - Valores médios e desvios padrão da variável conversão alimentar (CA) de leitões dos 21 aos 34,35 aos 48,49 aos 63 e 21 aos 63 dias de idade, recebendo na dieta fito composto (FITO), antibiótico (ATB) ou sem aditivo algum na dieta (CTRL), nas salas desafiadas (D) ou não desafiadas (SD)

\begin{tabular}{|c|c|c|c|c|c|c|c|c|}
\hline \multirow[b]{2}{*}{ Período } & \multirow[b]{2}{*}{ Sala } & \multicolumn{3}{|c|}{ Aditivos } & \multirow[b]{2}{*}{ Médias $^{2}$} & \multicolumn{3}{|c|}{$\mathbf{P}$} \\
\hline & & FITO & CTRL & ATB & & aditivo & sala & aditivo*sala \\
\hline 21 a 34 & $\mathrm{D}$ & $1,57 \pm 0,14$ & $1,77 \pm 0,47$ & $1,33 \pm 0,27$ & $1,55 \pm 0,36$ & 0,02 & ns & $\mathrm{ns}$ \\
\hline dias & SD & $1,67 \pm 0,23$ & $1,74 \pm 0,39$ & $1,39 \pm 0,06$ & $1,60 \pm 0,29$ & & & \\
\hline Médias $^{1}$ & & $1,62 \pm 0,19^{a b}$ & $1,75 \pm 0,41^{a}$ & $1,35 \pm 0,19^{b}$ & & & & \\
\hline 35 a 48 & $\mathrm{D}$ & $1,05 \pm 0,20$ & $1,10 \pm 0,11$ & $1,07 \pm 0,09$ & $1,07 \pm 0,13^{B}$ & ns & 0,003 & ns \\
\hline dias & SD & $1,26 \pm 0,09$ & $1,19 \pm 0,05$ & $1,20 \pm 0,10$ & $1,22 \pm 0,08^{A}$ & & & \\
\hline Médias $^{1}$ & & $1,16 \pm 0,18$ & $1,14 \pm 0,09$ & $1,13 \pm 125$ & & & & \\
\hline 49 a 63 & $\mathrm{D}$ & $2,05 \pm 0,24$ & $2,01 \pm 0,15$ & $2,04 \pm 0,15$ & $2,03 \pm 0,17$ & ns & ns & ns \\
\hline dias & SD & $1,99 \pm 0,19$ & $2,04 \pm 0,16$ & $2,21 \pm 0,33$ & $2,08 \pm 0,24$ & & & \\
\hline Médias $^{1}$ & & $2,02 \pm 0,21$ & $2,03 \pm 0,15$ & $2,12 \pm 0,26$ & & & & \\
\hline 21 a 63 & $\mathrm{D}$ & $1,61 \pm 0,11$ & $1,62 \pm 0,09$ & $1,52 \pm 0,07$ & $1,58 \pm 0,10$ & ns & 0,08 & ns \\
\hline dias & SD & $1,66 \pm 0,06$ & $1,65 \pm 0,05$ & $1,62 \pm 0,12$ & $1,64 \pm 0,08$ & & & \\
\hline Médias $^{1}$ & & $1,63 \pm 0,09$ & $1,64 \pm 0,07$ & $1,57 \pm 0,10$ & & & & \\
\hline
\end{tabular}

Médias seguidas de letras minúsculas diferentes na mesma linha ou de letras maiúsculas na mesma coluna diferem entre si pelo teste de Tukey $(P<0,05)$,

Média ${ }^{1}$ : médias obtidas pelos diferentes aditivos

Média $^{2}$ : médias obtidas em cada sala

P: probabilidades.

Ns: não significativo 
Tabela 14 - Valores médios e desvios padrão da variável conversão alimentar (CA) de leitões dos 63 aos 95,96 aos 105,106 aos 131 e 63 aos 131 dias de idade, recebendo na dieta fito composto (FITO), antibiótico (ATB) ou sem aditivo algum na dieta (CTRL), nas salas desafiadas (D) ou não desafiadas (SD)

\begin{tabular}{|c|c|c|c|c|c|c|c|c|}
\hline \multirow[b]{2}{*}{ Período } & \multirow[b]{2}{*}{ Sala } & \multicolumn{3}{|c|}{ Aditivos } & \multirow[b]{2}{*}{ Médias $^{2}$} & \multicolumn{3}{|c|}{$\mathbf{P}$} \\
\hline & & FITO & CTRL & ATB & & aditivo & sala & aditivo*sala \\
\hline 63 a 95 & $\mathrm{D}$ & $2,25 \pm 0,27$ & $2,12 \pm 0,12$ & $2,28 \pm 0,25$ & $2,21 \pm 0,22$ & ns & ns & $\mathrm{ns}$ \\
\hline dias & SD & $2,17 \pm 0,12$ & $2,09 \pm 0,11$ & $2,19 \pm 0,18$ & $2,15 \pm 0,14$ & & & \\
\hline Médias $^{1}$ & & $2,21 \pm 0,20$ & $2,11 \pm 0,11$ & $2,23 \pm 0,21$ & & & & \\
\hline 96 a 105 & $\mathrm{D}$ & $2,22 \pm 0,23$ & $2,38 \pm 0,33$ & $2,40 \pm 0,36$ & $2,33 \pm 0,30^{B}$ & 0,12 & 0,02 & ns \\
\hline dias & SD & $2,54 \pm 0,37$ & $3,00 \pm 0,49$ & $2,44 \pm 0,19$ & $2,67 \pm 0,43^{A}$ & & & \\
\hline Médias $^{1}$ & & $2,36 \pm 0,33$ & $2,69 \pm 0,51$ & $2,42 \pm 0,27$ & & & & \\
\hline 106 a 131 & $\mathrm{D}$ & $3,34 \pm 0,28$ & $3,01 \pm 0,22$ & $3,36 \pm 0,46$ & $3,23 \pm 0,34$ & ns & 0,10 & ns \\
\hline dias & SD & $2,83 \pm 0,78$ & $2,99 \pm 0,62$ & $2,94 \pm 0,38$ & $2,92 \pm 0,57$ & & & \\
\hline Médias $^{1}$ & & $3,08 \pm 0,61$ & $3,00 \pm 0,43$ & $3,13 \pm 0,45$ & & & & \\
\hline 63 a 131 & $\mathrm{D}$ & $2,55 \pm 0,14$ & $2,50 \pm 0,10$ & $2,67 \pm 0,17$ & $2,56 \pm 0,15$ & ns & ns & ns \\
\hline dias & SD & $2,57 \pm 0,31$ & $2,67 \pm 0,15$ & $2,52 \pm 0,12$ & $2,59 \pm 0,20$ & & & \\
\hline Médias $^{1}$ & & $2,56 \pm 0,23$ & $2,59 \pm 0,15$ & $2,59 \pm 0,16$ & & & & \\
\hline
\end{tabular}

Médias seguidas de letras minúsculas diferentes na mesma linha ou de letras maiúsculas na mesma coluna diferem entre si pelo teste de Tukey (P<0,05). Média ${ }^{1}$ : médias obtidas pelos diferentes aditivos

Média ${ }^{2}$ : médias obtidas em cada sala

P: probabilidades.

Ns: não significativo 


\subsubsection{Desempenho durante o período final de crescimento (96 aos 105 dias de idade)}

A tabela 15 mostra os valores médios e desvios padrão das características relacionadas ao ganho diário de peso (GDP), consumo diário de ração (CDR) e conversão alimentar (CA) no período final da fase de crescimento (96 aos 105 dias de idade). Uma análise atenta deste período revela algumas informações interessantes.

Durante esse período, o GDP, CDR e CA foram influenciados significativamente pelo efeito de sala (as duas primeiras variáveis revelaram valores maiores na sala desafiada, enquanto a CA foi menor nesta sala). O PM aos 105 dias foi também significativamente superior na sala desafiada. Portanto, leitões que receberam o desafio experimental durante a creche apresentaram melhor desempenho de 96 a 105 dias de idade. Possíveis causas desse melhor desempenho já foram discutidas no item 5.2.3.

Uma análise aprofundada dos valores numéricos de desempenho dos tratamentos FITO e ATB, na sala desafiada, no período de 96 a 105 dias, revela alguns dados interessantes: o CDR dos leitões consumindo ATB foi numericamente superior ao do grupo FITO (respectivamente 2,94 vs 2,78 kg/animal/dia). Não obstante o menor consumo de FITO na sala desafiada, este grupo apresentou maior ganho de peso que ATB (respectivamente, 1,32 vs 1,24 kg/animal/dia). Essa diferença veio interferir na CA (CA de FITO e ATB na sala desafiada foram, respectivamente, iguais a 2,22 e 2,40). Assim, não há a igual manutenção do desempenho tanto de ATB quanto do CTRL em uma situação de desafio (como pode ser observado na tabela 15, os valores de CDR, GDP e CA do grupo CTRL na sala desafiada, no período final da fase de crescimento, se aproximam mais dos valores do grupo ATB que FITO). Portanto, na fase final de crescimento, houve uma melhora, embora numérica, de desempenho dos animais do grupo FITO em relação à CTRL e ATB, na sala desafiada, que pode ser atribuída a um ganho compensatório destes animais. Uma possível explicação para esse achado é o fato das plantas medicinais apresentarem ação hepatoprotetora (HOEFLER et al., 1987; AL-SEREITI et al., 1999) e detoxificadora (DEBERSAC et al., 2001), de modo que o fígado dos leitões desafiados durante a creche e recebendo FITO possuía maior 
capacidade para depurar toxinas bacterianas presentes no organismo animal em uma fase posterior. Outro aspecto inerente às ervas medicinais que pode ter concorrido para esse melhor desempenho do grupo FITO sob uma situação de desafio é a capacidade que alguns desses compostos possuírem atuação seletiva sobre bactérias potencialmente patogênicas, enquanto que agentes antimicrobianos agem indiscriminadamente tanto sobre bactérias patogênicas quanto benéficas (NAKUMNG et al., 2004; SI et al., 2006). Assim, em uma fase inicial, o fito composto pode ter causado eliminação de menor número de bactérias benéficas que os antimicrobianos utilizados, promovendo uma maior saúde do ponto de vista entérico em fases posteriores.

O fato dessa recuperação ter ocorrido nessa fase é um dado relevante, uma vez que o final do período de crescimento é uma fase na qual os animais estão em intensa deposição de tecido muscular, e a presença de um ganho de peso compensatório repercutirá na qualidade de carcaça ao abate. De fato, outros autores encontraram evidências de que o uso de compostos de ervas naturais como promotores de crescimento, durante o período de crescimento e terminação, pode levar à melhoras na qualidade da carcaça, em comparação à adição de antimicrobianos. Lima et al. (2001) observaram que um composto à base de Hyperium perforatum, Allium sativum, Origanum majorana, Mentha piperita, Rosmarinus officinalis, Thymus vulgaris, Juniperus communis e Allium cepa, administrado a leitões dos 64 aos 148 dias de idade, levou a aumento na profundidade de lombo e porcentagem de carne na carcaça quente, em relação à administração de 25 ppm do antibiótico ionóforo salinomicina. Traçando-se um paralelo com o presente estudo, observamos que algumas das plantas utilizadas por esses autores estão no composto avaliado, apesar do antibiótico e de sua dosagem diferir daqueles utilizados. Nesse estudo, as variáveis de desempenho (peso médio aos 148 dias, GDP, CRD e CA) não diferiram entre animais recebendo o composto de ervas naturais e antibióticos, sendo, no entanto, piores para leitões que não receberam aditivos à dieta. No entanto, essas variáveis de desempenho foram analisadas durante todo o período de crescimento e terminação, e não em subperíodos, como foi feito presentemente, o que pode ter causado a não detecção de alterações em fases distintas.

À semelhança do presente estudo, a queda no consumo alimentar com concomitante aumento na eficiência alimentar em dietas suplementadas com 
substâncias à base de ervas foi também relatada em outras espécies, tais quais perus (BAMPIDIS et al., 2005) e frangos de corte (ALÇIÇEK et al., 2003; ZHANG et al., 2005). Ainda, alguns autores observaram, concomitantemente ao aumento da eficiência alimentar, melhora no rendimento de carcaça de frangos de corte (ALÇIÇEK et al., 2003; ALÇIÇEK et al., 2004), menor porcentagem de gordura abdominal em codornas (DENLI et al., 2004) em decorrência da adição de óleos essenciais à dieta, o que corrobora a hipótese de que produtos à base de ervas naturais podem contribuir para melhoras na qualidade de carcaça e eficiência alimentar. 
Tabela 15 - Valores médios e desvios padrão das variáveis ganho diário de peso (GDP, em quilogramas/animal/dia), consumo diário de ração (CDR, em quilogramas/animal/dia) e conversão alimentar (CA) de leitões ao final do período de crescimento (96 aos 105), recebendo na dieta fito composto (FITO), antibiótico (ATB) ou sem aditivo algum na dieta (CTRL), nas salas desafiadas (D) ou não desafiadas (SD)

\begin{tabular}{|c|c|c|c|c|c|c|c|c|}
\hline \multirow[b]{2}{*}{ Variáveis } & \multirow[b]{2}{*}{ Sala } & \multicolumn{3}{|c|}{ Aditivos } & \multirow[b]{2}{*}{ Médias $^{2}$} & \multicolumn{3}{|c|}{$\mathbf{P}$} \\
\hline & & FITO & CTRL & ATB & & aditivo & sala & aditivo*sala \\
\hline GDP 96- & $\mathrm{D}$ & $1,32 \pm 0,16$ & $1,22 \pm 0,15$ & $1,24 \pm 0,14$ & $1,26 \pm 0,15^{A}$ & ns & 0,0002 & $\mathrm{~ns}$ \\
\hline 105 dias & SD & $0,94 \pm 0,20$ & $0,93 \pm 0,14$ & $1,14 \pm 0,10$ & $1,01 \pm 0,17^{B}$ & & & \\
\hline Médias $^{1}$ & & $1,13 \pm 0,26$ & $1,07 \pm 0,20$ & $1,19 \pm 0,13$ & & & & \\
\hline CDR 96- & $\mathrm{D}$ & $2,78 \pm 0,06$ & $2,87 \pm 0,15$ & $2,94 \pm 0,25$ & $2,87 \pm 0,17^{A}$ & 0,11 & 0,04 & $\mathrm{~ns}$ \\
\hline 105 dias & SD & $2,58 \pm 0,18$ & $2,76 \pm 0,14$ & $2,79 \pm 0,24$ & $2,71 \pm 0,20^{B}$ & & & \\
\hline Médias $^{1}$ & & $2,67 \pm 0,16$ & $2,82 \pm 0,15$ & $2,86 \pm 0,24$ & & & & \\
\hline CA 96- & $\mathrm{D}$ & $2,22 \pm 0,23$ & $2,38 \pm 0,33$ & $2,40 \pm 0,36$ & $2,33 \pm 0,30^{B}$ & 0,12 & 0,02 & $\mathrm{~ns}$ \\
\hline 105 dias & SD & $2,54 \pm 0,37$ & $3,00 \pm 0,49$ & $2,44 \pm 0,19$ & $2,67 \pm 0,43^{A}$ & & & \\
\hline Médias $^{1}$ & & $2,36 \pm 0,33$ & $2,69 \pm 0,51$ & $2,42 \pm 0,27$ & & & & \\
\hline
\end{tabular}

Médias seguidas de letras minúsculas diferentes na mesma linha ou de letras maiúsculas na mesma coluna diferem entre si pelo teste de Tukey $(P<0,05)$.

Média": médias obtidas pelos diferentes aditivos

Média ${ }^{2}$ : médias obtidas em cada sala

$\mathrm{P}$ : probabilidades.

Ns: não significativo 


\subsection{EVOLUÇÃO DA FREQÜÊNCIA DE DIAS COM DIARRÉIA NA CRECHE}

\subsubsection{Freqüência de dias com diarréia (FDD)}

A tabela 16 apresenta os valores médios das características relacionadas à freqüência de dias com diarréia (FDD) dos 21 aos 34, 35 aos 48 e 49 aos 63 dias de idade. Na primeira quinzena do experimento (de 21 a 34 dias de idade), houve influência de aditivo (a freqüência de dias com diarréia no grupo recebendo ATB foi estatisticamente menor que nos grupos recebendo FITO e CTRL, conforme a figura 8), assim como de sala (a sala na qual fora feito o desafio com salmonela apresentou uma FDD maior de diarréia que a sala que não foi desafiada, $p=0,035$ conforme a Figura 7), resultado conflitante, uma vez que a inoculação experimental ocorrera após decorrida essa primeira quinzena, aos 35 dias de idade.

$\mathrm{Na}$ segunda quinzena do experimento (35 a 48 dias de idade), não houve efeito de sala, havendo somente efeito de aditivo. Novamente, o tratamento ATB foi o que apresentou menor FDD (29,3\% dos dias). No entanto, o tratamento FITO apresentou melhora em relação ao CTRL, de modo que este apresentou maior FDD em relação ao primeiro (respectivamente, 81,4 vs $97,8 \%$ dos dias), conforme pode ser visto na figura 8. Resultado semelhante foi obtido por Oetting (2005). Dos 21 aos 56 dias de idade, o autor observou que a freqüência de dias com diarréia foi significativamente menor para leitões recebendo antimicrobianos $(50 \mathrm{ppm}$ de bacitracina de zinco, $50 \mathrm{ppm}$ de olanquidox e $50 \mathrm{ppm}$ de colistina) que animais recebendo extratos vegetais (cravo+eugenol, orégano+ carvacrol e tomilho) ou que não receberam aditivos na ração. No entanto, numericamente, a freqüência de dias com diarréia foi menor para animais recebendo os extratos vegetais do que para aqueles que não receberam suplementos na ração.

$\mathrm{Na}$ terceira quinzena do experimento (dos 49 aos 63 dias de idade), não houve diferenças significativas quanto à FDD em nenhum dos aditivos, nem entre as salas. Em relação a todo o período de creche (dos 21 aos 63 dias de idade), a FDD foi influenciada somente pelos aditivos, sendo esse valor estatisticamente menor em leitões recebendo ATB que nos animais recebendo FITO e CTRL, não diferindo entre si estes últimos. 
Tabela 16 - Valores médios e coeficiente de variação da freqüência de dias com diarréia (FDD) de leitões dos 21 aos 34,35 aos 48, 49 aos 63 e 21 aos 63 dias de idade, recebendo na dieta fito composto (FITO), antibiótico (ATB) ou sem aditivo algum na dieta (CTRL), nas salas desafiadas (D) ou não desafiadas (SD)

\begin{tabular}{|c|c|c|c|c|c|c|c|c|}
\hline \multirow[b]{2}{*}{ Período } & \multirow[b]{2}{*}{ Sala } & \multicolumn{3}{|c|}{ Aditivos } & \multirow[b]{2}{*}{ Médias $^{2}$} & \multicolumn{3}{|c|}{$\mathbf{P}$} \\
\hline & & FITO & CTRL & ATB & & aditivo & sala & aditivo*sala \\
\hline \multirow[t]{2}{*}{21 a 34 dias } & $\mathrm{D}$ & 97,1 & 98,6 & 75,7 & $90,5^{A}$ & 0,002 & 0,035 & $\mathrm{~ns}$ \\
\hline & SD & 90,0 & 90,0 & 52,8 & $77,6^{\text {B }}$ & & & \\
\hline Médias $^{1}$ & & $93,6^{a}$ & $94,3^{a}$ & $64,3^{b}$ & & & & \\
\hline $\mathrm{CV}$ & & 9,8 & 9,9 & 45,9 & & & & \\
\hline \multirow[t]{2}{*}{35 a 48 dias } & $D$ & 81,4 & 95,7 & 34,3 & 70,5 & $<, 0001$ & ns & ns \\
\hline & SD & 81,4 & 100,0 & 24,3 & 68,5 & & & \\
\hline Médias $^{1}$ & & $81,4^{b}$ & $97,8^{a}$ & $29,3^{c}$ & & & & \\
\hline CV & & 25,5 & 6,9 & 55,6 & & & & \\
\hline \multirow[t]{2}{*}{49 a 63 dias } & $D$ & 72,8 & 61,4 & 62,8 & 65,7 & ns & ns & ns \\
\hline & SD & 48,5 & 65,7 & 52,8 & 55,7 & & & \\
\hline Médias ${ }^{1}$ & & 60,7 & 63,5 & 57,8 & & & & \\
\hline CV & & 60,0 & 27,2 & 59,1 & & & & \\
\hline \multirow[t]{2}{*}{21 a 63 dias } & $D$ & 83,8 & 85,2 & 57,6 & 75,5 & 0,001 & ns & ns \\
\hline & SD & 73,3 & 85,2 & 43,3 & 67,3 & & & \\
\hline Médias $^{1}$ & & $78,6^{a}$ & $85,2^{a}$ & $50,5^{b}$ & & & & \\
\hline CV & & 24,8 & 7,4 & 39,0 & & & & \\
\hline
\end{tabular}

Médias seguidas de letras minúsculas diferentes na mesma linha ou de letras maiúsculas na mesma coluna diferem entre si pelo teste de Tukey ( $\mathrm{P}<0,05)$.

Média ${ }^{1}$ : médias obtidas pelos diferentes aditivos.

Média ${ }^{2}$ : médias obtidas em cada sala.

P: probabilidades.

Ns: não significativo

CV (\%): Coeficiente de Variação. 


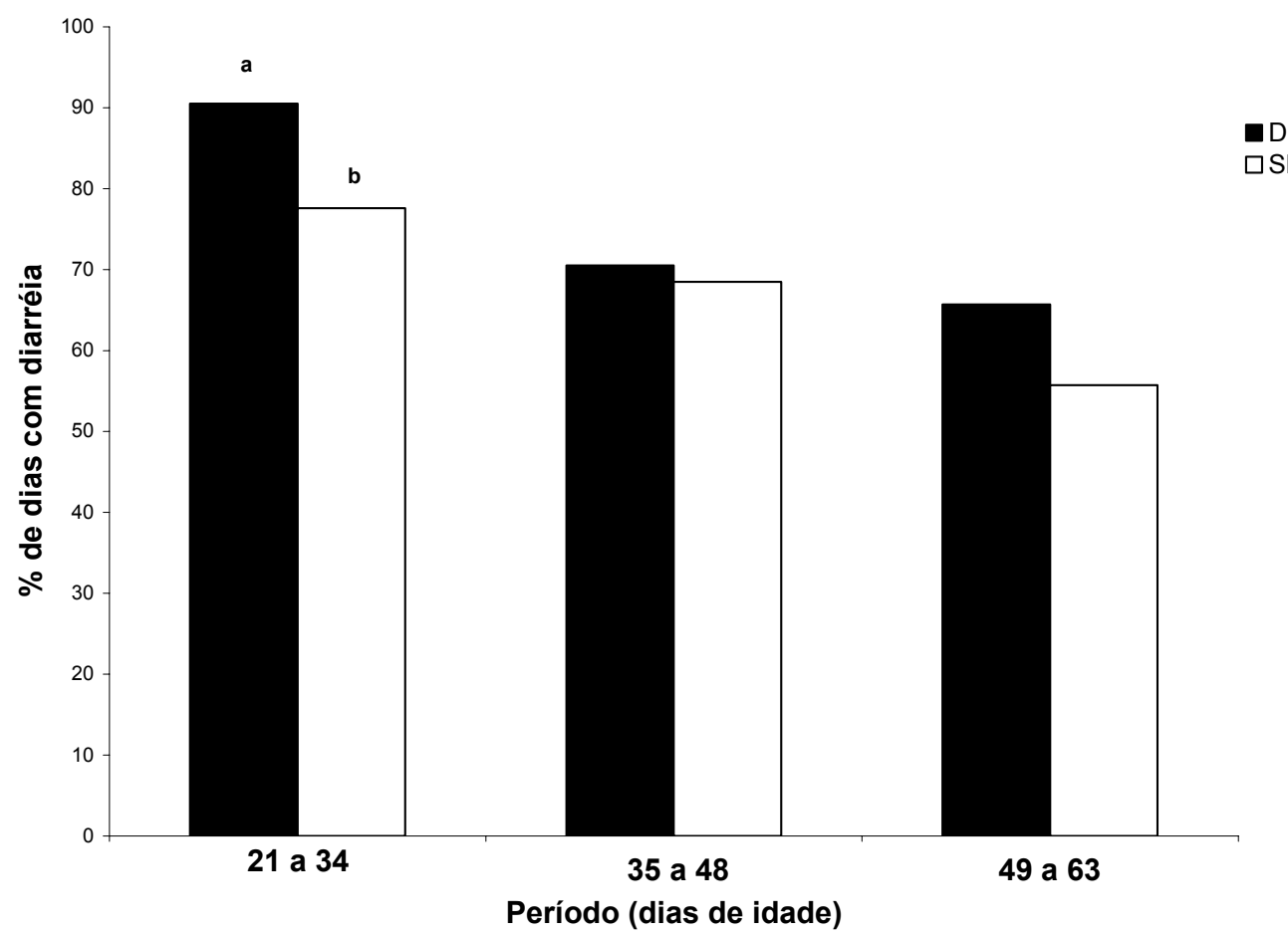

Figura 7 - Freqüência de dias com diarréia nos leitões nas salas desafiadas (D) e sem desafio (SD), dos 21 aos 34, 35 aos 48 e dos 49 aos 63 dias de idade. Médias em cada período com letras diferentes diferem estatisticamente no teste de Tukey ( $5 \%$ de significância) 


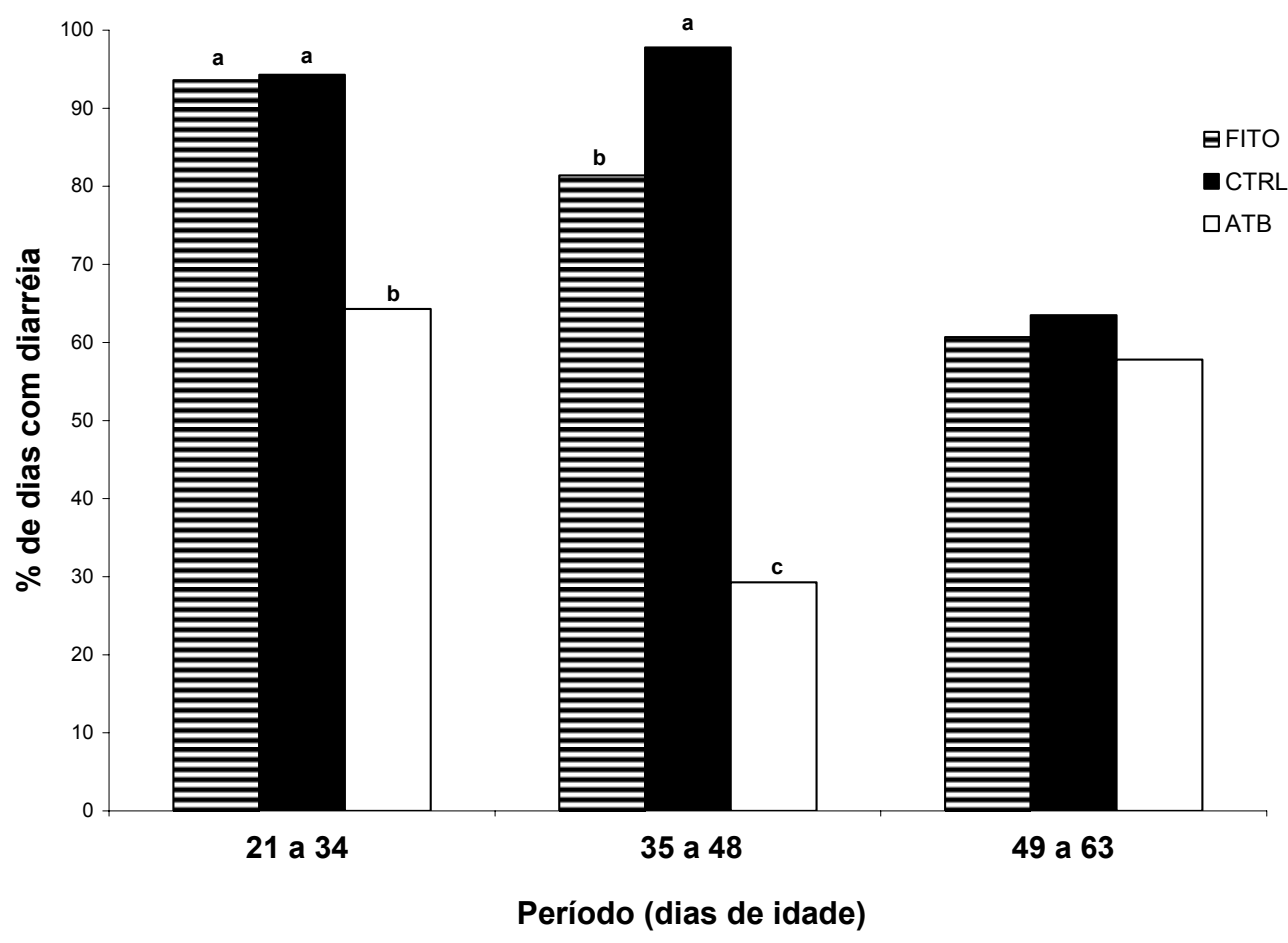

Figura 8 - Freqüência de dias com diarréia em leitões recebendo na ração fito composto (FITO), antibiótico (ATB) ou sem aditivos (CTRL) dos 21 aos 34 , 35 aos 48 e dos 49 aos 63 dias de idade. Médias em cada período com letras diferentes diferem estatisticamente no teste de Tukey $(5 \%$ de significância)

\subsubsection{Freqüência de dias com diarréia pastosa (FDDp)}

A tabela 17 apresenta os valores médios das características relacionadas à freqüência de dias com diarréia pastosa (FDDp) dos 21 aos 34,35 aos 48 e 49 aos 63 dias de idade. Durante essas três quinzenas, houve efeito de sala sobre a FDDp, sendo este valor significativamente maior na sala que não fora desafiada, nos três períodos (Figura 9).

Não houve influência dos aditivos de 21 a 34 dias sobre a FDDp. De 35 a 48 dias pode-se observar interação entre o fator sala e aditivo $(p=0,025)$, conforme explicitado na tabela 17. Na sala que não fora desafiada, a FDDp foi significativamente menor no grupo ATB $(24,3 \%)$ em relação ao grupo CTRL $(94,3 \%)$. O grupo FITO apresentou um valor intermediário $(67,1 \%)$, significativamente menor que CTRL, mas maior que ATB. Na sala desafiada, no entanto, o que se observa é 
FITO apresentando um valor de FDD p numericamente menor que CTRL e maior que ATB, mas não diferindo estatisticamente de ambos, enquanto que FDDp no grupo CTRL foi significativamente maior que no grupo ATB. No entanto, independentemente do efeito de interação e de sala, FDDp foi maior para o grupo CTRL que para FITO, conforme mostrado na tabela 17 e na figura 10 . Ao se considerar o período total de creche (21 aos 63 dias de idade), verifica-se pela tabela 17 que não houve efeito de sala, aditivo ou interação.

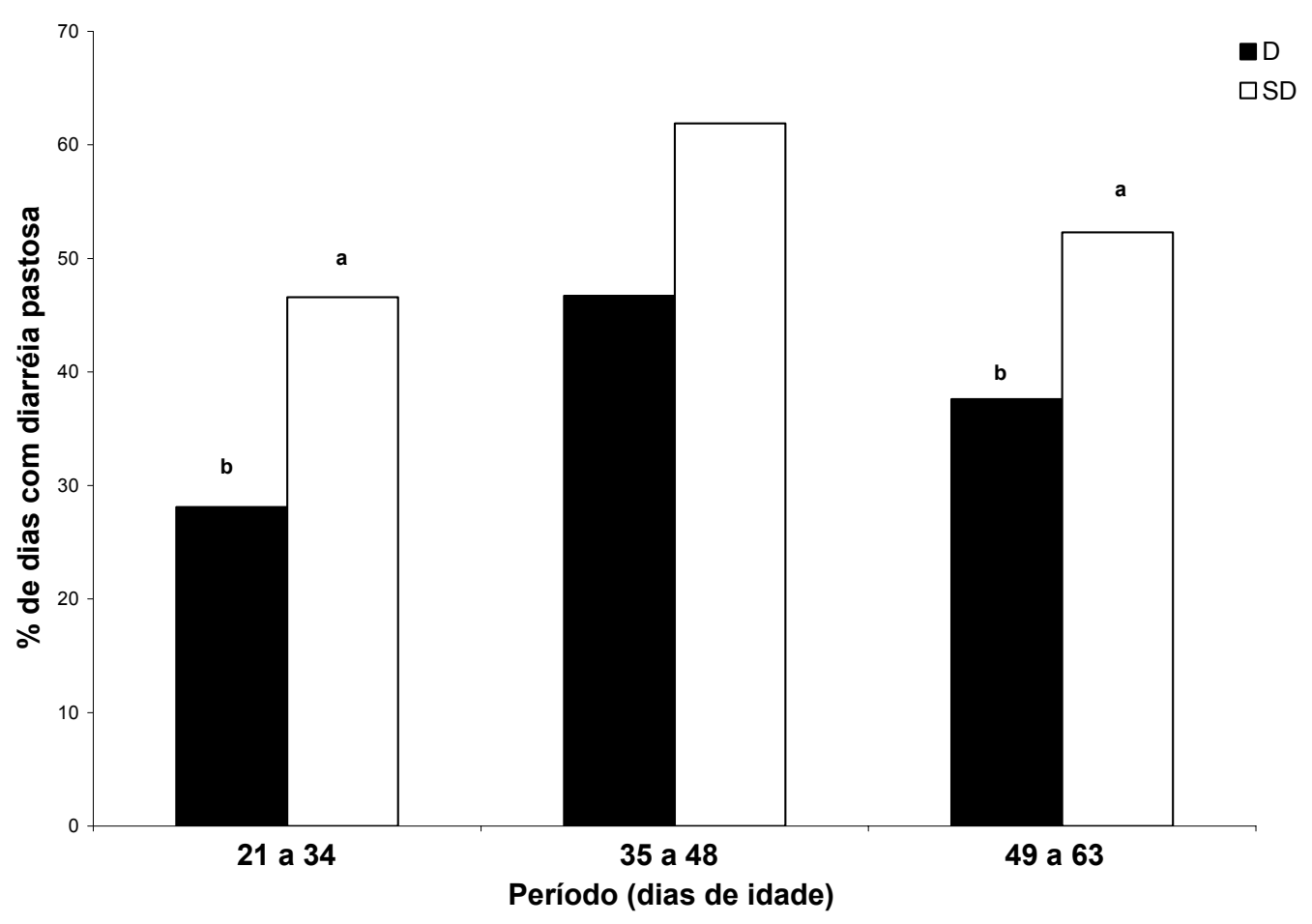

Figura 9 - Freqüência de dias com diarréia pastosa nos leitões nas salas desafiadas (D) e sem desafio (SD), dos 21 aos 34, 35 aos 48 e dos 49 aos 63 dias de idade. Médias em cada período com letras diferentes diferem estatisticamente no teste de Tukey ( $5 \%$ de significância) 


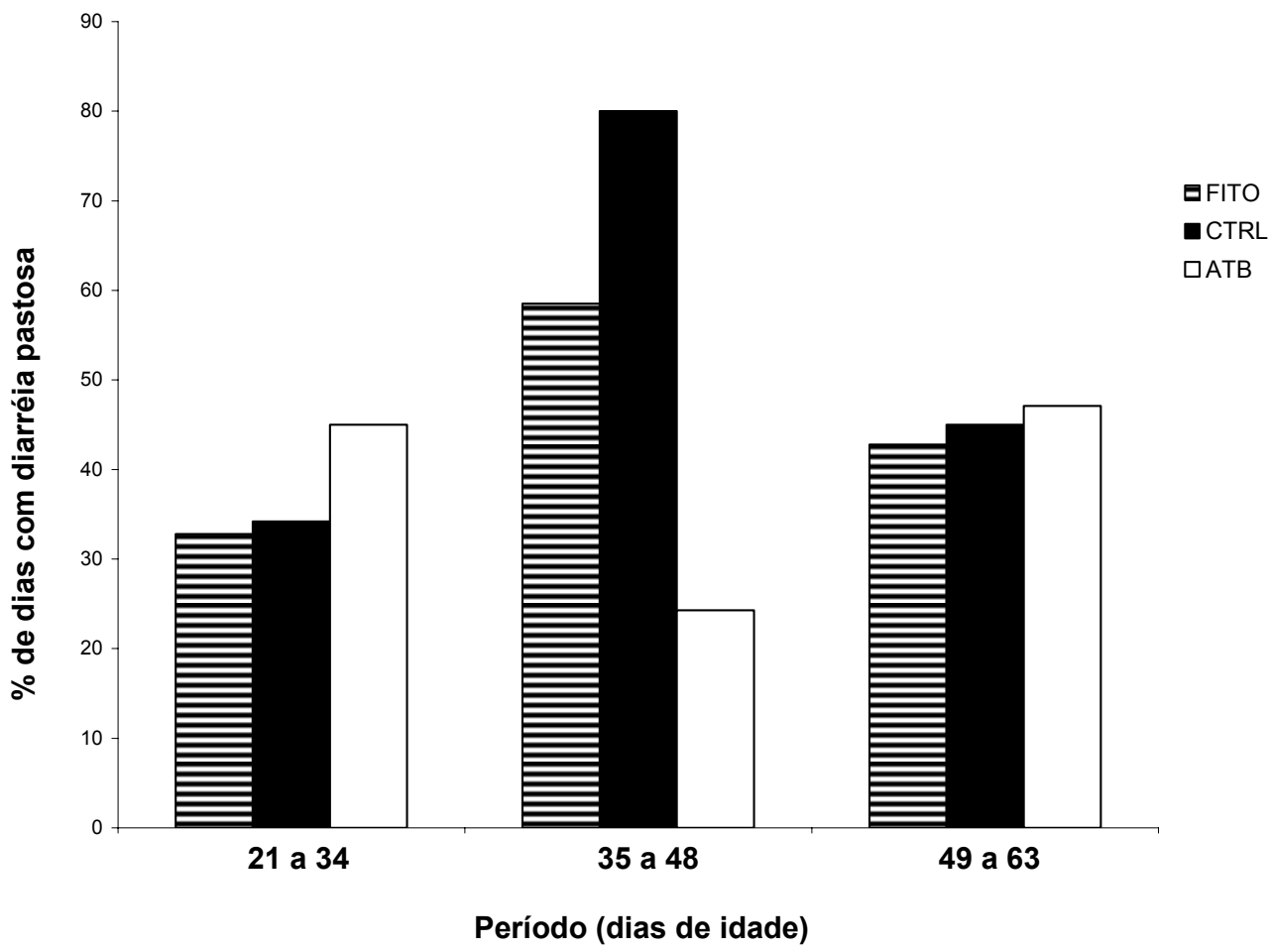

Figura 10 - Freqüência de dias com diarréia pastosa em leitões recebendo na ração fito composto (FITO), antibiótico (ATB) ou sem aditivos (CTRL) dos 21 aos 34, 35 aos 48 e dos 49 aos 63 dias de idade. Médias em cada período com letras diferentes diferem estatisticamente no teste de Tukey $(5 \%$ de significância) 
Tabela 17 - Valores médios e coeficiente de variação da freqüência de dias com diarréia pastosa (FDDp) de leitões dos 21 aos 34 , 35 aos 48, 49 aos 63 e 21 aos 63 dias de idade, recebendo na dieta fito composto (FITO), antibiótico (ATB) ou sem aditivo algum na dieta (CTRL), nas salas desafiadas (D) ou não desafiadas (SD)

\begin{tabular}{|c|c|c|c|c|c|c|c|c|}
\hline \multirow[b]{2}{*}{ Período } & \multirow[b]{2}{*}{ Sala } & \multicolumn{3}{|c|}{ Aditivos } & \multirow[b]{2}{*}{ Médias $^{2}$} & \multicolumn{3}{|c|}{$\mathbf{P}$} \\
\hline & & FITO & CTRL & ATB & & aditivo & sala & aditivo*sala \\
\hline \multirow[t]{2}{*}{21 a 34 dias } & $\mathrm{D}$ & 18,5 & 25,7 & 40,0 & $28,1^{B}$ & \multirow[t]{3}{*}{ ns } & \multirow[t]{3}{*}{0,034} & \multirow[t]{3}{*}{$\mathrm{ns}$} \\
\hline & SD & 47,1 & 42,8 & 50,0 & $46,6^{A}$ & & & \\
\hline Médias $^{1}$ & & 32,8 & 34,2 & 45,0 & & & & \\
\hline CV & & 50,0 & 46,9 & 172,1 & & & & \\
\hline \multirow[t]{2}{*}{35 a 48 dias } & $\mathrm{D}$ & $50,0^{a b A}$ & $65,7^{\mathrm{aB}}$ & $24,3^{b A}$ & 46,7 & \multirow[t]{3}{*}{$<0,0001$} & \multirow[t]{3}{*}{0,002} & \multirow[t]{3}{*}{0,025} \\
\hline & SD & 67,1 bA & $94,3^{\text {aA }}$ & $24,3^{\mathrm{cA}}$ & 61,9 & & & \\
\hline Médias $^{1}$ & & 58,5 & 80,0 & 24,3 & & & & \\
\hline CV & & 106,0 & 90,9 & 191,2 & & & & \\
\hline \multirow[t]{2}{*}{49 a 63 dias } & $\mathrm{D}$ & 37,1 & 32,8 & 42,8 & $37,6^{\mathrm{B}}$ & \multirow[t]{3}{*}{ ns } & \multirow[t]{3}{*}{0,002} & \multirow[t]{3}{*}{ ns } \\
\hline & SD & 48,6 & 57,16 & 51,4 & $52,3^{A}$ & & & \\
\hline Médias $^{1}$ & & 42,8 & 45,0 & 47,1 & & & & \\
\hline CV & & 129,5 & 110,5 & 161,1 & & & & \\
\hline \multirow[t]{2}{*}{21 a 63 dias } & $\mathrm{D}$ & 35,2 & 41,4 & 35,7 & 37,4 & \multirow[t]{3}{*}{ ns } & \multirow[t]{3}{*}{ ns } & \multirow[t]{3}{*}{ ns } \\
\hline & SD & 54,3 & 64,7 & 41,9 & 53,6 & & & \\
\hline Médias $^{1}$ & & 44,7 & 53,1 & 38,8 & & & & \\
\hline CV & & 62,7 & 51,0 & 154,4 & & & & \\
\hline
\end{tabular}

Médias seguidas de letras minúsculas diferentes na mesma linha ou de letras maiúsculas na mesma coluna diferem entre si pelo teste de Tukey ( $<<0,05)$.

Média ${ }^{1}$ : médias obtidas pelos diferentes aditivos.

Média ${ }^{2}$ : médias obtidas em cada sala.

P: probabilidades.

Ns: não significativo

CV (\%): Coeficiente de Variação. 


\subsubsection{Freqüência de dias com diarréia líquida (FDDI)}

A tabela 18 apresenta os valores médios das características relacionadas à freqüência de dias com diarréia líquida (FDD/) dos 21 aos 34, 35 aos 48 e 49 aos 63 dias de idade.

Pode-se notar que nas três quinzenas, a FDD/ é significativamente maior na sala desafiada (Figura 11), bem como durante todo o período de creche (dos 21 aos 63 dias, de acordo com a Tabela 18). Com relação ao efeito dos aditivos, tanto dos 21 aos 34 dias, quanto dos 35 aos 48 dias (Figura 12) e no período total de creche (21 aos 63 dias, Tabela 18), os leitões do grupo ATB apresentaram menor FDD/ que do grupo CTRL e FITO, não diferindo entre si estes dois grupos.

Dos 49 aos 63 dias é observado uma recuperação dos animais do grupo FITO e CTRL em relação ao grupo $A T B$, não havendo diferenças significativas quanto à FDDI entre eles (Figura 12). Essa tendência da não influência dos aditivos sobre a freqüência de dias com diarréia dos 49 aos 63 dias é observada também para a diarréia pastosa (Figura 10), e para a diarréia total (Figura 8). 


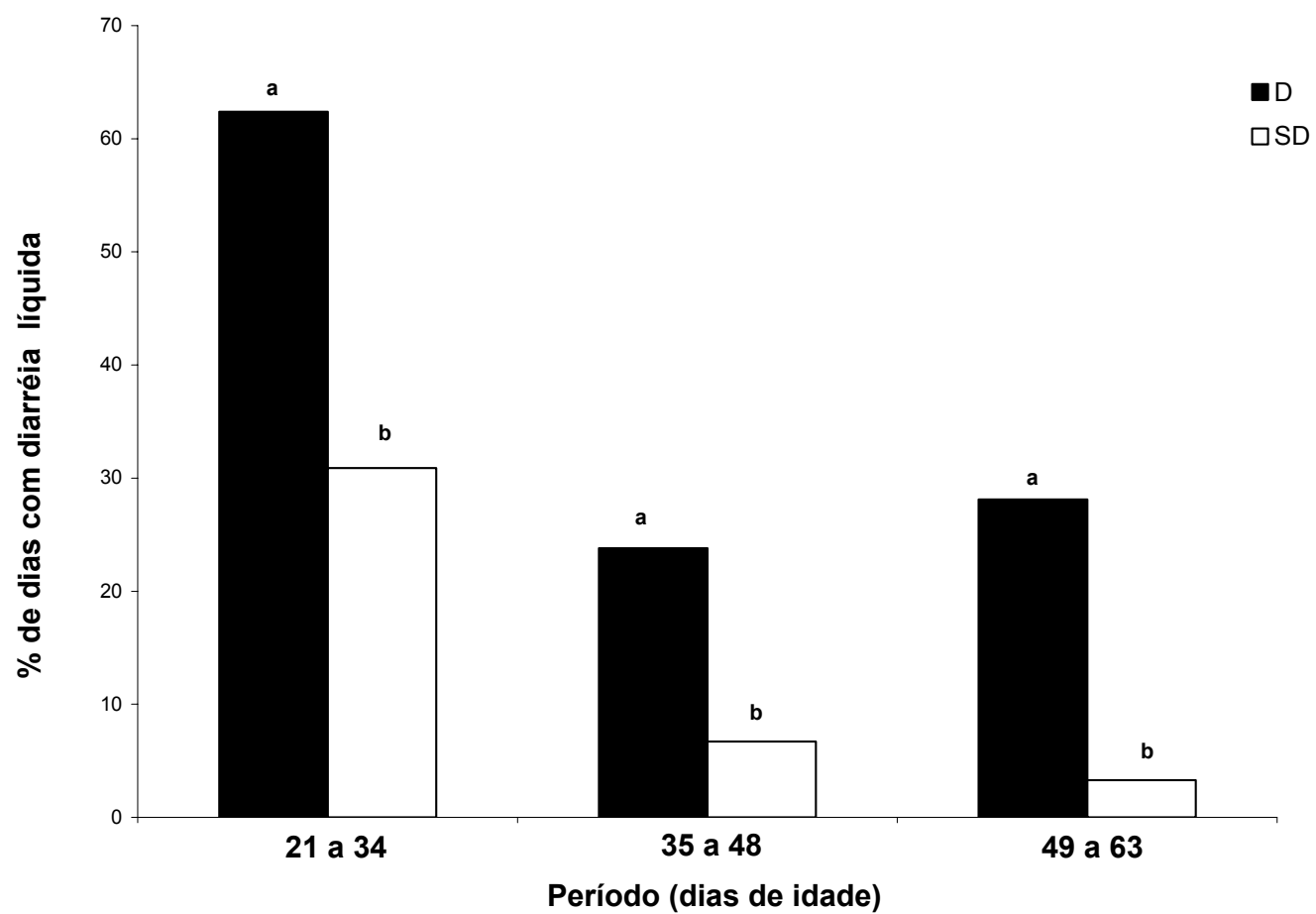

Figura 11 - Freqüência de dias com diarréia líquida nos leitões nas salas desafiadas (D) e sem desafio (SD), dos 21 aos 34, 35 aos 48 e dos 49 aos 63 dias de idade. Médias em cada período com letras diferentes diferem estatisticamente no teste de Tukey (5\% de significância) 


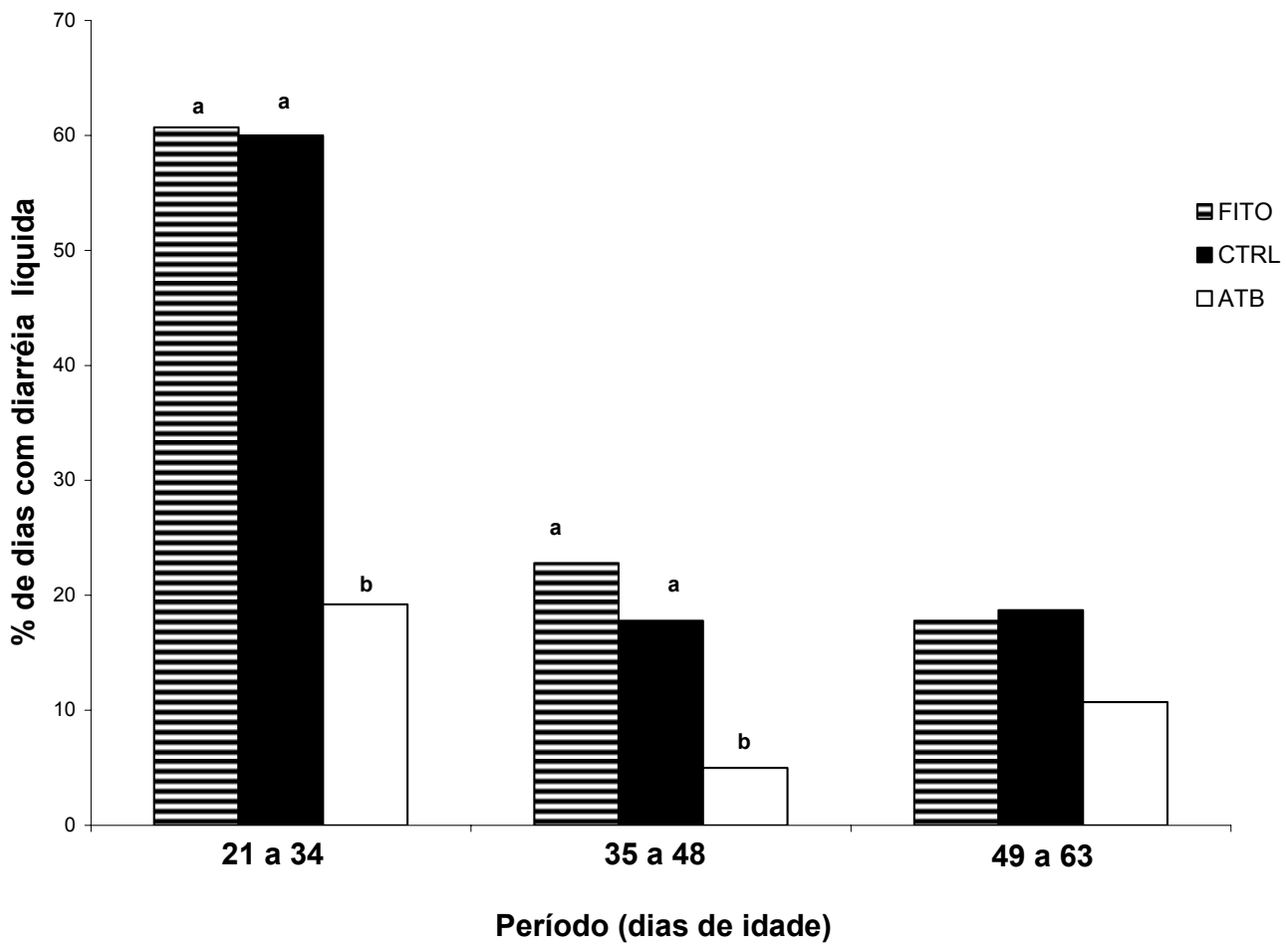

Figura 12 - Freqüência de dias com diarréia líquida em leitões recebendo na ração fito composto (FITO), antibiótico (ATB) ou sem aditivos (CTRL) dos 21 aos 34, 35 aos 48 e dos 49 aos 63 dias de idade. Médias em cada período com letras diferentes diferem estatisticamente no teste de Tukey (5\% de significância) 
Tabela 18 - Valores médios e coeficiente de variação da freqüência de dias com diarréia líquida (FDD/) de leitões dos 21 aos 34 , 35 aos 48, 49 aos 63 e 21 aos 63 dias de idade, recebendo na dieta fito composto (FITO), antibiótico (ATB) ou sem aditivo algum na dieta (CTRL), nas salas desafiadas (D) ou não desafiadas (SD)

\begin{tabular}{|c|c|c|c|c|c|c|c|c|}
\hline \multirow[b]{2}{*}{ Período } & \multirow[b]{2}{*}{ Sala } & \multicolumn{3}{|c|}{ Aditivos } & \multirow[b]{2}{*}{ Médias $^{2}$} & \multicolumn{3}{|c|}{$\mathbf{P}$} \\
\hline & & FITO & CTRL & ATB & & aditivo & sala & aditivo*sala \\
\hline \multirow[t]{2}{*}{21 a 34 dias } & $\mathrm{D}$ & 78,6 & 72,8 & 35,7 & $62,4^{A}$ & \multirow[t]{3}{*}{0,003} & \multirow[t]{3}{*}{0,005} & \multirow[t]{3}{*}{$\mathrm{ns}$} \\
\hline & SD & 42,8 & 47,1 & 2,84 & $30,9^{\mathrm{B}}$ & & & \\
\hline Médias $^{1}$ & & $60,7^{a}$ & $60,0^{a}$ & $19,2^{b}$ & & & & \\
\hline CV & & 76,8 & 64,2 & 57,4 & & & & \\
\hline \multirow[t]{2}{*}{35 a 48 dias } & $\mathrm{D}$ & 31,4 & 30,0 & 10,0 & $23,8^{A}$ & \multirow[t]{3}{*}{0,032} & \multirow[t]{3}{*}{0,003} & \multirow[t]{3}{*}{ ns } \\
\hline & SD & 14,3 & 5,7 & 0 & $6,7^{\mathrm{B}}$ & & & \\
\hline Médias $^{1}$ & & $22,8^{a}$ & $17,8^{a}$ & $5,0^{b}$ & & & & \\
\hline CV & & 34,8 & 22,6 & 42,1 & & & & \\
\hline \multirow[t]{2}{*}{49 a 63 dias } & $D$ & 35,7 & 28,6 & 20,0 & $28,1^{A}$ & \multirow[t]{3}{*}{ ns } & \multirow[t]{3}{*}{$<, 0001$} & \multirow[t]{3}{*}{ ns } \\
\hline & SD & 0 & 8,7 & 1,4 & $3,3^{\mathrm{B}}$ & & & \\
\hline Médias $^{1}$ & & 17,8 & 18,7 & 10,7 & & & & \\
\hline $\mathrm{CV}$ & & 78,5 & 43,6 & 71,4 & & & & \\
\hline \multirow[t]{2}{*}{21 a 63 dias } & $\mathrm{D}$ & 48,6 & 43,8 & 21,9 & $38,1^{A}$ & \multirow{3}{*}{0,0005} & \multirow[t]{3}{*}{$<, 0001$} & \multirow[t]{3}{*}{ ns } \\
\hline & SD & 19,0 & 20,6 & 1,4 & $13,6^{\mathrm{B}}$ & & & \\
\hline Médias $^{1}$ & & $33,8^{a}$ & $32,1^{a}$ & $11,6^{b}$ & & & & \\
\hline CV & & 34,5 & 27,8 & 39,1 & & & & \\
\hline
\end{tabular}

Médias seguidas de letras minúsculas diferentes na mesma linha ou de letras maiúsculas na mesma coluna diferem entre si pelo teste de Tukey $(P<0,05)$.

P: probabilidades.

Média': médias obtidas pelos diferentes aditivos.

Média²: médias obtidas em cada sala.

Ns: não significativo

CV (\%): Coeficiente de Variação. 


\subsection{ELIMINAÇÃO FECAL DE SALMONELLA TYPHIMURIUM}

A eliminação de Salmonella typhimurium foi avaliada através da colheita de fezes em suabes retais aos 35 (dia da inoculação), 49 e 63 dias de idade. Foi detectada a presença ou ausência da bactéria em cada animal, e o resultado foi dado em percentual de ocorrência (número de animais positivos dividido pelo número de animais em cada tratamento).

Não obstante a inoculação experimental ter ocorrido somente no dia 35, já neste dia haviam animais positivos para Salmonella typhimurium em amba as salas, o que indica que os animais já vieram contaminados da granja de origem. Nos três períodos considerados (35, 49 e 63 dias de idade) não houve diferenças entre as salas quanto à presença de salmonela (Tabela 19). As comparações entre os aditivos foram feitas duas a duas, dentro de cada sala, através do teste exato de Fisher. Na sala sem desafio, não houve diferenças significativas entre o grupo FITO e ATB, nem entre FITO e CTRL, em nenhuma das idades consideradas (Tabela 20). $\mathrm{Na}$ sala desafiada, no entanto, houve tendência a diferença entre FITO e ATB (Tabela 21), aos 63 dias de idade. A freqüência de eliminação de bactérias dos animais do grupo FITO foi numericamente menor que no grupo ATB (respectivamente, 0 vs $40 \%, p=0,08$ ).

Alguns pontos devem ser considerados: a baixa dose de salmonelas administrada aos animais ( $10^{5}$ u.f.c.); o fato dessas bactérias serem inoculadas apenas uma vez; a limpeza das baias ser realizada diariamente, o que pôde ter impedido a recontaminação dos animais e favorecer a baixa eliminação de bactérias pelas fezes (JOHNSON et al., 2005). Além disso, a metodologia de avaliação da eliminação de $S$. typhimurium utilizada no presente estudo perde um pouco a acurácia dado a uma limitação técnica, já que, devido à etapa de enriquecimento seletivo, a análise quantitativa (contagem de colônias bacterianas nas fezes) tornase impraticável, indicando apenas a presença ou ausência da bactéria nas fezes, de modo que, talvez, houvesse diferenças quanto à quantidade de bactérias eliminadas entre os tratamentos. Outra possível explicação para a não significância da diferença entre a eliminação fecal de bactérias entre os tratamentos ou entre as diferentes salas pode ter sido o intervalo de coleta de suabes, que no presente experimento foi quinzenal. Turner et al. (2002b) também não observaram diferenças significativas 
entre a eliminação de S. Typhimurium entre leitões recebendo ou não a inoculação experimental dessas bactérias (6 × $10^{9}$ u.f.c.) 14 dias após a inoculação; no entanto, na primeira semana após a inoculação, leitões do grupo inoculado eliminaram significativamente mais bactérias que o grupo não inoculado. Portanto, recomendase, em experimentos posteriores, diminuir o intervalo de entre as coleta de fezes. À semelhança de Turner et al. (2002a), não foi observada diminuição da eliminação fecal de S. typhimurium devido à administração de extratos herbáceos.

Tabela 19 - Freqüência observada da presença de Salmonella typhimurium em suabes retais de leitões aos 35, 49 e 63 dias de idade, na sala desafiada (D) e sem desafio (SD)

\begin{tabular}{lccc} 
& \multicolumn{3}{c}{ Dias de idade } \\
\cline { 2 - 4 } SALA & $\mathbf{3 5}$ & $\mathbf{4 9}$ & $\mathbf{6 3}$ \\
\hline $\mathrm{D}$ & $13,33 \%(4 / 30)$ & $20 \%(6 / 30)$ & $16,67 \%(5 / 30)$ \\
$\mathrm{SD}$ & $23,33 \%(7 / 30)$ & $26,67 \%(8 / 30)$ & $16,67 \%(5 / 30)$ \\
\hline $\mathrm{P}$ & $\mathrm{ns}$ & $\mathrm{ns}$ & $\mathrm{ns}$ \\
\hline $\mathrm{P}:$ probabilidade $($ Teste exato de Fisher $)$ & & \\
Ns: não significativo $(\mathrm{P}<0,05)$ & &
\end{tabular}

Tabela 20 - Freqüência observada da presença de Salmonella typhimurium em suabes retais de leitões aos 35, 49 e 63 dias de idade, tratados com fito composto (FITO), antibióticos (ATB) ou que não receberam aditivo na ração (CTRL), na sala desafiada

\begin{tabular}{lccc}
\hline & \multicolumn{3}{c}{ Dia de idade } \\
\cline { 2 - 4 } Aditivo & $\mathbf{3 5}$ & $\mathbf{4 9}$ & $\mathbf{6 3}$ \\
\hline ATB & $30 \%(3 / 10)$ & $10 \%(1 / 10)$ & $40 \%(4 / 10)$ \\
FITO & $0(0 / 10)$ & $40 \%(4 / 10)$ & $0(0 / 10)$ \\
CTRL & $10 \%(1 / 10)$ & $10 \%(1 / 10)$ & $10 \%(1 / 10)$ \\
\hline $\mathrm{P}^{*}$ & $\mathrm{~ns}$ & $\mathrm{~ns}$ & $\mathbf{0 , 0 8}$ \\
$\mathrm{P}^{* *}$ & $\mathrm{~ns}$ & $\mathrm{~ns}$ & $\mathrm{~ns}$ \\
\hline $\mathrm{P}^{* *}$ probabilidades FITO vs ATB (Teste exato de Fisher) & & \\
$\mathrm{P}^{* *}:$ probabilidades FITO vs CTRL (Teste exato de Fisher) & & \\
Ns: não significativo $(\mathrm{P}<0,05)$ & &
\end{tabular}


Tabela 21 - Freqüência observada da presença de Salmonella typhimurium em suabes retais de leitões aos 35, 49 e 63 dias de idade, tratados com fito composto (FITO), antibióticos (ATB) ou que não receberam aditivo na ração (CTRL), na sala não desafiada

\begin{tabular}{lccc}
\hline & \multicolumn{3}{c}{ Dia de idade } \\
\cline { 2 - 4 } Aditivo & $\mathbf{3 5}$ & $\mathbf{4 9}$ & $\mathbf{6 3}$ \\
\hline ATB & $30 \%(3 / 10)$ & $10 \%(1 / 10)$ & $20 \%(2 / 10)$ \\
FITO & $30 \%(3 / 10)$ & $30 \%(3 / 10)$ & $20 \%(2 / 10)$ \\
CTRL & $10 \%(1 / 10)$ & $40 \%(4 / 10)$ & $10 \%(1 / 10)$ \\
\hline $\mathrm{P}^{*}$ & $\mathrm{~ns}$ & $\mathrm{~ns}$ & $\mathrm{~ns}$ \\
$\mathrm{P}^{* *}$ & $\mathrm{~ns}$ & $\mathrm{~ns}$ & $\mathrm{~ns}$ \\
\hline $\mathrm{P}^{*}$ : probabilidades FITO vs ATB (Teste exato de Fisher) & & \\
$\mathrm{P}^{* *}:$ probabilidades FITO vs CTRL (Teste exato de Fisher) & & \\
Ns: não significativo (P<0,05) &
\end{tabular}

\subsection{HISTOPATOLOGIA DO TRATO GASTROINTESTINAL}

O exame histopatológico dos fragmentos de íleo, cólon e linfonodo mesentérico de animais abatidos tanto aos 21 dias de idade quanto aos 63 dias, mostrou lesões correspondentes a ação da $S$. typhimurium. Foi realizada também a comparação dos escores de lesão histológica entre os tratamentos FITO e CTRL, e FITO e ATB, dentro de cada sala. A tabela 22 indica os graus de cada lesão histopatológica com os respectivos escores atribuídos. A tabela 23 indica o escore de cada lesão nos diferentes tratamentos. Não houve efeito significativo, apenas uma tendência à significância $(p=0,08)$ dentro da sala desafiada, para as seguintes lesões: edema de submucosa no íleo (FITO menor que ATB); infiltrado polimorfonuclear predominante na submucosa do cólon (FITO maior que CTRL). Na sala sem desafio, também houve tendência à significância $(p=0,08)$ para as seguintes lesões: inflitrado polimorfonuclear predominante na lâmina própria do íleo (FITO maior que CTRL) e inflitrado mononuclear predominante na submucosa e lâmina própria do cólon (CTRL maior que FITO). As lesões que não apresentaram diferenças significativas foram omitidas. As figuras 13 e 14 são fotos tiradas respectivamente do íleo e cólon de leitões do presente experimento, e mostram inflitrados leucocitários. Com relação ao infiltrado de leucócitos, em nenhum caso foi encontrado maiores valores para o tratamento ATB, em relação ao FITO, o que pode decorrer da ação de cada um desses aditivos. Um dos mecanismos de ação dos fitoterápicos é o aumento da atividade funcional de fagócitos, enquanto que os antibióticos agem exclusivamente sobre a bactéria, diminuindo a inflamação no local. 
Essa ação de FITO pode ter potencializado a presença local de fagócitos mononucleares (monócitos ou macrófagos) ou polimorfonucleares (neutrófilos e eosinófilos) no intestino dos leitões que receberam esse aditivo, apesar desses resultados serem conflitantes, pois vários autores reportaram a diminuição da produção de quimiocinas (moléculas responsáveis pela atração de fagócitos no local da inflamação) em função da ação de ervas medicinais (SETTY; SIGAL, 2005; CONSENTINO et al., 2008), enquanto outros (CORREAA et al., 2006) relatam ação dos fitoterápicos sobre a ativação dos fagócitos não em virtude de aumento local no número dessas células, mas sim levando a uma maior produção de ânions superóxidos e conseqüentemente melhorando sua atividade fagocítica. Outros autores também relataram diminuição da espessura da mucosa ileal e infiltrado de monócitos e macrófagos nessa região, em função da ação de antimicrobianos, em aves mantidas em ambientes com alto nível de contaminação (ROURA et al., 1992).

Manzanilla et al. (2006) observaram menores quantidades de linfócitos intraepiteliais no íleo e jejuno de leitões recém-desmamados, em virtude da adição de extratos de plantas medicinais à ração, em relação a animais não suplementados. Como os linfócitos presentes no epitélio são egressos da lâmina própria, este estudo também mostra que os extratos vegetais diminuem a migração dessas células pelo intestino, seja por diminuição da presença bacteriana no local ou por diminuição da atividade imune.

Apesar de não ser encontrado diferenças significativas em nenhuma lesão pesquisada, do ponto de vista descritivo algumas observações foram feitas, com base na tabela 23. De acordo com os graus atribuídos a cada lesão (Tabela 22), nota-se que, na sala desafiada, há uma tendência ao aparecimento de hiperplasia de criptas no íleo, que vai de um grau moderado ao acentuado. Nota-se, ainda, que nesta sala, há maior intensidade de infiltrados de polimorfonucleares, e que há tendência ao aparecimento de edema em um grau moderado, no íleo dos animais que receberam antimicrobiano (ATB), enquanto nos animais que receberam o fito composto (FITO), esse edema tende a estar presente em um grau moderado. Ainda, a análise histológica dos linfonodos mesentéricos revela que houve uma tendência ao aparecimento de hiperplasia folicular em um grau mais intenso nos animais desafiados, e que essa resposta foi mais intensa nos leitões recebendo ATB. Em conjunto essas observações qualitativas sugerem que, por um lado, houve maior resposta inflamatória nos animais alocados na sala desafiada, e que nestes, houve uma tendência do tratamento FITO amenizar essa resposta inflamatória em relação à ATB. 
Tabela 22 - Escore atribuído e respectivo grau de lesão histológica

\begin{tabular}{cc}
\hline Escore atribuído & Grau de lesão \\
\hline 0 & Ausente \\
1 & Leve \\
2 & Moderado \\
3 & Acentuado \\
\hline
\end{tabular}


Tabela 23 - Escore de cada lesão no íleo, cólon e linfonodo mesentérico nas salas desafiadas (D) e sem desafio (SD), em 12 leitões $\left(L_{1}\right.$ a $\left.L_{12}\right)$ de 63 dias de idade recebendo o fitocomposto (FITO), antibióticos (ATB) ou não recebendo aditivos (CTRL) na dieta

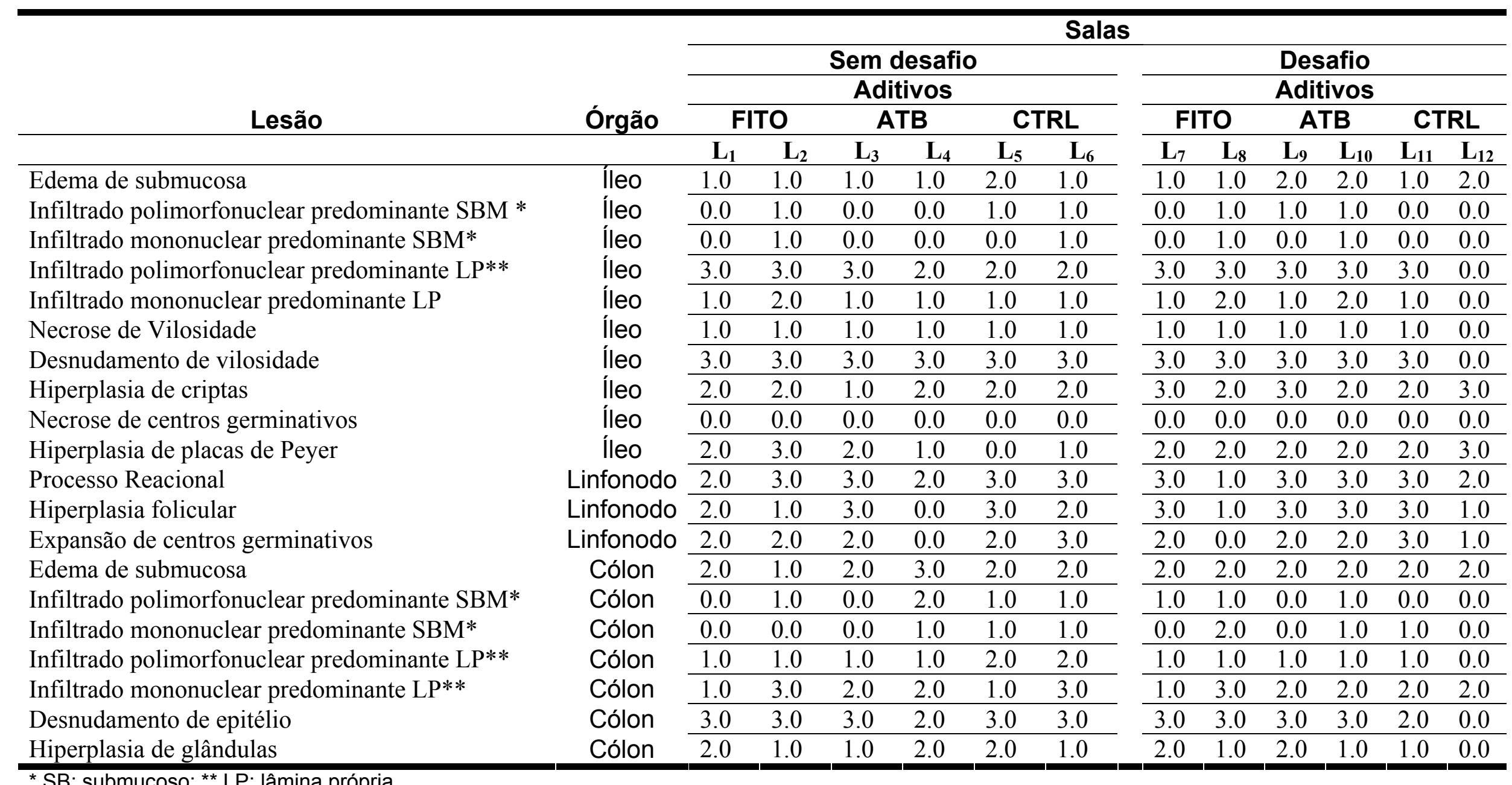

\section{* SB: submucoso; ** LP: lâmina própria}




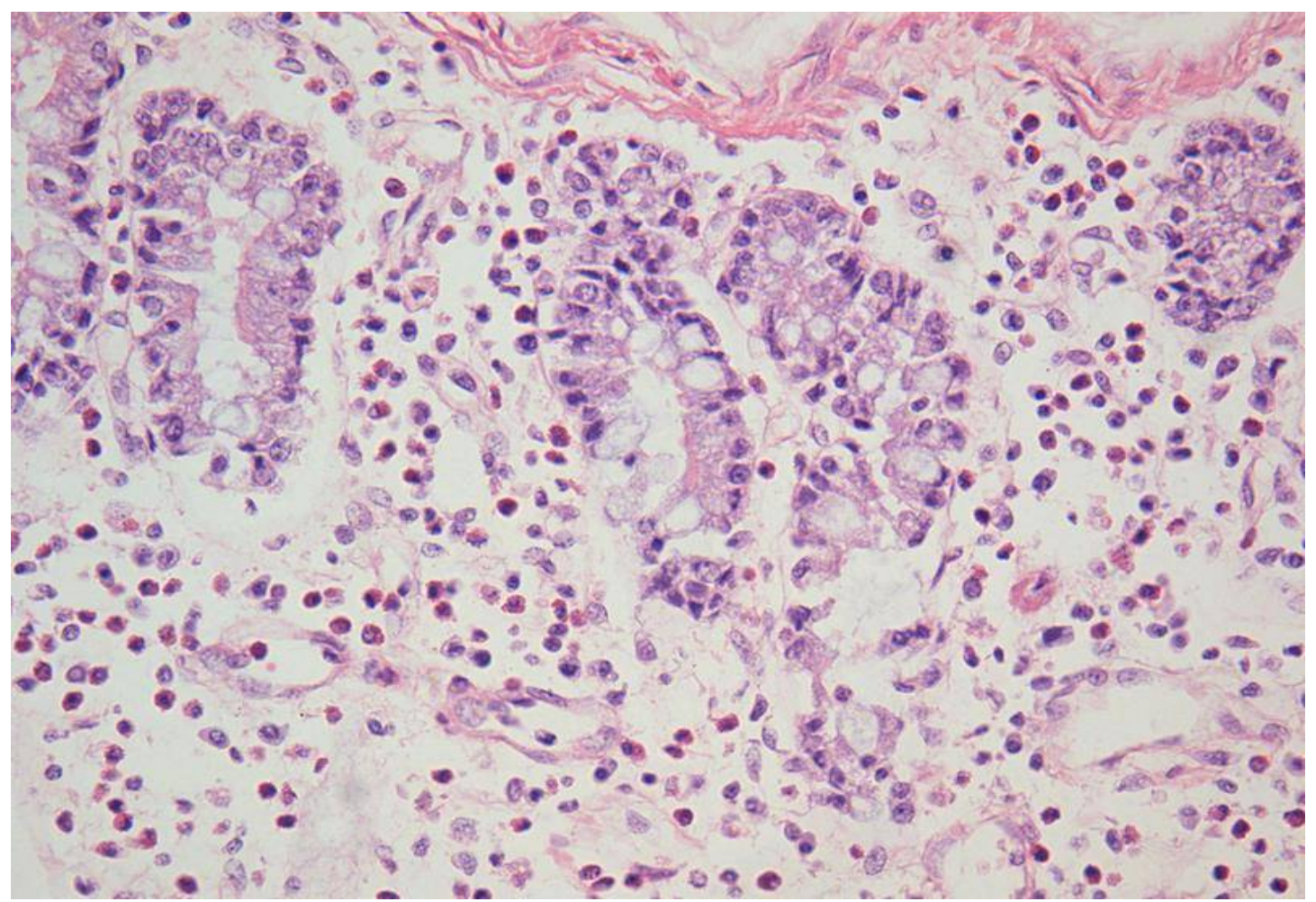

Figura 13 - Região das criptas no íleo com infiltrado predominantemente neutrofílico na lâmina própria - HxE, aumento de 400 vezes

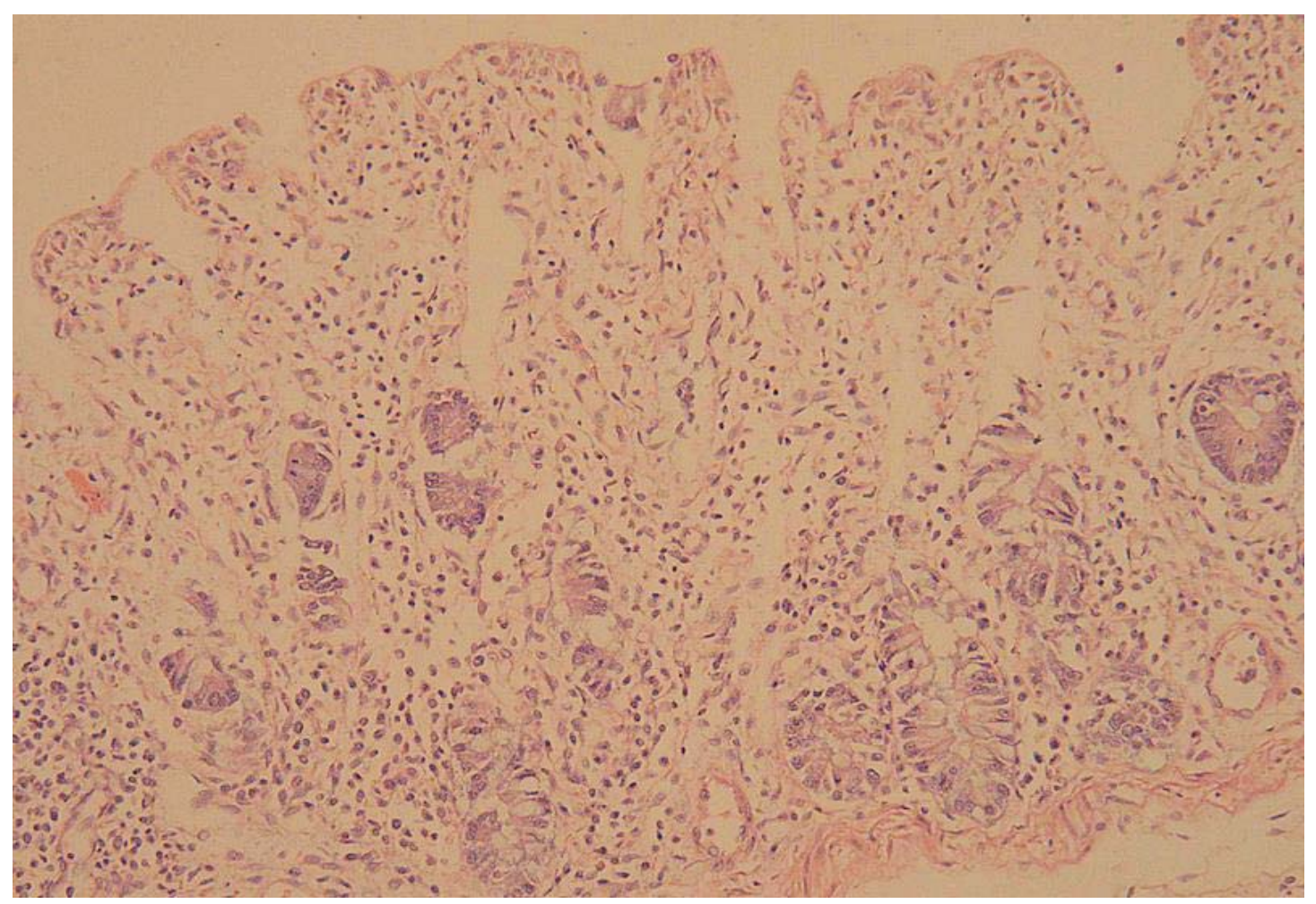

Figura 14 - Cólon com desnudamento do epitélio superficial e manutenção das glândulas. Presença de infiltrado leucocitário moderado em lâmina própria - HxE, aumento de 100 vezes 


\subsection{ANÁLISE DA ESTABILIDADE OXIDATIVA DA GORDURA INTRAMUSCULAR}

A concentração média de malonaldeído no tecido muscular foi mensurada nos leitões alocados na sala não desafiada durante a creche e está representada na figura 15. Essa substância indica o grau de oxidação da gordura muscular, de modo que quanto maior a quantidade de malondialdeído por $\mathrm{kg}$ de músculo, menor é a resistência dessa carne à oxidação. O processo de rancidez oxidativa, ou peroxidação lipídica é a principal causa de perda de qualidade do alimento ou da ração, afetando seu sabor, aroma, cor e textura, além de resultar em um sério decréscimo no seu valor nutritivo (SCOTT et al., 1982).

Apesar de, numericamente, a concentração média de malonaldeído de FITO e ATB serem semelhantes, e ambas numericamente superiores à concentração no grupo CTRL, esses valores não foram significativos, havendo somente indicação de efeito. Portanto, numericamente, a gordura intramuscular de animais alocados no grupo CTRL apresenta maior estabilidade à oxidação lipídica. Esses resultados divergem de vários outros estudos. Vários autores reportaram atividade antioxidante de compostos originários de ervas medicinais administrados via oral para animais, especialmente os polifenóis (MORENO et al., 2006), que seriam absorvidos pela corrente sangüínea durante a digestão e se acumulariam na carne, oferecendo maior estabilidade oxidativa e com isso aumentando o tempo de prateleira do produto. Contrariamente ao presente estudo, Jans et al. (2007) reportaram tendência a maior estabilidade oxidativa de suínos alimentados com óleos essenciais de orégano, em relação ao grupo controle não suplementado, apesar dessa diferença ser meramente numérica. Origanum vulgare e Rosmarinus officinalis são as principais plantas medicinais pesquisadas com relação à atividade antioxidante na carne, e vários autores observaram melhora neste parâmetro após suplementação dessas ervas na dieta de frangos (BOTSOGLOU et al., 2002; BASMACIOUGLOU et al., 2004), perus (GOVARIS et al., 2007) e coelhos (BOTSOGLOU et al., 2004), contrariamente ao presente estudo.

Existe uma relação bem estabelecida entre os valores médios de TBARS e as 
avaliações sensoriais de carne (BOU et al., 2001). De acordo com Olivo e Shimokomaki (2002), produtos cárneos com índices de TBARS menores que 1,0 $\mathrm{mg} / \mathrm{kg}$, geralmente não apresentam sabores e odores residuais de ranço característicos de oxidação lipídica. Já Galvin et al. (1997) afirmam que "off-flavours" podem ser detectados em carnes oxidadas a partir de valores de TBARS entre 0,500 e 2,00 mg/kg de carne. Assim, os resultados de TBARS do presente estudo indicam que não houve alterações sensoriais nem em FITO, CTRL e ATB. Outro fato interessante de ser notado é que no tratamento ATB, a variabilidade foi maior que em CTRL e FITO, conforme a figura 15. Os valores dos desvios-padrões dos três aditivos foram iguais a 0,13 (ATB), 0,01 (FITO) e 0,02 (CTRL).

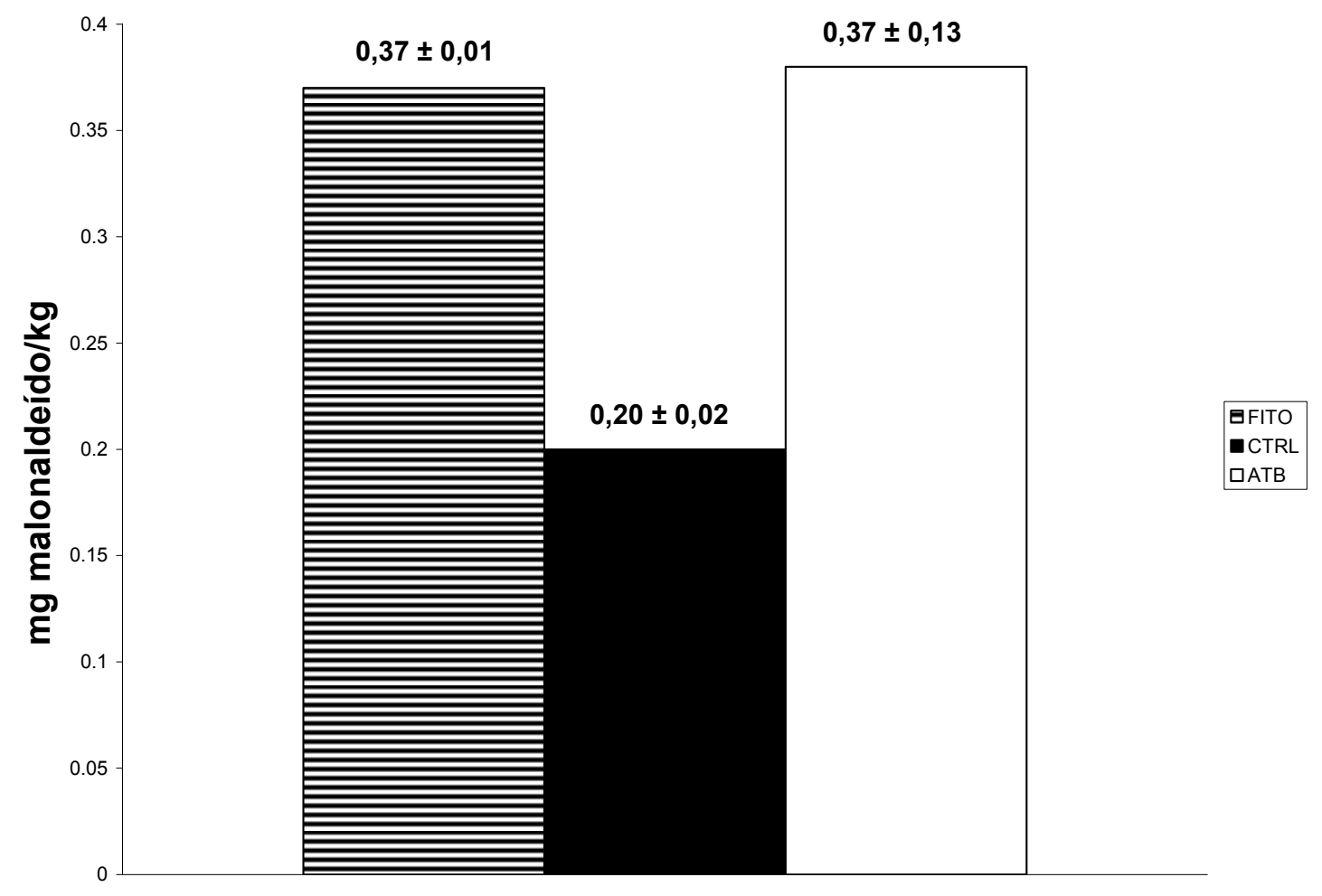

Figura 15 - Valores médios e desvio-padrão da concentração de malonaldeído ( $\mathrm{mg} / \mathrm{kg}$ de tecido muscular) nos leitões recebendo o fito composto (FITO), antimicrobianos (ATB) ou não suplementados (CTRL) 


\section{CONCLUSÕES}




\section{CONCLUSÕES}

O estudo do efeito de aditivos como promotores de crescimento em leitões desafiados ou não experimentalmente, revelou aspectos interativos interessantes para justificar ações específicas do antimicrobiano e de ervas naturais na alimentação de leitões. Assim sendo, a pesquisa revelou quanto ao peso médio dos animais uma superação do antibiótico em relação ao fito composto durante toda a fase de creche e guase toda de crescimento e terminação, não havendo diferença na idade final de terminação, aos 131 dias de idade dos leitões. Essa semelhança foi devido a um ganho de peso diferencial em favor do fito composto principalmente no final do crescimento, dos 96 aos 105 dias de idade e particularmente no desafio, indicando um efeito compensatório em relação ao antibiótico. A conversão alimentar não diferenciada entre os tratamentos indicou um efeito do Fito no aproveitamento mais eficiente do alimento, no período de crescimento e terminação mas particularmente na fase final de crescimento e justamente em leitões desafiados. A inoculação por Salmonella typhimurium levou à queda aguda no consumo alimentar, na primeira quinzena. A freqüência de diarréia foi menos acentuada no antibiótico e no fito em comparação a não suplementação logo após desafio, igualando-se entre si uma quinzena após. Não houve influência dos tratamentos sobre a eliminação fecal de salmonelas, nem sobre as lesões histopatológicas causadas pela bactéria no íleo, cólon e linfonodo mesentérico, apenas efeito sugestivo de ação imunomodulatória do fitocomposto. Não houve diferença entre os três aditivos sobre a oxidação lipídica dos animais suplementados. Assim, a melhor conversão alimentar na creche em relação à não suplementação, bem como a melhora no desempenho em animais submetidos a desafio em etapas posteriores e a menor freqüência de diarréia na segunda quinzena de creche sugerem que a ação do fito composto seja mais tardia em relação aos antibióticos, justificando maiores pesquisas com essas ervas. 
REFERÊNCIAS 


\section{REFERÊNCIAS}

ABREU-MATTOS, F. J. Plantas medicinais: guia de seleção e emprego de plantas usadas em fitoterapia no Nordeste do Brasil. 2. ed. fortaleza, CE: Imprensa Universitária-UFC, 2000, 346 p.

ACAMOVIC, T.; BROOKER, J. D. Biochemistry of plant secondary metabolites and their effects in animals. Proceedings of the Nutrition Society, v. 64, p. 403-412, 2005.

AL-SEREITI, M. R.; ABU-AMER, K. M.; SEN, P. Pharmacology of rosemary (Rosmarinus officinalis Linn.) and its therapeutic potentials. Indian Journal of Experimental Biology, v. 37, p. 124-130, 1999.

ALÇIÇEK, A.; BOZKURT, M.; ÇABUK, M. The effect of an essential oil combination derived from selected herbs growing wild in Turkey on broiler performance. South African Journal of Animal Science, v. 33, n. 2, p. 89-94, 2003.

ALÇIÇEK, A.; BOZKURT, M.; ÇABUK, M. The effect of a mixture of herbal essential oils, an organic acid or a probiotic on broiler performance. South African Journal of Animal Science, v. 34, n. 4, p. 217-222, 2004.

ALLAN, P.; BILKEI, G. Oregano improves reproductive performance of sows. Theriogenology, v. 63, p. 716-721, 2005.

ANDRIGHETTO, J. M.; PERLY, L.; MINARDI, I.; FLEMMING, J. S.; GEMAEL, A.; 
SOUZA, G.A.; FILHO, A. B. Nutrição Animal. São Paulo: Nobel, 1983. v. 2, 425 p.

BALAJI, R.; WRIGHT, K. J.; HILL, C. M.; DRITZ, S. S.; KNOPPEL, E. L.; MINTON, J. E. Acute phase responses of pigs challenged orally with Salmonella typhimurium. Journal of Animal Science, v. 78, p. 1885-1891, 2000.

BAMPIDIS, V. A.; CHRISTODOULOU, V.; FLOROU-PANERI, P.; CHRISTAKI, E. Effect of dried oregano leaves versus neomycin in treating newborn calves with colibacilosis. Journal of Veterinary Medicine Series A: Physiology Pathology Clinical Medicine, v. 53, p. 154-156, 2006.

BAMPIDIS, V. A.; CHRISTODOULOU, V.; FLOROU-PANERI, P.; CHRISTAKI, E.; SPAIS, A. B.; CHATZOPOULOU, P. S. Effect of dietary dried oregano leaves supplementation on performance and carcass characteristics of growing lambs. Animal Feed Science and Technology, v. 121, p. 285-295, 2005a.

BAMPIDIS, V. A.; CHRISTODOULOU, V.; FLOROU-PANERI, P.; CHRISTAKI, E.; CHATZOPOULOU, P. S.; TSILIGIANNI, T.; SPAIS, A.B. Effect of dietary dried oregano on growth performance, carcase characteristics and serum cholesterol of female early maturing turkeys. Britsh Poultry Science, v. 46, n. 5, p. 595-601, 2005b.

BANZATTO, D. A.; KRONKA, S. N. Experimentação agrícola. Jaboticabal: Funep, 1989, 247 p.

BARBIN, D. Planejamento e análise estatística de experimentos agropecuários. Arapongas: Midas, 2003. 194 p. 
BARTON-DAVIS, E. R.; SHOTURMA, D. I.; MUSARO, A.; ROSENTHAL, N.; SWEENEY, H. L. Viral mediated expression of insulin-like growth factor I blocks the aging-related loss of skeletal muscle function. Proceedings of the National Academy of Science of USA, v. 95, p. 15603-15607, 1998.

BASMACIOGLOU, H; TOKUSOGLOU, Ö.; ERGÜL, M. The effect of orégano and rosemary essential oils or alpha-tocopheryl acetate on performance and lipid oxidation of meat enriched with n-3 PUFA's in broilers. South African Journal of Animal Science, v. 34, n. 3, p. 197-210, 2004.

BOERLIN, P.; WISSING, A.; AARESTRUP, F. M.; FREY, J.; NICOLET, J. Antimicrobial growth promoter ban and resistence to macrolides and vancomycin in enterococci from pigs. Journal of Clinical Microbiology, v. 39, n. 11, p. 4193-4195. 2001.

BOTSOGLOU, N. A.; FLOROU-PANERI P.; CHRISTAKI E.; FLETOURIS D. J.; SPAIS, A.B. Effect of dietary oregano essential oil on performance of chickens and on iron-induced lipid oxidation of breast, thigh and abdominal fat tissues. Britsh Poultry Science, v. 43, n. 2, p. 223-230, 2002.

BOTSOGLOU, N. A.; FLOROU-PANERI, P.; CHRISTAKI, E.; GIANNENAS, I.; SPAIS, A. B. Performance of rabbits and oxidative stability of muscle tissues as affected by dietary supplementation with oregano essential oil. Archives of Animal Nutrition, v. 58, n. 3, p. $209-218,2004$.

BOTSOGLOU, N. A.; FLOROU-PANERI P.; NIKOLAKAKIS, I.; GIANNENAS, I.; DOTAS, V.; BOTSOGLOU, E. N.; AGGELOPOULOS, S. Effect of dietary saffron (Crocus sativus L.) on the oxidative stability of egg yolk. British Poultry Science, v. 
36, n. 6, p. 701-707, 2005.

BOU, R.; GUARDIOLA, F.; GRAU, A,; GRIMPA, S.; MANICH, A.; BARROETA, A.; CODONY, R. Influence of dietary fat source, $\alpha$-tocopherol, and ascorbic acid supplementation on sensory quality of dark chicken meat. Poultry Science, v. 80, p. 800-807, 2001.

BOYRAZ, N.; OZCAN, M. Antifungal effect of some spice hydrosols. Fitoterapia, v. 76, n. 7-8, p. 661-665, 2005.

BROUSSARD, S.; ZHOU, J. H. ; VENTERS, H. D.; BLUTHE, R. M.; FREUND, G. G.; JOHNSON, R. W.; DANTZER, R.; KELLEY, K. W. At the interface of environment-immune interactions: cytokines and growth-factor receptors. Journal of Animal Science, v. 79, p. E268-E284, 2001.

BRUGALLI, I. Alimentação alternativa: a utilização de fitoterápicos ou nutracêuticos como moduladores da imunidade e desempenho animal. In: SIMPÓSIO SOBRE MANEJO E NUTRIÇÃO DE AVES E SUÍNOS, 2003, Campinas. Anais... Campinas: CNBA, 2003. p. 167-182.

BUDDLE, J. R.; BOLTON, J. R. The pathophysiology of diarrhoea in pigs. Pig News Inf.ormation, v. 13, p. 41-45, 1992.

BURT, S. Essentail oils: their antibacterial properties and potencial applications in foods - a review. International Journal of Food Microbiology, v. 94, p. 223-253, 2004. 
CALICH, V.; VAZ, C. Imunologia. Rio de Janeiro: Revinter, 2001. 260 p.

CARVAlHo, A. F.; MELO, V. M.; CRAVEIRO, A. A.; MACHADO, M. I.; BANTIM, M. B.; RABELO, E. F. Larvicidal activity of the essential oil from Lippia sidoides Cham. Against Aedes aegypti linn. Memórias do Instituto Oswaldo Cruz, v. 98, n. 4 p. 569-571, 2003.

CHRYSIS, D.; UNDERWOOD, L. E. Regulation of components of the ubiquitin system by insulin-like growth factor I and growth hormone in skeletal muscle of rats made catabolic with dexamethasone. Endocrinology, v. 140, p. 5635-5641, 1999.

COSENTINO, M.; BOMBELLI, R.; CARCANO, E.; LUINI, A.; MARINO, F.; CREMA, F.; DAJAS, F.; LECCHINI, S. Immunomodulatory properties of Achyrocline satureioides (Lam.) D.C. infusion: A study on human leukocytes. Journal of Ethnopharmacology, v. 116, n. 3, p. 501-507, 2008.

COSTA, S. M.; LEMOS, T. L.; PESSOA, O. D.; PESSOA, C.; MONTENEGRO, R. C.; BRAZ-FILHO, R. Chemical constituents from Lippia sidoides and cytotoxic activity. Journal of Natural Products, v. 64, n. 6, p. 792-795, 2001.

CORRÊA, V. S. C.; MAYNIÉ, J. C.; FRANÇA, E. L.; HONÓRIO-FRANÇA, A. C. Atividade funcional de fagócitos na presença do fitoterápico "Mais Vida". Revista Brasileira de Plantas Medicinais, v. 8, n. 2, p. 26-32, 2006.

COSTA, L. B.; TSE, M. L. P.; GARCIA, A. N.; BRAZ, D. B.; ALMEIDA, V. V.; MIYADA, V. S. Substituição de antimicrobianos por extratos vegetais em dietas de leitões recém-desmamados. In:CONGRESSO LATINO-AMERICANO DE SUINOCULTURA, 3., 2006, Foz do Iguaçu, PR. Anais... Concórdia: Embrapa 
Suínos e Aves, 2006. v. 3, p. 705-707.

COWAN, M. M. Plant products as antimicrobial agents. Clinical Microbiology Review, v. 12, n. 4, p. 564-582. 1999.

DEBERSAC P.; HEYDEL, J. M.; AMIOT, M. J.; GOUDONNET, H.; ARTUR, Y.; SUSCHETET, M.; SIESS, M. H. Induction of cytochrome P450 and/or detoxication enzymes by various extracts of rosemary: description of specific patterns. Food and Chemical Toxicology, v. 39, n. 9, p. 907-918, 2001.

DEL-BAÑO, J. M.; LORENTE, J.; CASTILLO, J.; BENAVENTE-GARCÍA, O.; MARÍN, M.P.; del RÍO, J. A.; ORTUÑO, A.; IBARRA, I. Flavonoid distribution during the development of leaves, flowers, stems, and roots of rosmarinus officinalis. postulation of a biosynthetic pathway. Journal of Agricultural end Food Chemistry, v. 52, p. 4987-4992, 2004.

DENLI, M.; OKAN, F.; ULUOCAK, A. N. Effect of dietary supplementation of herb essential oils on the growth performance, carcass and intestinal characteristics of quail (Coturnix coturnix japonica). South African Journal of Animal Science, v. 34, n. 3, p. $174-179,2004$

DEWICK, P. M. Medicinal natural products: a biosynthetic approach. West Sussex: John Wiley \& Sons, 1998. 466 p.

DI PASQUA, R.; HOSKINS, N.; BETTS, G.; MAURIELLO, G. Changes in membrane fatty acids composition of microbial cells induced by addiction of thymol, carvacrol, limonene, cinnamaldehyde, and eugenol in the growing media. Journal of Agricultural and Food Chemistry, v. 54, p. 2745-2749, 2006. 
DUARTE, M. C.; FIGUEIRA, G. M.; SARTORATTO, A.; REHDER, V. L.; DELARMELINA, C. Anti-Candida activity of Brazilian medicinal plants. Journal of Ethnopharmacology,v. 97, n. 2, p. 305-311, 2005.

ESCOBAR, J.; VAN ALSTINE, W. G.; BAKER, D. H.; JOHNSON, R. W. Decreased Protein Accretion in Pigs with Viral and Bacterial Pneumonia Is Associated with Increased Myostatin Expression in Muscle. The Journal of Nutrition, v. 134, n. 11, p. 3047-3053, 2004.

ESTEVEZ, M.; VENTANAS, S.; RAMIREZ, R.; CAVA, R. Influence of the addition of rosemary essential oil on the volatiles pattern of porcine frankfurters. Journal of Agricultural and Food Chemistry, v. 53, n. 21, p. 8317-8324, 2005.

FERREIRA, A. A.; AZEVEDO, A. O.; SILVEIRA, D.; OlIVEIRA, P. M.; CSTRO, M.S.A.; RASLAN, D.S. Constituents of Lychnophora pinaster hydroalcoholic extract. Chemestry of natural Compounds, v. 41, n. 4, p. 466, 2005.

FINCK, B. N.; JOHNSON, R. W. Tumor necrosis factor-alpha regulates secretion of the adipocyte-derived cytokine, leptin. Microscopy Research and Technology, v. 50, p. 209-215, 2000.

FOURNIER, P. Le Livre dês Plantes Médicinales et vénéneuses de France. 3 ed, Paris:Editions Lachevalier, p.335-336, 1948.

FRASER, J. N.; DAVIS, B. L.; SKJOLAAS, K. A.; BURKEY, T. E.; DRITZ, S. S.; JOHNSON, B. J.; MINTON, J. E. Effects of feeding Salmonella enterica serovar 
Typhimurium or serovar Choleraesuis on growth performance and circulating insulinlike growth factor-I, tumor necrosis factor- $\alpha$, and interleukin- $1 \beta$ in weaned pigs. Journal of Animal Science, v. 85, p. 1161-1167, 2007.

FUKAYAMA, E. H.; BERTECHINI, A. G.; GERALDO, A.; KATO, R. K.; MURGAS, L. D. S. Extratos de orégano como aditivos em rações de frangos de corte. Revista Brasileira de Zootecnia, v. 34, n. 6, p. 2316-2326, 2005. Supplement.

GALVIN, K.; MORRISSEY, P. A.; BUCKLEY, D. J. Influence of dietary vitamin E and oxidized sunflower oil on the storage stability of cooked chicken muscle. British Poultry Science, v. 38, p. 499-501, 1997.

GIANNENAS, I. ; FLOROU-PANERI, P.; PAPAZAHARIADOU, M.; CHRISTAKI, E.; BOTSOGLOU, N. A.; SPAIS, A. B. Effect of dietary supplementation with Oregano essential oil on performance of Broilers after experimental infection with Eimeria tenella. Archives of Animal Nutrition, v. 57, n. 2, p. 99-106, 2003.

GIRÃO, V. C.; NUNES-PINHEIRO, D. C.; MORAIS, S. M.; SEQUEIRA, J. L.; GIOSO, M. A. A clinical trial of the effect of a mouth-rinse prepared with Lippia sidoides Cham essential oil in dogs with mild gingival disease. Preventive Veterinary Medicine., v. 59, n. 1-2, p. 95-102, 2003.

GOVARIS, A.; FLOROU-PANERI, P.; BOTSOGLOU, E.; GIANNENAS, I.; AMVROSIADIS, I.; BOTSOGLOU, N. The inhibitory potential of feed supplementation with rosemary and/or a-tocopheryl acetate on microbial growth and lipid oxidation of turkey breast during refrigerated storage. LWT-Food Science and Technology, v. 40, p. 331-337, 2007. 
GUARRERA, P. M. Traditional phytotherapy in Central Italy (Marche, Abruzzo, and Latium). Fitoterapia, v. 76, n. 1, p. 1-25, 2005.

GUO, F. C.; KWAKKEL, R. P.; SOEDE, J.; WILLIAMS, B. A.; VERSTEGEN, M. W. A. Effect of a Chinese herb medicine formulation, as an alternative for antibiotics, on performance of broilers. British Poultry Science, v. 45, n. 6, p. 793-797, 2004.

HAUPTLI, L.; LOVATTO, P. A.; HAUSCHILD, L. Comparação da adição de extratos vegetais e antimicrobianos sintéticos para leitões na creche através de meta-análise. Ciência Rural, v. 37, n. 4, p. 1084-1090, 2007.

HERNÁNDEZ, F.; MADRD, J.; GARCÍA, V.; ORENGO, J.; MEGIAS, M. D. Influence of two plants extracts on broiles performance, digestibility, and digestive organ size. Poultry Science, v. 83, p. 169-174, 2004.

HEDEMANN, M. S.; JENSEN, B. B. Variations in enzyme activity in stomach and pancreatic tissue and digesta in piglets around weaning. Archives of Animal Nutrition, v. 58, n. 1, p. 47-59, 2004.

HELANDER, I. K.; ALAKOMI, H. L.; LATVA-KALA, K.; MATTILA-SANDHOLM, T.; POL, I.; SMID, E. J.; GORRIS, L. G. M.; VON WRIGHT, A. Characterization of the action of Selected essential oil components on Gram-negative bacteria. Journal of Agricultural end Food Chemistry, v. 46, p. 3590-3595, 1998.

HOEFLER, C.; FleURENTIN, J.; MORTIER, F.; PELT, J. M.; GUILLEMAIN, J. Comparative choleretic and hepatoprotective properties of young sprouts and total plant extracts of Rosmarinus officinalis in rats. Journal of Ethnopharmacology, $v$. 19 , n. 2, p. 133-143,1987. 
HOLCK, J. T.; SCHINKEL, A. P.; COLEMAN, J. L.; WILT, V. M.; SEEN, M. K.; THACKER, B. J.; THACKER, E. L.; GRANT, A. L. The influence of environment on the growth of commercial finisher pigs. Swine Health and Production, v. 6, n. 4, p. 141-149, 1998.

HOLT, J. G.; KRIEG. N. R.; SNEATH, P. H.; STANLEY, J. T. Bergey's Manual of Determinative bacteriology. 9 th edn. Baltimore: Williams \& Wilkins, 1994. p. 175189.

INOUE, T.; SUGIMOTO, Y.; MASUDA, H.; KAMEI, C. Effects of peppermint (Mentha piperita L.) extracts on experimental allergic rhinitis in rats. Biological \& Pharmaceutical Bulletin, v. 24, n. 1, p. 92-95, 2001.

İSCAN, G.; KIRIMER, N.; KURKCUOGLU, M.; BASER, K. H.; DEMIRCI, F. Antimicrobial screening of Mentha piperita essential oils. Journal of Agricultural and Food chemistry, v. 50, n. 14, p. 3943-3946, 2002.

JOHNSON, B. J.; DRITZ, S. S.; SKJOLAAS-WILSON, K. A.; BURKEY, T. E.; MINTON, J. E. Interactive responses in gut immunity, and systemic and local changes in the insulin-like growth factor system in nursery pigs in response to Salmonella enterica serovar Typhimurium. Journal of Animal Science, v. 83, p. E48-E56, 2005. Supplement, E.

JUGL-CHIZZOLA, M.; UNGERHOFER, E.; GABLER, C.; HAGMULLER, W.; CHIZZOLA, R.; ZITTERL-EGLSEER, K.; FRANZ, C. Testing of the palatability of Thymus vulgaris $L$. and Origanum vulgare $L$. as flavouring feed additive for weaner pigs on the basis of a choice experiment. Berliner und Munchener Tierarztliche Wochenschrift, v. 119, n. 5-6, p. 238-243, 2006. 
JANZ, J. A. M.; MOREL, P. C. H.; WILKINSONPURCHAS, B. H. P.; PURCHAS, R. W. Preliminary investigation of the effects of low-level dietary inclusion of fragrant essential oils and oleoresins on pig performance and pork quality. Meat Science, v. 75, p. 350-355, 2007.

KABOUCHE, Z.; BOUTAGHANE, N.; LAGGOUNE, S.; KABOUCHE, A.; AIT-KAKI, Z.; BENLABED, K. Comparative antibacterial activity of five Laminaceae essential oils from Algeria. The International Journal of Aromatherapy, v. 15, p. 129-133, 2005.

KLASING, K. C. Interactions between nutrition and immunity. In: SWINE CONFERENCE, 21., 1994, St. Paul. Proceedings... St. Paul: University of Minnesota, 1994. v. 21, p. 35-39.

LAMBERT, R. J.; SKANDMIS, P. N.; COOTE, P. J.; NYCHAS, G. J. A study of the minimum inhibitory concentration and mode of action of oregano essential oil, thymol and carvacrol. Journal of Applied Microbiology, v. 91, n. 3, p. 453-462, 2001.

LEAL, P. F.; BRAGA, M. E.; SATO, D. N.; CARVALHO, J.E.; MARQUES, M.O.; MEIRELES, M.A..Functional properties of spice extracts obtained via supercritical fluid extraction. Journal of Agricultural and Food Chemistry, v. 51, n. 9, p. 25202525, 2003.

LEMOS, T. L. G.; MATOS, F. J. A.; ALENCAR, J. W.; CRAVEIRO, A. A.; CLARK, A. M.; MCCHESNEY, J. D. Antimicrobial activity of essential oils of Brazilian plants. Phytotherapy Research, v. 4, n. 2, p. 82-84, 1990. 
LEE, K. W.; EVERTS, H.; KAPPERT, H. J.; FREHNER, M.; LOSA, R.; BEYNEN, A. C. Effects of dietary essential oil components on growth performance, digestive enzymes and lipid metabolism in female broiler chickens. British Poultry Science, v. 44, n. 3, p. 450-457, 2003.

LETCHAMO, W.; WARD, W.; HEARD, B.; HEARD, D. Essential Oil of Valeriana officinalis L. Cultivars and their antimicrobial activity as influenced by harvesting time under commercial organic cultivation. Journal of Agricultural end Food Chemistry, v. 52, p. 3915-3919, 2004.

LIMA, G. J. M. M.; RUTZ, F.; BORGES, S. A.; VIOLA, E. S. Efeito da adição de um composto de ervas naturais como promotor de crescimento em dietas de suínos em crescimento e terminação. In: CONGRESSO BRASILEIRO DE VETERINÁRIOS ESPECIALISTAS EM SUÍNOS, 10., 2001, Porto Alegre, RS. Anais... Porto Alegre: Associação Brasileira de Veterinários Especialistas em Suínos, 2005. v. 2. p. 398399.

LIN, Y. T.; LABBE, R. G.; SHETTY, K. Inhibition of Listeria monocytogenes in fish and meat systems by use of oregano and cranberry phytochemical synergies. Applied and Environmental Microbiology, v. 70, n. 9, p. 5672-5678, 2004.

LIS-BALCHIN, M.; HART, S. Studies on the mode of action of peppermint oil Mentha $x$ piperita L. in the guinea-pig ileum in vitro. Medical Science Research, v. 27, p. 307-309, 1999.

LOVATTO, P. A.; OLIVEIRA, V.; HAUSCHILD, L. Alimentação de leitões na creche com dietas sem aditivos antimicrobianos, com alho (Allium sativum, L.) ou colistina. Ciência Rural, v. 35, n. 3, p. 656-659, 2005. 
LULE, S. U.; XIA, W. Food phenolics, pros and cons: a review. Food Reviews International, v. 21, p. 367-388, 2005.

MAASS, N.; BAUER, J.; PAULICKS, B. R.; BÖHMER, B. M.; ROTH-MAIER, D. A. Efficiency of Echinacea purpurea on performance and immune status in pigs. Journal of Animal Physiology and Animal Nutrition, v. 89, p. 244-252, 2005.

MANZANILLA, E. G.; NOFRARÍAS, M.; ANGUITA, M.; CASTILLO, M.; PEREZ, J. F.; MARTÍN-ORÚE, S. M.; KAMEL, C.; GASA, J. Effects of butyrate, avilamycin, and plant extract combination on the intestinal equilibrium of early-weaned pigs. Journal of Animal Science, v. 84, p. 2743-2751, 2006.

MARION, J.; ROMÉ, V.; SAVARY, G.; THOMAS, F.; LE DIVIDICH, J.; LE HUEROULURON, I. Weaning and feed intake alter pancreatic enzyme activities and corresponding mRNA levels in 7-d-old piglets . Journal of Nutrition, v. 133, n. 2, p. 362-368, 2003.

MARTINS, S. M. M. K.; ALMEIDA, E.; MICHELONE, P. C.; VIANNA, W. L.; ABRAHÃO, A. A. F.; FERREIRA, L. A.; CAMAROTE, R. F.; MORETTI, A. S. Adição de um composto de ervas naturais na dieta de suínos na fase de crescimento e terminação. In: CONGRESSO BRASILEIRO DE VETERINÁRIOS ESPECIALISTAS EM SUÍNOS, 12., 2005, Fortaleza, CE. Anais... Fortaleza: Associação Brasileira de Veterinários Especialistas em Suínos, 2005. v. 2. p. 398-399.

ITO, N. M. K.; MIYAJI, C. I.; LIMA, E. A.; OKABAYASHI, S. Saúde Gastrointestinal, manejo e medidas para controlar as enfermidades gastrointestinais. In: MENDES, A.A.; NÄÄS, I.A.; MACARI, M. Produção de frangos de corte. Campinas: FACTA, 
2004. p. 205-260.

MAHAN, D. C.; LEPINE, A. J. Effect of pig weaning weight and associated nursery feeding programs on subsequent performance to $105 \mathrm{~kg}$ body weight. Journal of Animal Science, v. 69, p. 1370-1375, 1991.

MIMICA-DUKÏC, N.; BOZIN, B.; SOKOVIC, M.; MIHAJLOVIC, B.; MATAVULJ, M. Antimicrobial and antioxidant activities of three Mentha species essential oils. Planta Medica, v. 69, n. 5, p. 413-419, 2003.

MORENO, S.; SCHEYER, T.; ROMANO, C. S.; VOJNOV, A. A. Antioxidant and antimicrobial activities of rosemary extracts linked to their polyphenol composition. Free Radical Research, v. 40, n. 2, p. 223-231, 2006.

MONTAGNE, L.; BOUNDRY, G.; FAVIER, C.; LE HUEROU-LURON, I.; LALLÈS, J.P.; SÈVE, B. A. Main intestinal markers associated with the changes in gut architecture and function in piglets after weaning. British Journal of Nutrition, v. 97, n. 1, p. 45-57, 2007.

NABUURS, M. J. A.; HOOGENDOORN, A.; VAN DER MOLEN, E. J.; VAN OSTA, A. L. M. Villus height and crypt depth in weaned and unweaned pigs, reared under various circumstances in the Netherlands. Research in Veterinary Science, v. 55, p. $78-84,1993$.

NAMKUNG, H.; LI, M.; GONG, J.; YU, H.; COTTRILL, M.; LANGE, C. F. M. Impact of feeding blends of organic acids and herbal extracts on growth performance, gut microbiota and digestive function in newly weaned pigs. Canadian Journal of Animal Science, v. 84, p. 697-704, 2004. 
NASCIMENTO, G. F. G.; LOCATELLI, J.; FREITAS, P. C.; SILVA, G. L. Antibacterial activity of plants extracts and phytochemicals on antibiotic-resistant bacteria. Brazilian Journal of Microbiology, v. 31, p .247-256, 2000.

OETTING, L. L. Extratos vegetais como promotores do crescimento de leitões recém-desmamados. 2005. 66 f. Tese (Doutorado em Ciência Animal e pastagens) - Escola Superior de Agricultura "Luis de Queiroz", Universidade de São Paulo, Piracicaba, 2005.

OLIVO, R.; SHIMOKOMAKI, M. Carnes:no caminho da pesquisa. 2.ed. Cacoal do Sul: Imprint, 2002. 155 p.

OLUWATUYI, M.; KAATZ, G. W.; GIBBONS, S. Antibacterial and resistance modifying activity of Rosmarinus officinalis. Phytochemistry, v. 65 , n. 24, p. 32493254, 2004.

OUSSALAH, M.; CAILLET, S.; LACROIX, M. Mechanism of Action of Spanish Oregano, Chinese Cinnamon, and Savory Essential Oils against Cell Membranes and Walls of Escherichia coli 0157:H7 and Listeria monocytogenes. Journal of Food Protection, v. 69, n. 5, p. 1046-1055, 2006.

PEDROSO, A. A.; OETTING, L. L.; UTIYAMA, C. E.; MENTEN, J. F. M.; LAMBAIS, M. R.; MIYADA, V. S. Variabilidade espacial da comunidade bacteriana intestinal de suínos suplementados com antibióticos ou extratos herbais. Revista Brasileira de Zootecnia, v. 34, n. 4, p. 1225-1233, 2005. 
PENGELLY, A. The constituents of medical plants. 2. ed. Wallingford, UK: CABI Publising, 2004. 172 p.

PERRY, N. P.; ANDERSON, R. E.; BRENNAN, N. J.; DOUGLAS, M. H.; HEANEY, A. J.; MCGIMPSEY, J. A.; SMALLFIELD, B. M. Essential oils from dalmatian sage (Salvia officinalis I.):variations among individuals, plant parts, seasons, and sites. Journal of Agricultural end Food Chemistry, v. 47, p. 2048-2054, 1999.

POHLITI , A. M.; PINTO, A. C. S.; MACARI, P.Comparação da atividade antioxidante de 4-nerolidilcatecol, catecol e derivados acetilados. In: RESEM, 26., 2004, Niterói, RJ. Resumos... 2004. p.2.

QUINN, P. J.; CARTER, M. E.; MARKEY, B. K.; CARTER, G. R. Clinical veterinary microbiology. London: Wolfe Publishing, 1994. 648 p.

ROURA, E.; HOMEDES, J.; KLASING, K. C. Prevention of immunologic stress contributes to the growth-permitting ability of dietary antibiotics in chicks. Journal of Nutrition, v. 122, n. 12, p. 2383-2390, 1992.

SAMARTH, R. M; PANWAR, M.; KUMAR, M.; KUMAR, A. Protective effects of Mentha piperita Linn on benzo[a]pyrene-induced lung carcinogenicity and mutagenicity in Swiss albino mice. Mutagenesis, v. 21, n.1, p. 61-66, 2006.

SCOTT, M. L.; NESHEIN, M. C.; YOUNG, R. J. Nutrition of the chicken. 3. ed. Ithaca: M.L. SCOTT \& Associates, 1982. 562 p. 
STATISTICAL ANALISYS SYSTEM. SAS user's guide: statistics. Versão 5. Cary: SAS, 2001.

SCHÖNE, F.; VETTER, A.; HARTUNG, H.; BERGMANN, H.; BIERTÜMPFEL, A.; RICHTER, G.; MÜLLER, S.; BREITSCHUH, G. Effects of essential oils from fennel (Foeniculi aetheroleum) and caraway (Carvi aetheroleum) in pigs. Journal of Animal Physiology and Animal Nutrition, v. 90, p. 500-510, 2006.

SETTY, A. R.; SIGAL, L. H. Herbal medications commonly used in the practice of rheumatology: mechanisms of action, efficacy and side effects. Seminars in Arthritis and Rheumatism, v. 34, n. 6, p. 773-784, 2005.

SI, W.; GONG, J.; TSAO, R.; ZHOU, T.; YU, H.; POPPE, C.; JOHNSON, R.; DU, Z. Antimicrobial activity of essential oils and structurally related synthetic food additives towards selected pathogenic and beneficial gut bacteria. Journal of Applied Microbiology, v. 100, p. 296-305, 2006.

SPELMAN, K.; BURNS, J. J.; NICHOLS, D.; WINTERS, N.; OTTERSBERG, S.; TENBORG, M. Modulation of cytokine expression by traditional medicines: a review of herbal immunomodulators. Alternative Medicine Review. v. 11, n.2, p. 128-150, 2006.

SPINOSA, H. S.; GÓRNIAK, S. L.; BERNARDI, M. M. Farmacologia aplicada à medicina veterinária. 3. ed. Rio de Janeiro, RJ: Guanabara-koogan, 2002. 768 p.

STOLL, B. X.; CHANG, X.; FAN, M. Z.; REEDS, P. J.; BURRIN, D. G. Enteral nutrient intake determines the rate of intestinal protein synthesis and accretion in neonatal pigs. The American Journal of Physiology, v. 279, p. 49-57, 2000. 
STONE, G. G.; OBERST, R. D.; HAYS, M. P.; MCVEY, S.; CHENGAPPA, M. M. Detection of Salmonella serovars from clinical samples by enrichment broth cultivation-PCR procedure. Journal of Clinical Microbiology, v. 32, p. 1742-1749, 1994.

THRELFALL, E. J.; FROST, J. A.; ROWE, B. Public health problems associated with the use of antibiotics. In: GARNSWORTHY, P. C.; WISEMAN, J.; HARESIGN, W. Recent advances in animal nutrition. Nottingham: Nottingham University Press, 1996, p. 47-53.

TROMBETTA, D.; CASTELLI, F.; SARPIETRO, M. G.; VENUTI, V.; CRISTANI, M.; DANIELE, C.; SAIJA, A.; MAZZANTI, G.; BISIGNANO, G. Mechanisms of antibacterial action of three monoterpenes. Antimicrobial Agents and Chemotherapy, v. 49, n. 6, p. 2474-2478, 2005.

TURNER, J. L.; DRITZ, S. S.; HIGGINS, J. J.; HERKELMAN, K. L.; MINTON, J. E. Effects of a Quillaja saponaria extract on growth performance and immune function of weanling pigs challenged with Salmonella typhimurium. Journal of Animal Science, v. 80 , p. $1939-1946,2002 a$.

TURNER, J. L.; DRITZ, S. S.; HIGGINS, J. J.; MINTON, J. E. Effects of Ascophyllum nodosum extract on growth performance and immune function of young pigs challenged with Salmonella typhimurium. Journal of Animal Science, v. 80, p. 1947-1953, 2002b.

USHIDA, K.; MAEKAWA, M.; ARAKAWA, T. Influence of dietary supplementation of 
herbs extracts on volatile sulfur production in pig large intestine. Journal of Nutritional Science and Vitaminology, v. 48, n. 1, p. 18-23, 2002.

UTIYAMA, C. E. Utilização de agentes antimicrobianos, probióticos, prebióticos e extratos vegetais como promotores do crescimento em leitões recémdesmamados. 2004. 94 f. Tese (Doutorado em Ciência Animal e pastagens) Escola Superior de Agricultura "Luis de Queiroz", Universidade de São Paulo, Piracicaba, 2004.

ULTEE, A.; KETS, E. P. W.; SMID, E. J. Mechanisms of Action of Carvacrol on the Food-Borne Pathogen Bacillus cereus. Applied And Environmental Microbiology, v. 65 , n. 10, p. 4606-4610, 1999.

VARREL, V. H.; MILLER, D. L. Eugenol stimulates lactate accumulation yet inhibits volatile fatty acid production and eliminates coliform bacteria in cattle and swine waste. Journal of Applied Microbiology, v. 97, p. 1001-1005, 2004.

VENTE-SPREEUWENBERG, M. A.M.; BEYNEN, A.C. Diet-mediated modulation of small intestinal integrity in weaned piglets. In: PLUSKE, J.R.; LE DIVIDICH, J.; VERSTEGEN, M.W.A. Weaning the Pig: Concepts and Consequences. Wageningen: Wageningen Academic Publisher, p.145-199, 2003.

VENTE-SPREEUWENBERG, M. A. M.; VERDONK, J. M. A. J.; BAKKER, G. C. M.; BEYNEN, A. C.; VERSTEGEN, M. W. A. Effect of dietary protein source on feed intake and small intestinal morphology in newly weaned piglets. Livestock Production Science, v. 86, n. 1-3, p.169-177, 2004.

VYNCKE, W. Direct determination of thiobarbituric acid value in trichloroacetic 
extracts of fish as a measure of oxidative rancidity. Fette-Seinfen Anstrichmitel, v .72 , n. 12, p. 1084-1087, 1970.

WENK, C. Herbs and Botanicals as Feed Additives in Monogastric Animals. AsianAustralian Journal of Animal Science, v. 16, n. 2, p. 282-289, 2003.

ZHANG, K. Y.; YAN, F.; KEEN, C. A.; WALDROUP, P. W. Evaluation of microencapsulated essential oils and organic acids in diets for broiler chickens. International Journal of Poultry Science, v. 4, n. 9, p. 612-619, 2005. 